\title{
Archeological Testing of the Engstrand Well 41WM1157, in Williamson County, Texas
}

Bradford Jones

Rachel Feit

Follow this and additional works at: https://scholarworks.sfasu.edu/ita

Part of the American Material Culture Commons, Archaeological Anthropology Commons, Environmental Studies Commons, Other American Studies Commons, Other Arts and Humanities Commons, Other History of Art, Architecture, and Archaeology Commons, and the United States History Commons

Tell us how this article helped you.

This Article is brought to you for free and open access by the Center for Regional Heritage Research at SFA ScholarWorks. It has been accepted for inclusion in Index of Texas Archaeology: Open Access Gray Literature from the Lone Star State by an authorized editor of SFA ScholarWorks. For more information, please contact cdsscholarworks@sfasu.edu. 


\section{Archeological Testing of the Engstrand Well 41WM1157, in Williamson County, Texas}

\section{Licensing Statement}

This is a work for hire produced for the Texas Department of Transportation (TxDOT), which owns all rights, title, and interest in and to all data and other information developed for this project under its contract with the report producer. The report may be cited and brief passages from this publication may be reproduced without permission provided that credit is given to TxDOT and the firm that produced it. Permission to reprint an entire chapter, section, figures or tables must be obtained in advance from the Supervisor of the Archeological Studies Branch, Environmental Affairs Division, Texas Department of Transportation, 125 East 11th Street, Austin, Texas, 78701. 


\title{
Archeological Testing of the Engstrand Well 41WM1157, in Williamson County, Texas
}

\author{
Principal Investigator: \\ James W. Karbula \\ Written by: \\ Bradford Jones and Rachel Feit \\ Prepared for:
}

Texas Department of Transportation—Environmental Affairs Division

CSJ: 0204-01-049

TAC Permit \# 4347

TxDOT Archeological Studies Program No. 100

Archeology Series No. 190

October 2007
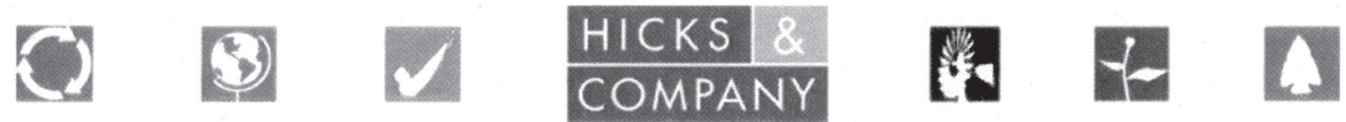

ENVIRONMENTAL

ARCHEOLOGICAL

AND PLANNING

CONSULTANTS 
Archeological Testing of the Engstrand Well, 41WM1157, in Williamson County, Texas

Copyright (C) 2007

Texas Department of Transportation and

Hicks \& Company Environmental, Archeological and Planning Consultants

All rights reserved. The Texas Department of Transportation (TxDOT) and Hicks \& Company (H\&C) jointly own all rights, title, and interest in and to all data and other information developed for this project under TxDOT Scientific Services Contract No. 577XXSA0006. Brief passages from this publication may be reproduced without permission provided that credit is given to TxDOT and Hicks \& Company. Permission to reprint an entire chapter, section, figures, or tables must be obtained in advance from the Supervisor of the Archeological Studies Program, Environmental Affairs Division, TxDOT, 118 East Riverside Drive, Austin, Texas, 78752. Copies of this publication have been deposited with the Texas State Library in compliance with the State Depository requirements.

Printed in the United States of America
in Austin, Texas by Morgan Printing

October 2007

Jointly published by:

Texas Department of Transportation

Environmental Affairs Division

Archeological Studies Program

Scott Pletka, Ph.D., Supervisor

Archeological Studies Program Report No. 100

Al McGraw, Series Editor

and

Hicks \& Company Environmental, Archeological and Planning Consultants 1504 West Fifth Street

Austin, Texas 78703

Cover Art by: Mason Miller

Texas Antiquities Permit Number 4347

ISBN 1-930788-69-X 


\section{Table of Contents}

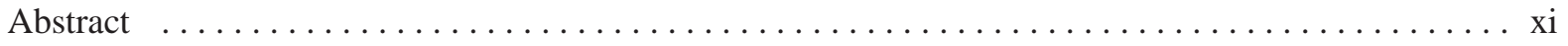

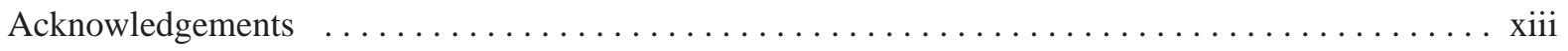

Chapter 1. Introduction and Management Summary $\ldots \ldots \ldots \ldots \ldots \ldots \ldots \ldots \ldots \ldots \ldots \ldots \ldots \ldots \ldots \ldots \ldots$

Chapter 2. Historical Background and Previous Archeological Investigations $\ldots \ldots \ldots \ldots \ldots \ldots \ldots 4$

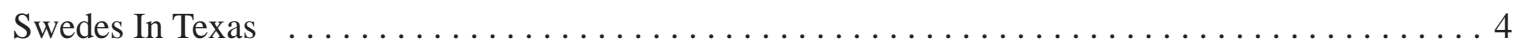

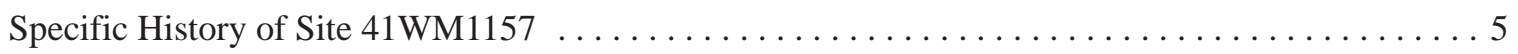

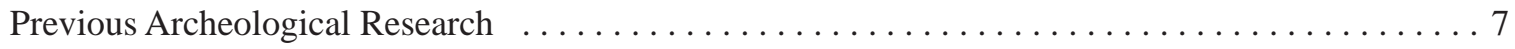

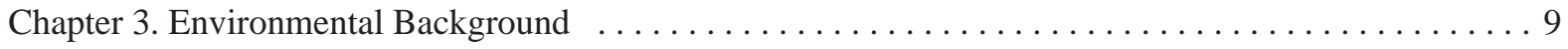

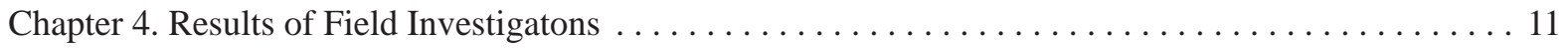

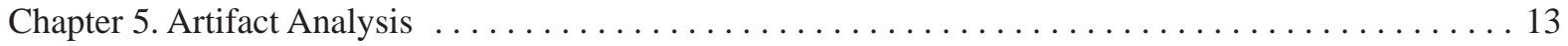

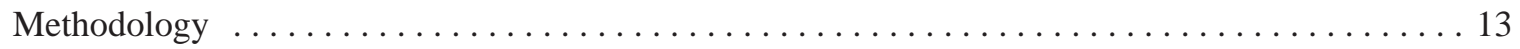

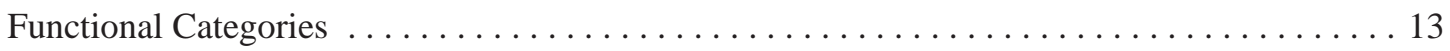

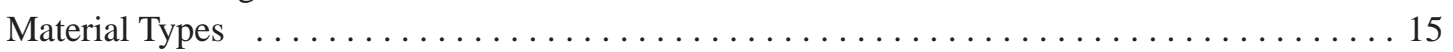

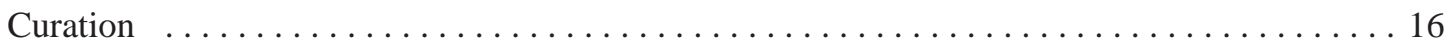

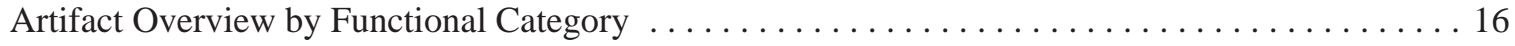

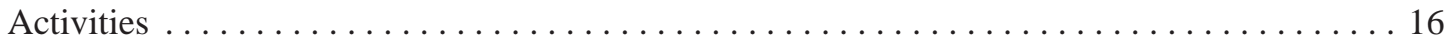

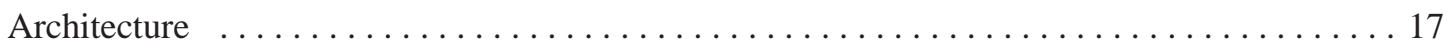

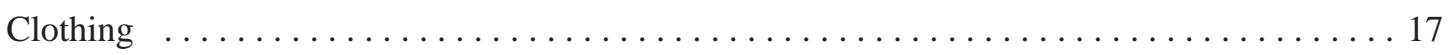

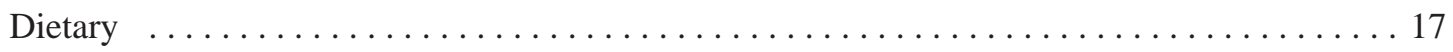

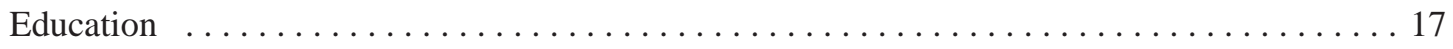

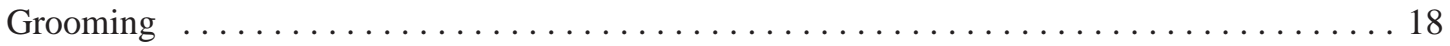

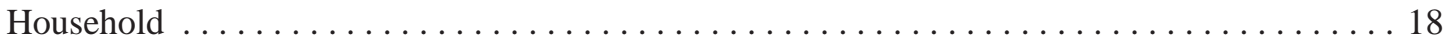

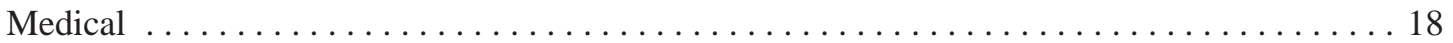

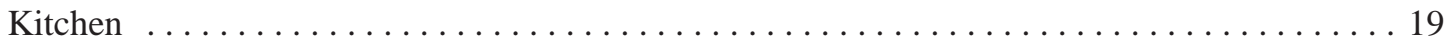

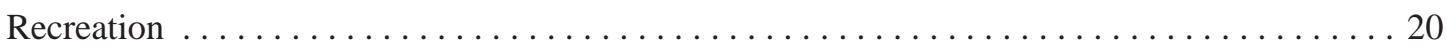

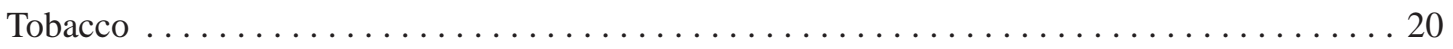

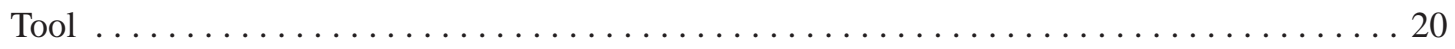

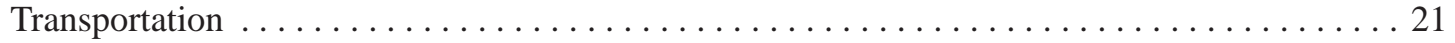

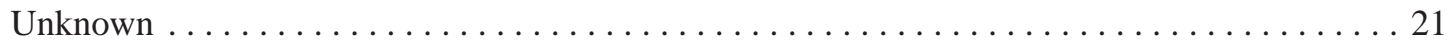

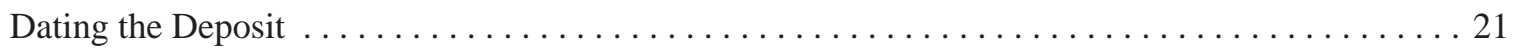

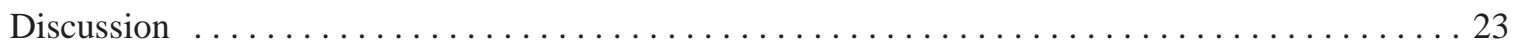

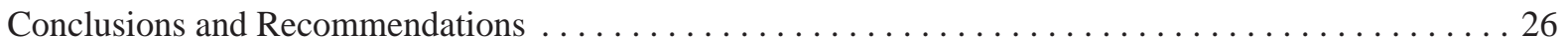

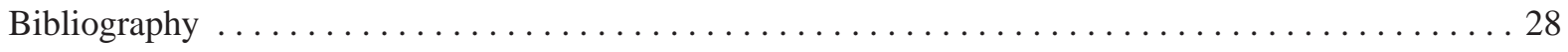





\section{List of Figures}

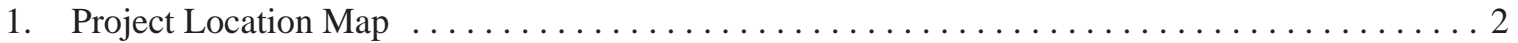

2. Plat map of S. M. Swenson 1871 Survey of the Prior Holder's League $\ldots \ldots \ldots \ldots \ldots \ldots \ldots$

3. Portion of 1926 State Highway Department Map for Williamson County showing the Hutto-Round Rock crossing Lot No. 5 and standing structures $\ldots \ldots \ldots \ldots \ldots \ldots \ldots$

5. Close up of well wall illustrating dry stack construction technique . . . . . . . . . . . . 14

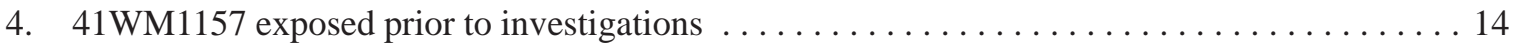

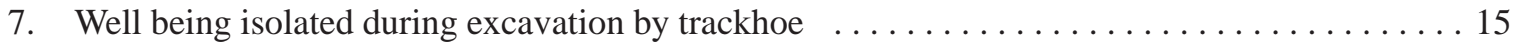

6. Original surface of well fill (following removal of upper portions of well) $\ldots \ldots \ldots \ldots \ldots 15$

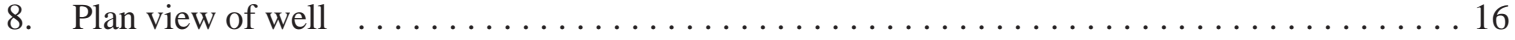

9. Bisection of well to bottom; note depth of trash deposit and water emerging at bottom . . . . 17

10. Activities Artifacts Recovered from the Enstrand Well: (A) Hi-Lex Bleach Bottle

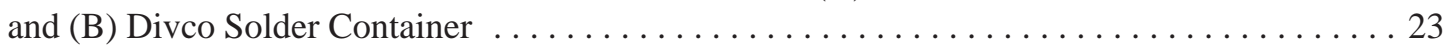

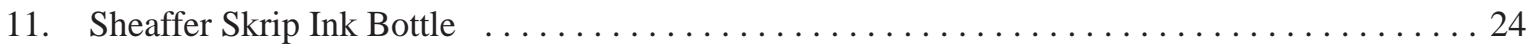

12. Various Grooming Related Artifacts Recovered From the Engstrand Well . . . . . . . . . 24

14. Various Medical Artifacts Recovered from the Engstrand Well: (A) Thatcher Manufacturing Bottle, (B) Philips Milk of Magnesia, (C) Brockway Glass Bottle (D) Owens-Illinois

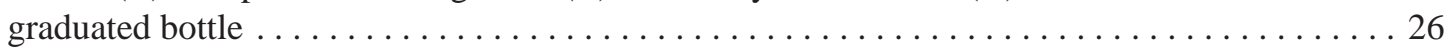

13. Various Household Artifacts Recovered From The Engstrand Well: (A-C) Flower Pot Sherds, (D,F) Light Bulb Bases, (E) Light Bulb Glass $\ldots \ldots \ldots \ldots \ldots \ldots \ldots \ldots \ldots \ldots$

16. Kitchen Artifacts Recovered From the Engstrand Well: (A) Ketchup Bottle, (B) Mustard Jar, (C) Possible Flavoring Bottle, (D) Hires Flavoring Bottle,

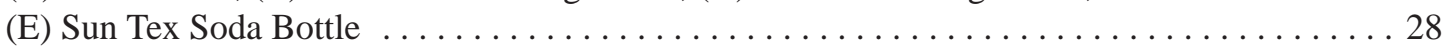

17. Kitchen Artifacts Recovered From the Engstrand Well: (A) Folgers Coffee Can,

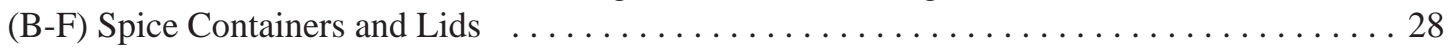

15. Kitchen Artifacts Recovered From Engstrand Well: (A-C) Canning Jars,

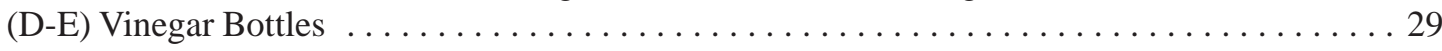

19. Kitchen Artifacts Recovered From Engstrand Well: Stoneware container with screw top lid . . 30

18. Kitchen Artifacts Recovered From Engstrand Well: (A) Fork, (B) Rectangular Ceramic Container, (C) Homer Laughlin Ovenserve Plate Fragment, (D) Spoon . . . . . . . . . 31 
20. Minnie Mouse Figure Recovered from the Engstrand Well. $\ldots \ldots \ldots \ldots \ldots \ldots \ldots \ldots \ldots$

21. Photo of Metal Milk Container Collected From Bottom of the Engstrand Well. . . . . . . . . . 33

22. Transportation Related Items Recovered From Engstrand Well: (A,B) Sparkplugs, (C) Gulf Pride Motor Oil. . . . . . . . . . . . . . . . . . . . . . . . . . . 33

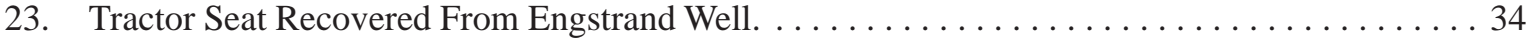

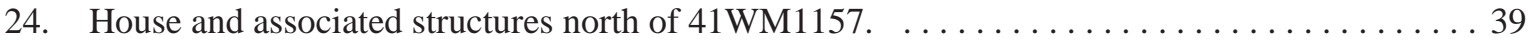




\section{List of Tables}

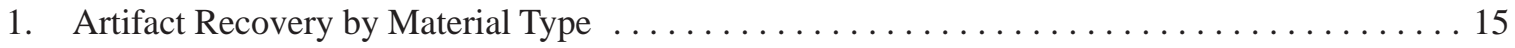

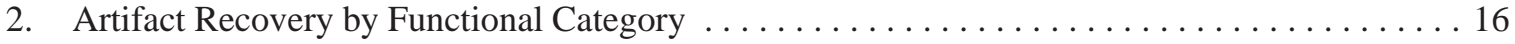

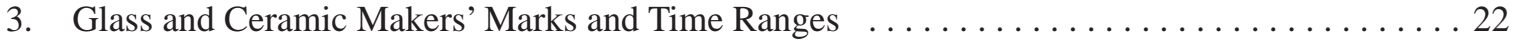

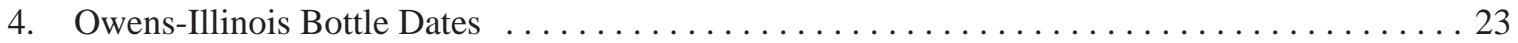





\section{List of Appendices}

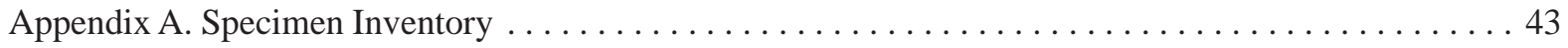

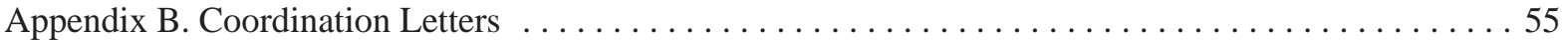





\begin{abstract}
Under TAC Permit 4347 Hicks \& Company undertook archival research and National Register eligibility archeological testing of a historic limestone well (Site 41WM1157) in the US 79 right-of-way in Williamson County, Texas under Texas Antiquities Permit Number 4347. The project was sponsored by the Texas Department of Transportation (TxDOT), for regulatory and management purposes under Section 106 of the National Historic Preservation Act (NHPA) and the Antiquities Code of Texas (13 TAC 26). Archival research was conducted in order to establish the history of ownership and land use for the property. Research revealed that the well was likely built during the 1870s by Carl Engstrand, a Swedish immigrant closely affiliated with the Palm Valley community. Testing involved mechanical excavation around the well to a depth of 2.74 meters ( $9 \mathrm{ft}$.) below ground surface in order to expose it and document its construction technique. Then the well was truncated and archeologists excavated the fill by hand to a depth of 3.84 meters ( $12.5 \mathrm{ft}$ ) below ground surface, screening and saving all artifacts. The remaining two meters $(6 \mathrm{ft})$, unreachable by hand investigations due to the constricting interior of the well, were excavated mechanically. The artifacts from the well represent unstratified mid-twentieth century farm household debris. Neither the well nor the artifacts within the well are considered eligible for the National Register of Historic Places or for listing as a State Archeological Landmark (SAL). A representative sample of the diagnostic artifacts and all project related records and photographs will be curated at the Texas Archeological Research Laboratory (TARL).
\end{abstract}





\section{Acknowledgements}

This project could not have been completed without the assistance of a number of individuals and organizations. First and foremost, the Texas Department of Transportation was instrumental in facilitating a speedy deployment into the field and providing concise and detailed guidance on findings made during the course of excavations at the site. A special "Thank You" is extended to Grace Telander, a long-time Round Rock resident whose direct recollections of the Palm Valley Community attributed greatly to our understanding of the well and it's social context. We would also like to thank Billy Benningfield of the Texas Department of Transportation for his added personal insight. Hicks \& Company historian Jan Root diligently pored over historic records to present the archeologists with an accurate image of who built the well and their place in the local history. Finally, Hicks \& Company archeologists James Karbula, Rachel Feit and Brad Jones should be applauded for braving the bracing cold and wind to explore the site and provide valuable insight into its contents and composition. 



\section{Chapter 1}

\section{Introduction and Management Summary}

In December 2006, Hicks \& Company undertook National Register eligibility testing and archival research at the site of a limestone well (41WM1157) located in the US 79 right-of-way in Palm Valley, Williamson County, Texas. The Texas Department of Transportation (TxDOT) was in the process of expanding the US 79 right-of-way at that location (from FM 1460 to CR 195), improving the facility to a four lane divided roadway with left and right turn lanes provided at some areas. Approximately 80 feet of new right-of-way was being acquired from the north side of the road only. The project was sponsored by TxDOT, for regulatory and management purposes under Section 106 of the National Historic Preservation Act (NHPA) and the Antiquities Code of Texas. All work complied with the guidelines set out under 36 CFR 800 and the Rules of Practice and Procedure for implementing the Texas Antiquities Code under 13 TAC 26. Site 41WM1157, the Engstrand Well, was unexpectedly found by construction crews in December of 2006 on the north side of the TxDOT right-of-way during the widening of the road. The property on which the well was located had been acquired by TxDOT from Marvin Cressman, who has owned the adjacent acreage since 1996. The property is located in the Palm Valley area of Williamson County east of Round Rock, an area that was originally settled by Swedes in the mid to late nineteenth century. It is just east of the Palm Valley Lutheran Church historic district. Formerly, the land was cultivated and used as pasturage. It is currently under construction as part of the US 79 expansion project.

Hicks \& Company was contracted to conduct emergency archeological investigations of the well to determine the site eligibility for listing on the National Register of Historic Places (NRHP) under
36 CFR 60.4 or as a State Archeological Landmark (SAL). Because the US 79 expansion project involves TxDOT owned right-of-way, the project falls under the purview of both National Historic Preservation Act and the Texas Antiquities Code (TAC). Investigations were coordinated with TxDOT and the Texas Historical Commisiion (THC) and occurred under Texas Antiquities Permit 4347. Work consisted of archeological and archival research investigations of a hand-dug well located within the current expanded right-of-way for US 79 (Figure 1). The well is likely associated with a standing historic-age structure located approximately 60 meters to the north. The structure is now unoccupied. Research revealed both the well and the house were likely built by the Engstrand family, Swedish immigrants who purchased the property in 1871 . Descendants of the Engstrand family owned the property until the last quarter of the twentieth century. The property was occupied occasionally by members of the Engstrand family, who farmed and raised livestock there, but otherwise tenants lived on it.

Archeological investigations consisted of mechanical and hand excavations of the limestone lined, hand-dug well to its base, to recover artifacts that could contribute to the site's eligibility for listing on the National Register of Historic Places (NRHP). The mechanical investigations revealed that the well was made entirely of rough-hewn tabular limestone blocks and extended more than 20 feet below the surface. Investigations documented approximately three meters of refuse accumulation within the well, all of it from the mid-twentieth century. The majority of the material consisted of rusted cans, metal and glass bottle items. Only a small amount of personal, decorative, or tableware related items was recorded. Investigators noted no 
2 Archeological Testing of the Engstrand Well 41WM1157, in Williamson County, Texas

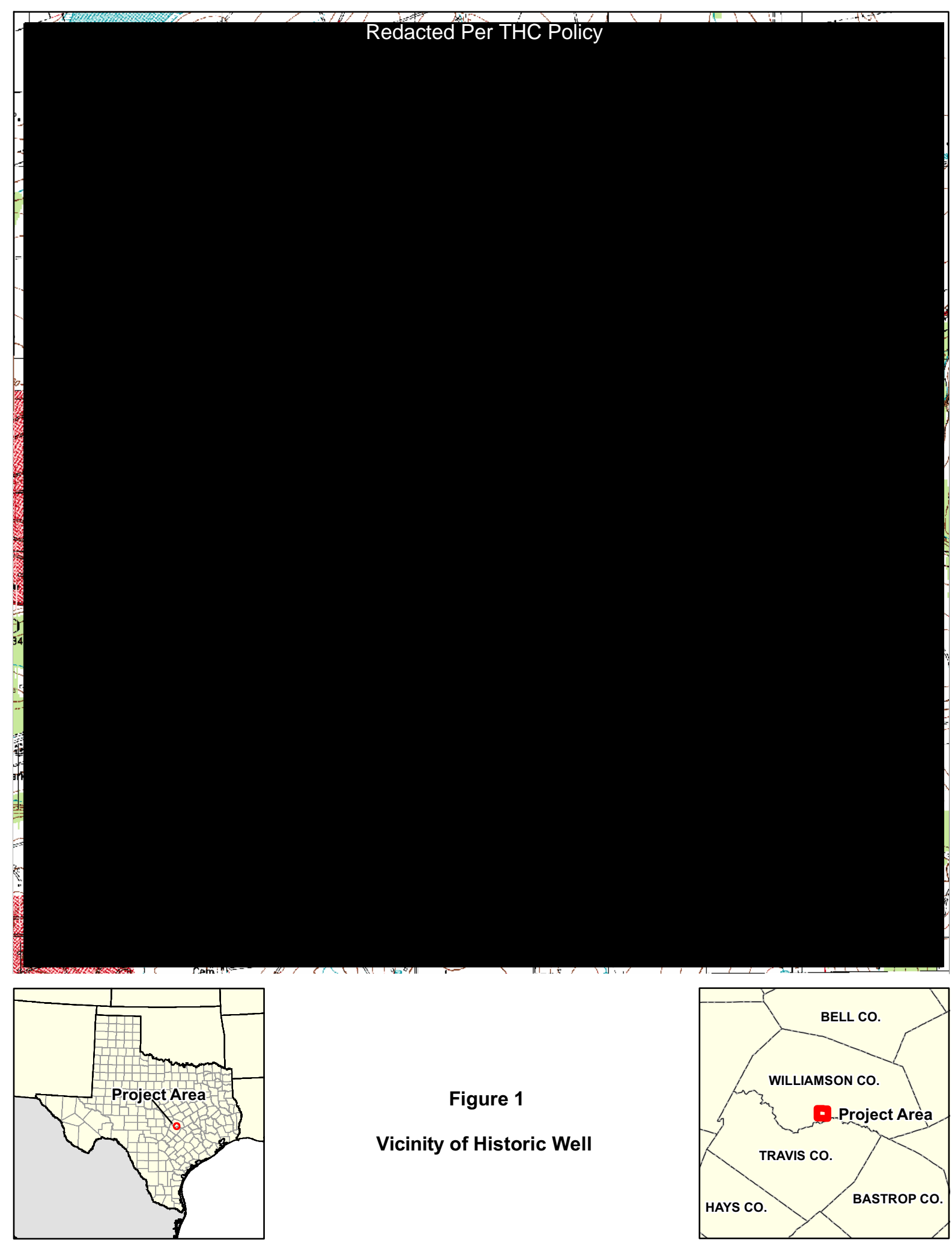

Figure 1. Project Location Map. 
internal stratification in the fill that could be linked to individual disposal episodes through time. Indeed, the refuse primarily dated to a narrow time frame roughly 1940-1950. No nineteenth or early period artifacts were found that could contribute to the well's NRHP- eligibility under Criterion D. Archival research and evaluation of the well itself did not provide any data that would allow the well alone to be listed on the National Register under Criteria A-C.

The field investigations were conducted in December of 2006. James Karbula functioned as the Principal Investigator. Rachel Feit served as Project Archeologist and Bradford Jones functioned as the senior field technician and laboratory supervisor. Bitter cold and a stiff north wind not withstanding, no logistical difficulties were encountered during the course of fieldwork. Suzanne Smith assisted in the laboratory analysis and curation and Hans-Jurgen Dietrich provided graphics support. Historical research in support of the project was conducted by Rachel Feit, Bradford Jones and Jan Root. The results of field investigations were coordinated through an interim report dated December 21, 2006 and submitted to TxDOT-ENV. The report recommended that the well and its contents are not eligible for National Register Listing or as a State Archeological Landmark. TxDOT and the Texas State Historic Preservation Officer (SHPO) concurred with that recommendation on January 18, 2007. Detailed inventory and analysis of the more than 1,100 artifacts from the well took place in April and May 2007. Through an agreement made between Hicks \& Company, TxDOT-ENV and SHPO (letter dated April 12, 2007, see Appendix B), only a sample of the artifacts collected during the project will be curated. This is due to the non-diagnostic, redundant, and/or fragmentary nature of many of the artifacts. Final report writing occurred during May 2007. A selected sample of analyzed artifacts and all project documents and photographs will be curated at the Texas Archeological Research Laboratory.

The remainder of this report includes sections on Historical Background and Previous Archeological Investigations, Environmental Background, Results of Investigation, Artifact Analysis, and Conclusions and Recommendations. 



\section{Chapter 2}

\section{Historical Background and Previous Archeological Investigations}

Historical research was conducted by Hicks \& Company historians and archeologists utilizing resources in the Williamson County Clerk's Office, the online United States Census data, archives at the Austin History Center, and secondary sources available through public libraries. Oral histories were also collected from Grace Telander a longtime Round Rock resident, Billy Benningfield a TxDOT district employee and longtime Round Rock resident, and Monica DeVries, the chief administrator of the Palm Valley Church.

The dry stack constructed well-41WM1157uncovered during the expansion of US 79 in Palm Valley is located on agricultural property that was owned by members of the Engstrand family for over 100 years. Carl Engstrand and his wife Johanna were both Swedish immigrants, and part of the close-knit network of Swedes in Travis and Williamson Counties. An abandoned house was noted outside the right-of-way, approximately 60 meters to the north, and is likely related to the well, as both are part of the Engstrand property. The house was outside the TxDOT right-of-way and would not be impacted by the proposed project. Hence, it was not part of the scope of this project to assess it with respect to National Register eligibility. From the right-of-way, the house appeared to be over 50 years in age, constructed during the latter part of the nineteenth century.

\section{SWEDES IN TEXAS}

Between 1848 and the end of the nineteenth century, several thousand Swedish families came to Texas at the promise of cheap land and greater economic opportunities. The man responsible for bringing Swedes to Texas was Swante Magnus Swenson, who arrived penniless in Texas in 1839 (Moore 1996:176). Working first as a delivery boy for a mercantile business in Columbia, Texas, Swenson soon became the overseer at a nearby plantation. When the owner of the plantation died of tuberculosis, Swenson married the widow and became a wealthy man. Over the ensuing years he increased this wealth significantly through shrewd land purchases, banking interests, ranching, railroads, and mercantile ventures around the country (Moore 1996)

With the help of his uncle Swante Palm, who arrived in Texas in 1844, in 1847 Swenson returned to Sweden and began enlisting other immigrants to join him in Texas. The first group of immigrants came in 1848 and included Anna Palm. After spending time working on Swenson's plantation in Richmond, in 1853 they settled on land around Brushy Creek in Williamson County that Swenson owned. Another large group of immigrants arrived after the Civil War, in 1867. Though Swante Swenson left Texas in 1871 to live in New York, he continued to promote Swedish immigration through Swante Palm who resided in Austin. Swedish communities in Travis and Williamson counties sprang up in New Sweden near Manor, near Hutto and around what is now Decker Lake (Anonymous 2007). Almost all of these communities were oriented toward farming and agriculture. Mrs. Emil Peterson Lundstedt described her childhood in the early twentieth century on a farm outside of Round Rock as one of perfect contentment. Her father raised primarily cattle, sheep and chickens, but also farmed cotton. Typically the Lundstedt family would drive in their surrey into Round Rock to sell their milk, eggs, and cream, which they 
generated at a surplus on the farm. Farm help was usually provided by one or two recent immigrants from Sweden (Lundstedt 1978).

Most of the new immigrants who came were too poor even to pay their own passage. Following a system Swenson established for the first wave of immigrants, typically, a landowning Swede would pay for passage of an immigrant in exchange for a year's labor. It is estimated that $90 \%$ of Swedes in Texas made the journey in this manner. After the year was up, immigrants then rented farmland or worked for another family until they had saved enough to purchase their own property. Often Swedes would collectively purchase large agricultural tracts that they subdivided and sold off to other Swedes. In this manner they formed close communities that afforded inexpensive labor to landowners, while offering economic and social support to recent immigrants (Anonymous 2007).

Mutual aid societies also helped Swedes in times of crises. The Swedish Horse Society, for instance, was informally founded in the 1870 s by a group of farmers to insure reimbursement if a horse was stolen or lost, and prosecute horse thieves. By 1911 the Goetha Mutual First Insurance Association was offering property insurance to Swedes against theft, fire and other property damage. These support networks and others oriented around the Lutheran churches allowed Swedes to prosper during the late nineteenth century (Swedish Pioneer Historical Quarterly 1965). The Austin American Statesman noted in 1915 that Swedes and Germans owned more farms in Travis and Williamson County than any other ethnic group (Texas Writers Project 193[u]).

Each midsummer Swedes around the Round Rock area would gather for the "Old Settlers" picnic. While each winter they would gather at the Palm Valley church for a special Christmas tree program (Lundstedt 1978). The 1900 Austin American Statesman described the annual midsummer festival. The festival featured a brass band, a 50-foot maypole, Japanese lanterns strung up in the trees, and tables draped in Swedish colors. At the picnic, the guests made speeches, sung the Swedish national hymn and partook in a huge banquet that lasted until two o'clock in the morning (Texas Writers Project 193[u]). Through mutual aid organizations, churches, and organized gatherings the Swedish communities of central Texas remained cohesive and their traditions largely unchanging well into the twentieth century.

\section{SPECIFIC HISTORY OF SITE 41WM1157}

The limestone well is part of a property that was first improved by Carl Engstrand and his wife Johanna. The property was platted in 1871 as Lot No. 5 of the Swenson Survey (Figure 2; WCDR 13/119). Within the larger Swenson Survey there were 17 lots, of which Lot No. 5, at 80 acres, was the largest tract. The Swenson Survey was conducted in what was originally known as the Prior A. Holder League on Brushy Creek. This land had apparently been acquired sometime earlier by Swante Magnus Swenson.

By the time that Swenson platted the land in 1871, the Palm Valley area had already become a growing population center for Swedish immigrants. The earliest Swedish settlers in the Palm Valley area were Anna Palm and her six sons who had moved to the region from Swenson's plantation in Richmond, Fort Bend County, near Houston (Behrens and Widmer 1995:1). In the years between the Palm's arrival in 1853 and the Swenson Survey in 1871, the Swedish community in Palm Valley grew with the addition of new families and the establishment of organized religious services for the community beginning in the 1860s. When Anna Palm's youngest son died in 1863, he was buried in a property just west of Lot No. 5, a site that would become the site of the Palm Valley Lutheran Cemetery, following Swenson's donation of the land (Behrens and Widmer 1995:3). In 1871 Swenson donated just over 21 acres for the cemetery and the construction of a church and school to the Swedish Lutheran Church Association, among the first trustees of which was a Carl August Engstrand, a Swedish immigrant (Behrens and Widmer 1995:3; WCDR15/233).

Carl August Engstrand and his wife Johanna were both born in Sweden, he in 1846 and she in 1847. They immigrated to the United States in 1867 during a time when Swenson was actively recruiting Swedes to Texas. They became naturalized citizens in 1877 (U.S Census 1930). The couple first appeared in the 1870 census for Travis County, at which time Carl's occupation was listed as a farmer 


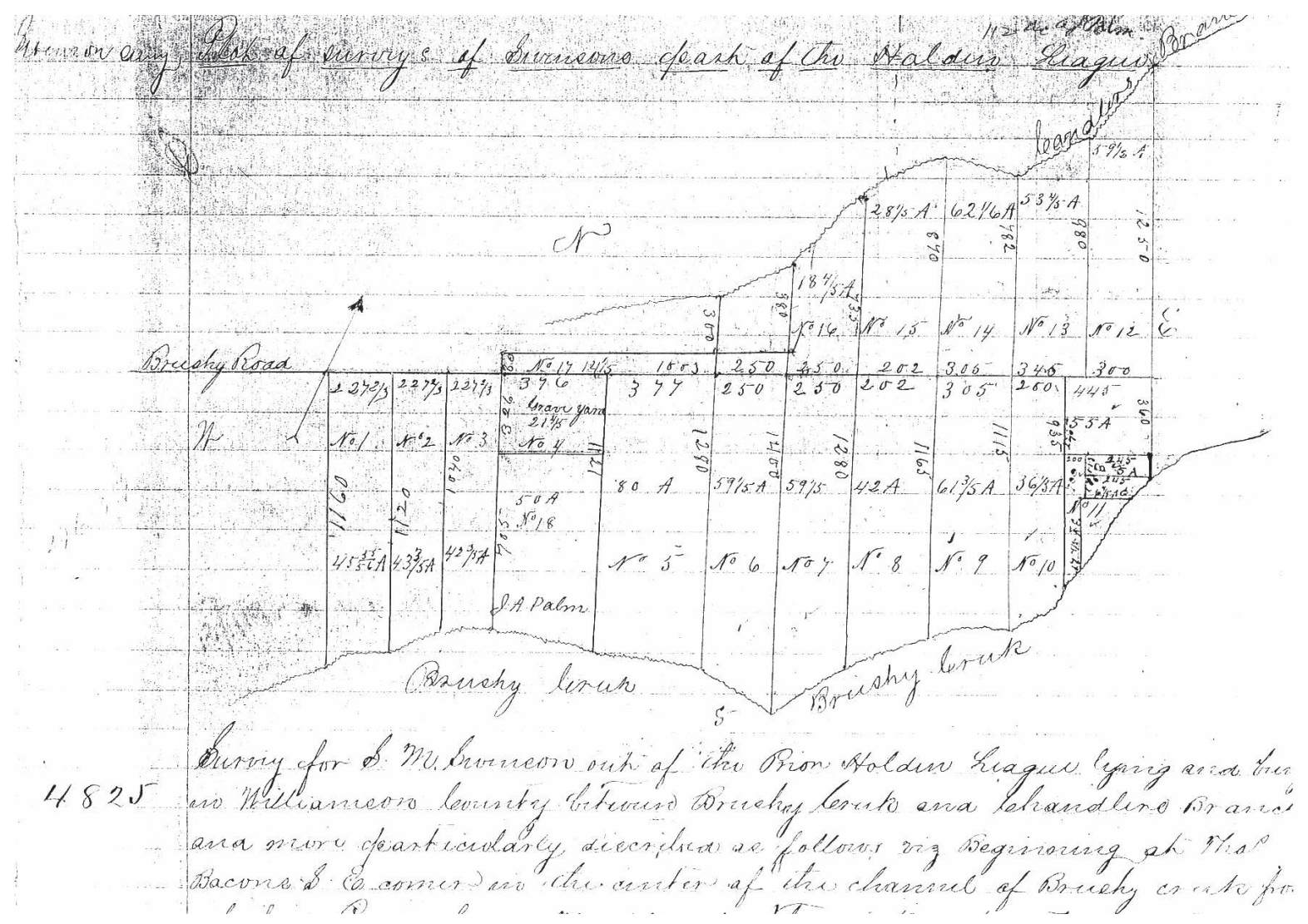

Figure 2. Plat map of S. M. Swenson 1871 Survey of the Prior Holder's League.

and she a housekeeper. At that time they would have completed their year's indentured servitude, but were probably working on another landowner's farm to save enough money to purchase their own property. In the 1870 census they are recorded as having two children: a boy Johannes, age 4, and a girl Isabella, age 1. On June 1, 1871, they purchased Lot No. 5 along with "C" of Lot 11 from Swante Swenson (WCDR 15/207) through a series of promissory notes. By April of 1878, Engstrand had paid off the vendor's lien for all these properties he had purchased from Swenson (WCDR 19/589). It is likely that a house and the well were probably built on Lot 5 sometime during the 1870 s or early 1880 s.

During the 1880s Engstrand continued to acquire several other properties from Swenson within the Prior A. Holder League. By 1883, these included Blocks B and C of Lot 11, and in 1878 Lot 18 which is the lot adjacent to Lot No. 5 on the west side (Figure 2). At the time that Lot 18 was purchased it was the residence of Palm Valley's earliest settler Anna Palm, in recognition of which
Swenson stipulated that she "shall have the right and privilege to occupy said premises and to use the same for her purposes and beholds and as long as she lives if she so desires" (WCDR 49/90). Thus by the end of the 1880s, Carl A. Engstrand, a founding trustee of Palm Valley's Swedish Lutheran Church Association, had become a significant property holder and Palm Valley community member.

Because they are not recorded in the 1880 Census, the exact location of the Engstrand's residence is unclear. As church trustee and an important family within the Palm Valley community, it is likely they lived on Lot 5 for some time. However, in 1889 they purchased land in the City of Round Rock from A. J. Nelson and began constructing a home in the same year (WCDR 51/ 240). According to Grace Telander, a longtime Round Rock resident, that house was located on Main Street (Grace Telander, personal communication 2006). In the 1900 Census, the Engstrands, including Carl (his name is recorded incorrectly as Charles), Johanna and two daughters 
Hilda and Sarah, were living in the city of Round Rock. At this time Carl's profession was listed as a landlord. At the time of the 1910 Census, however, Carl and Johanna Engstrand were residing outside of Round Rock in Justice Precinct 7, likely on their Palm Valley property. At this time Carl was no longer listed as a landlord, but rather was employed as a clerk in a hardware store. One of their neighbors, Richard D. Barnes, is listed in the 1910 Census as a Freight Agent for the railroad, a strong indication that Justice Precinct 7 included the Palm Valley freight depot stop. This stop was located opposite the Palm Valley Church on the International-Great Northern Railroad (Leffler 1996:26).

More interesting, the neighbors of the Engstrands are the Voigt family, into whom the Engstrand's daughter Isabelle, now 40 years old, had married. Isabelle's husband was Otto A. Voigt, age 38, who worked as a plumber (Grace Telander, personal communication 2006). The Voigts lived with their two sons, Alexius and Arno ages 9 and 7, and three daughters Lorraine, Xenia, and Kathleen ages 11, 5, and 2. Though speculative, the Engstrands move out of the city during this period may well have been to assist their daughter care for her five children.

By the time of the 1920 census, Carl and Johanna Engstrand were again residing in their Round Rock home. In the 1920s several changes began to occur with the Engstrand property in Palm Valley. On August 4, 1925, Carl sold a portion of his Palm Valley properties including a part of Lot No. 5 to the Lone Star State Power Company, Inc. as an easement for an electric transmission and distributing line. Worth noting, in this deed he states that the lands are "not a homestead I owning my home in the town of Round Rock" (WCDR 224/ 376). By 1926 the State Highway Department map for Williamson County shows the completion of the Hutto-Round Rock Road (now US 79), which effectively divides Lot No. 5 just south of the location of the well (41WM1157) (Figure 3). On this map, two houses are shown about equidistant from the well location (the well is not depicted). One is the house currently standing approximately 60 meters to the north of the well. The second house no longer exists but was located to the east. It is likely this well would have served one or both of these houses.

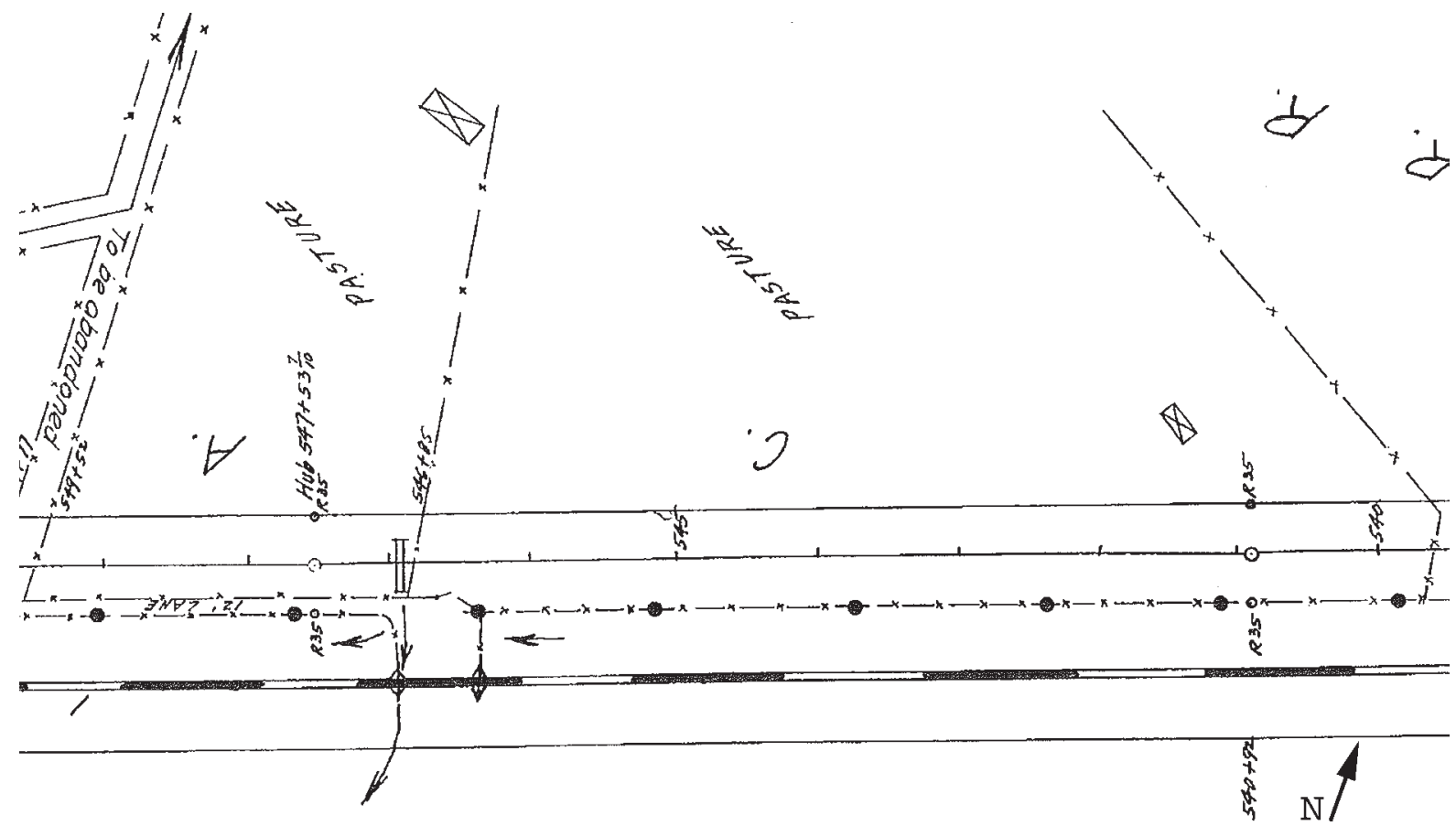

Figure 3. Portion of 1926 State Highway Department Map for Williamson County showing the Hutto-Round Rock crossing Lot No. 5 and standing structures. 
The Engstrands continued to own Lot No. 5 and the rest of their Palm Valley properties until their deaths in 1933. These early members of the Swedish community in Palm Valley and Round Rock were laid to rest in two burial plots in the cemetery of the Palm Valley Swedish Lutheran Church.

Upon the death of Carl and Johanna Engstrand in 1933, their Palm Valley properties, including Lot No. 5, remained within the Engstrand family line through transfer to their granddaughter Lorraine Voigt who served as the administrator of their estate. In this same year Lorraine Voigt sold Lots No. 5 and 18 to her father, Otto A. Voigt. The Voigt family continued to own properties in Palm Valley, and remained active members of the community and in the church. Billy Benningfield recalls that Engstrand's granddaughter Xenia Voigt, his first grade teacher, lived on Lot No. 5 in the house still standing (Billy Benningfield, personal communication 2006). This would have been during the late 1960s or early 1970s. In December of 1984, Carl Engstrand's granddaughters also established the Xenia Voigt and Kathleen Payne Endowments at the church (Behrens and Widmer 1995: 12). In 1990 Xenia Voigt and Kathleen Payne established the Voigt and Payne Gift Account for the church. In this same year Kathleen Payne passed away, but her sister Xenia, granddaughter of Carl and Johanna Engstrand, lived until 1996. The property is currently owned by Marvin Cressman, a retired surgeon and longtime Round Rock resident
(Deed 1755-329; Grace Telander, personal communication 2006).

\section{PREVIOUS ARCHEOLOGICAL RESEARCH}

Previous environmental work around Site 41WM1157 includes an archeological impact evaluation performed by Prewitt \& Associates in 2002 that took place along US 79 in the project area. That survey did not identify Site 41WM1157 and the report was coordinated on September 11, 2002. In addition, a number of surveys have taken place around the project area prior to residential and infrastructural development, including one conducted by Hicks \& Company in 1999 (Griffith and Feit 1999) prior to installation of a wastewater line along Chandler Creek. Nearby sites include a number of historic sites related to the Palm Valley Community (Sites 41WM675, 41WM677, 41WM678, 41WM683, and 41WM739-743) and six small prehistoric lithic scatters (41WM674, 41WM676, 41WM679, 41WM681, 41WM682, 41WM952). The Palm Valley Lutheran Church property, located to the west of the project area, is on the National Register of Historic Places. One historic archeological site, located approximately $1 / 2$ mile south of the current project is Kenney's Fort (41WM465), which was established as a fortified frontier home in 1838 and is on the National Register of Historic Places. 



\section{Chapter 3}

\section{Environmental Background}

The project area is located on a broad, relatively flat ancient flood terrace on the north side of Brushy Creek. Most of the area is former agricultural land and has therefore been largely cleared of trees and any natural topographic relief.

The project area is in the ecological region known as the Blackland Prairie. The region is grassland characterized by gentle topography and in its natural state is predominantly covered with native grasses including little bluestem (Schizachyrium scoparium), big bluestem (Andropogon gerardii), Indian grass (Sorghastrum nutans), and tall dropseed (Sporobolus asper) in the uplands and eastern grama grass (Tripsacum dactyloides) and switch grass (Panicum virgatum) in the lowlands (Gould 1975). The generally southeasterly trending river and stream drainages are home to elm, cottonwood, pecan, oak, and sugarberry trees. Today much of the region is agricultural land, with an emphasis of cotton, corn, milo and wheat. Blair (1950:101-102) notes the presence of an array of mammal species including deer, rabbit, coyote, bobcat, as well as many reptiles, amphibians, and snails.
In the immediate vicinity of the well, historic agricultural use has modified the natural vegetation. Currently the dominant vegetation around the project area consists of introduced grasses used for residential and commercial landscaping and hay. Nearby tree species observed include hackberry, live oak, and pecan.

The underlying geology consists of Holocene and Pleistocene terrace deposits composed of gravels and clays forming an alluvial fan along the Brushy Creek drainage basin. The surrounding underlying geology is Eagle Ford shale, formed during the Lower Cretaceous Period. The major soil is Krum Silty Clay (KsA), which is characterized by deep, dark grayish brown clay overlying clay substrata. Investigations documented approximately 40 centimeters of dark brown silty clay (10YR 2/1), over very loose gravelly loam $(7.5 \mathrm{YR} 3 / 3)$ to a depth of approximately four feet. This overlays a zone of aggrading caliche lightly mixed with reddish clay (7.5YR 5/6). The lowest soil zone consisted of pale sandy clay (10YR 6/6) mottled with eroded caliche. 



\section{Chapter 4}

\section{Results of Field Investigatons}

Testing of the well was conducted using a combination of mechanical excavation to expose the well and hand excavation of the well to collect and document artifacts. Testing proceeded in the following manner. First, Hicks \& Company archeologists mapped and recorded the well as it was exposed on the surface. This included mapping the well using a GPS, doing a line drawing and taking notes and photographs. Investigators placed a small amount of fill dirt from the surface in the well to protect the artifacts inside from damage during the mechanical excavation. Next, a trackhoe was used to dig around the well, exposing the well to a depth of approximately 2.74 meters ( 9 feet) below ground surface, just above the level of the fill in the well.

After the well had been exposed, it was photographed, then the trackhoe was used to remove the upper portions. Hicks \& Company archeologists then cleaned the surface of the well to re-expose it. The fill dirt placed in the well was removed and the previously exposed surface was cleaned and documented. Excavation then proceeded in 20-centimeter levels, excavated by hand with a trowel and shovel, with all excavated material screened through a $1 / 4$ " hardware mesh screen. Excavation continued in this manner through five levels (the last level was a 30-centimeter level) at which point the hand excavations had to be terminated due to a lack of space and the danger presented by excavation within such a narrow and small area. The elevation of each level was from an arbitrary datum established 2.44 meters ( 8 feet) below the original ground surface. This datum was later mapped with respect to the well, ground surface, and surrounding features using a TDS.

In order to investigate the well to its lowest depth, the trackhoe was used to bisect the well to depth. Depth was reached at approximately 20 feet (5.9 meters) below the well surface at the point that the water table was encountered. The bisected well was photographed and documented and a sample of fill material investigated for temporally diagnostic artifacts.

The results of the archeological testing documented a circular well constructed of rough-hewn tabular limestone that extended to a depth of 5.9 meters (20 feet) below the surface at the time of investigation (Figure 4). The construction style was dry-stack, though a small amount of mortar was noted in the upper layers of stone suggesting at least some mortaring to ensure the stability of the surface (Figure 5). Observed during the excavation of the well structure was the original limit of excavation of the well shaft visible as a darker soil surrounding the outside of the well. From the surface, investigators noted that the well contained historic period debris and soil fill starting at approximately 10 feet (3 meters) below surface (Figure 6). The construction of the well is fairly typical of the nineteenth century. A number of similar nineteenth century wells (Clark 2004; Feit and Clark 2002; Anthony 1996; Wright 1997) have been recorded in Austin and San Antonio.

After cleaning, drawing, measuring and photographing the well from the existing surface, a trackhoe was used to first reveal then truncate the well to the depth of the observed fill debris in the well (Figures $\mathbf{7}$ and 8). Once this was done, the trackhoe cleared an area around the well, to enable investigators to work at the trench's base, sloping the walls for safety in conformance with Occupational Safety and Health Administration OSHA regulations. Sloping at a 1:1 ratio of the northern edge of the trench was prevented by the presence of 
14 Archeological Testing of the Engstrand Well 41WM1157, in Williamson County, Texas

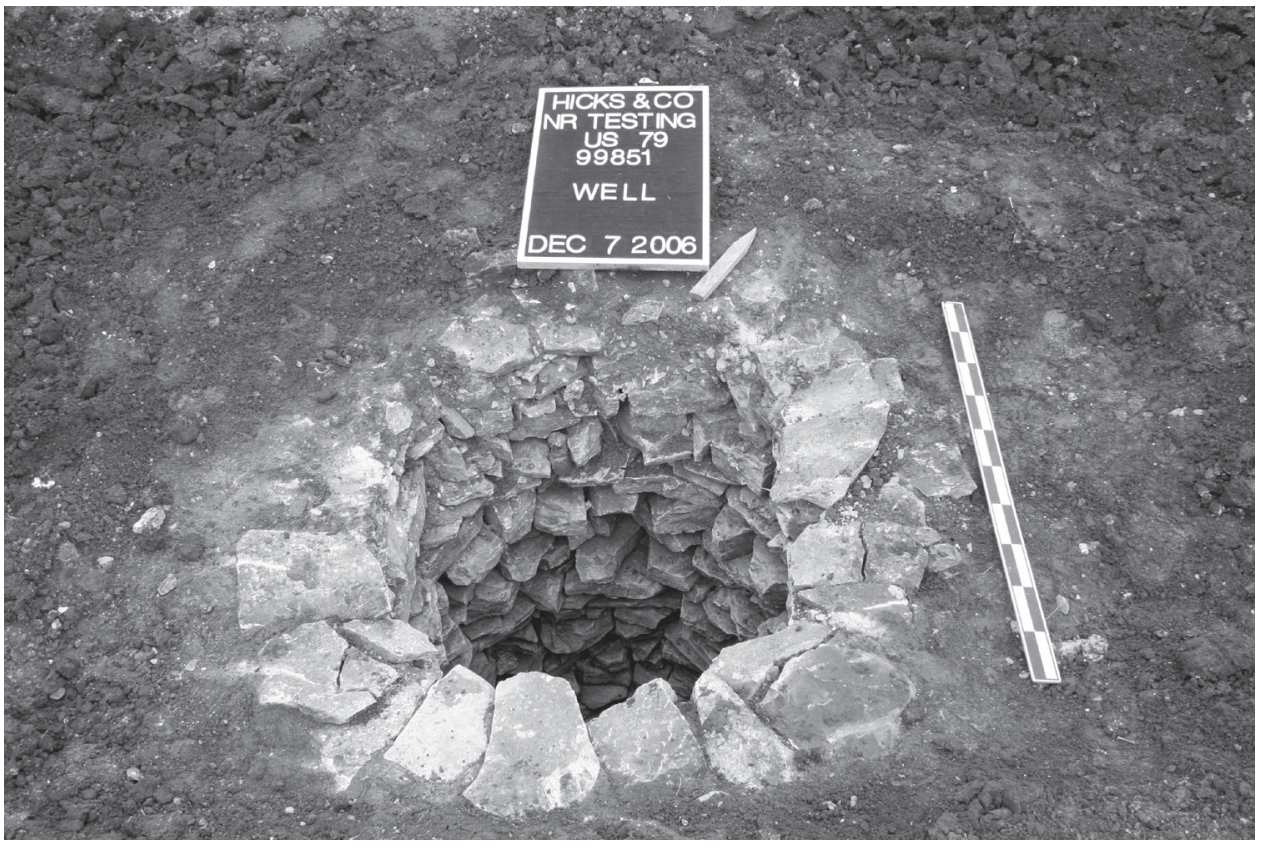

Figure 4. 41WM1157 exposed prior to investigations.

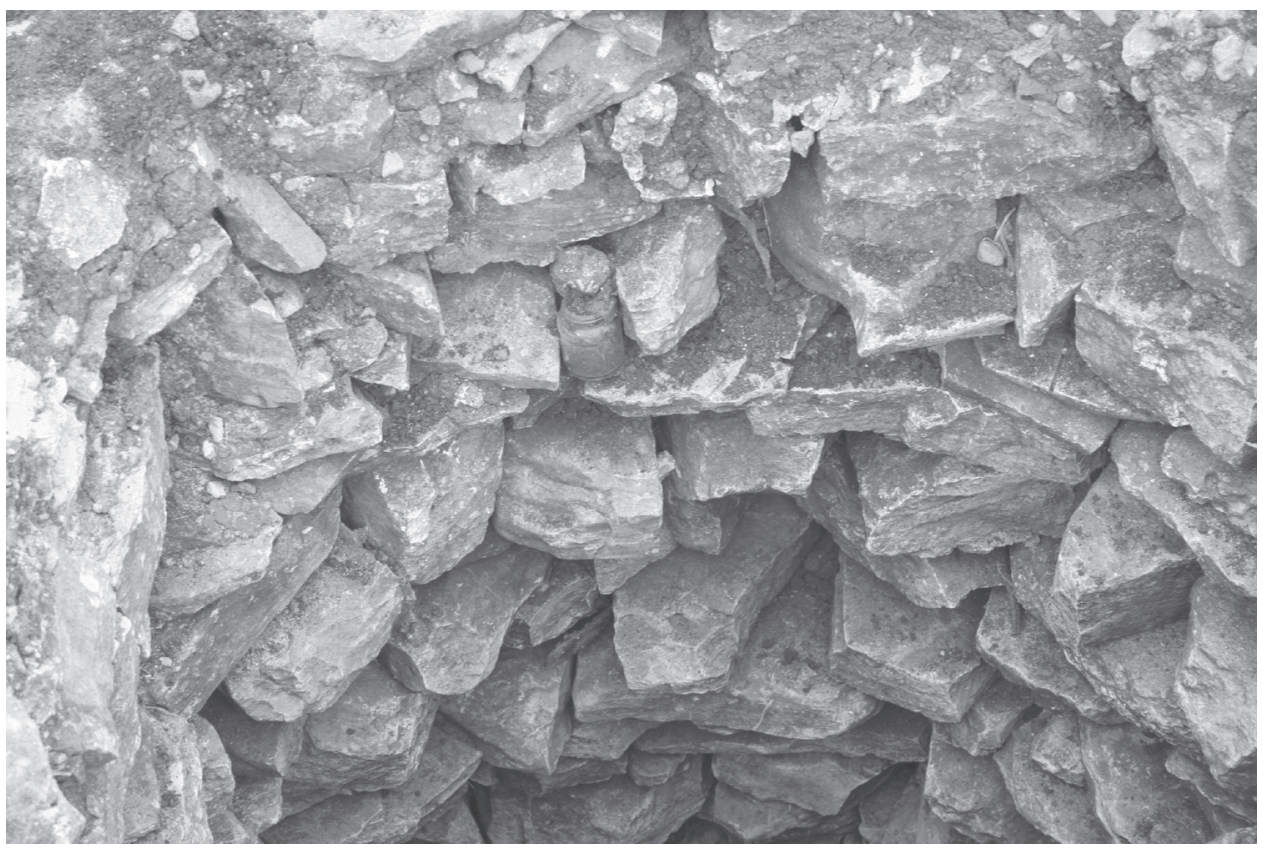

Figure 5. Close up of well wall illustrating dry stack construction technique. 


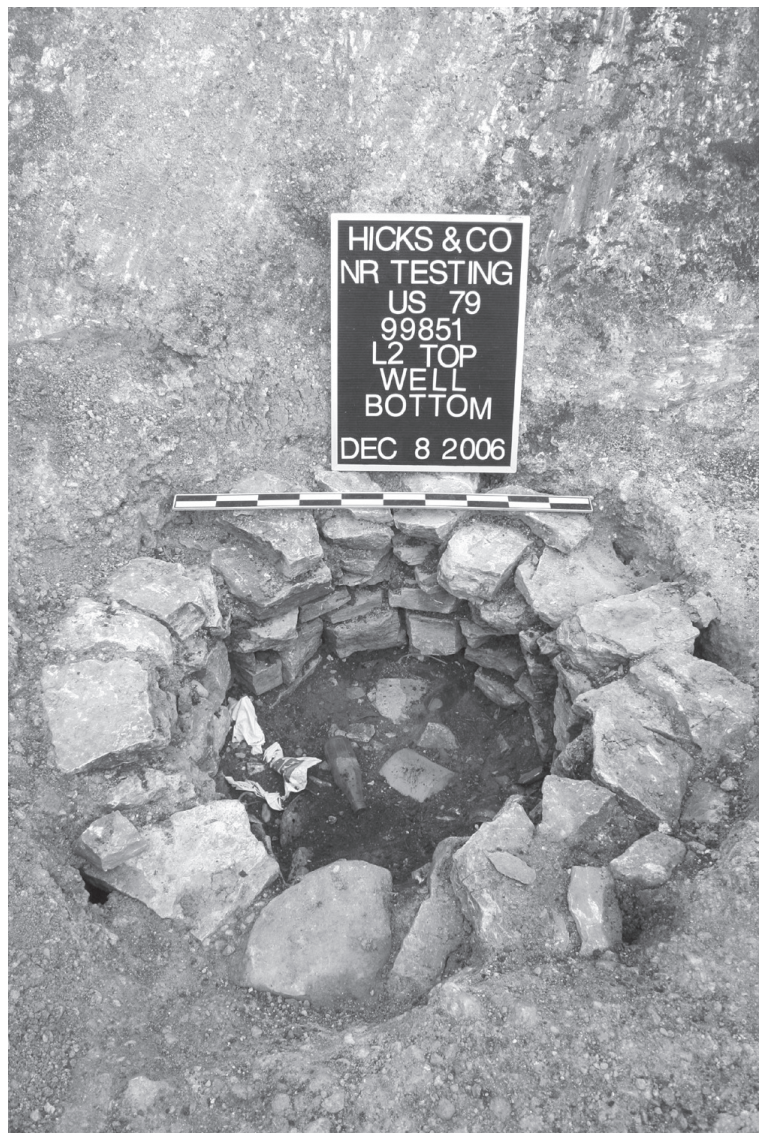

Figure 6. Original surface of well fill (following removal of upper portions of well).

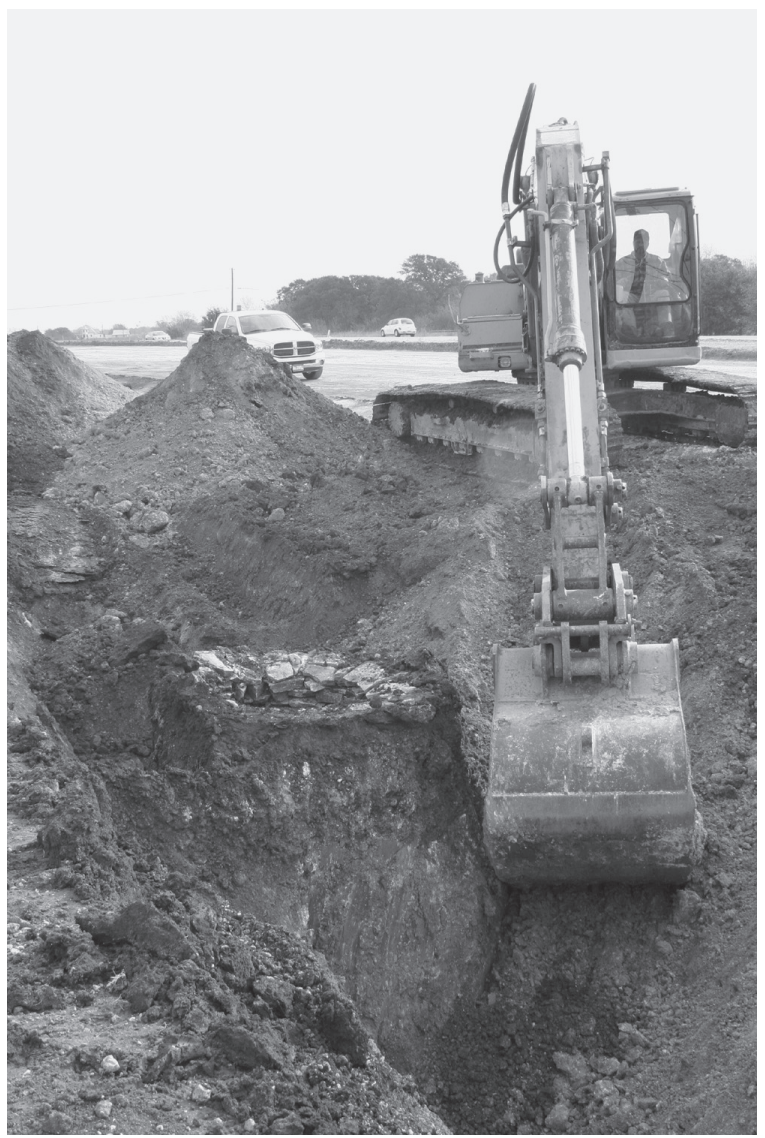

Figure 7. Well being isolated during excavation by trackhoe. 


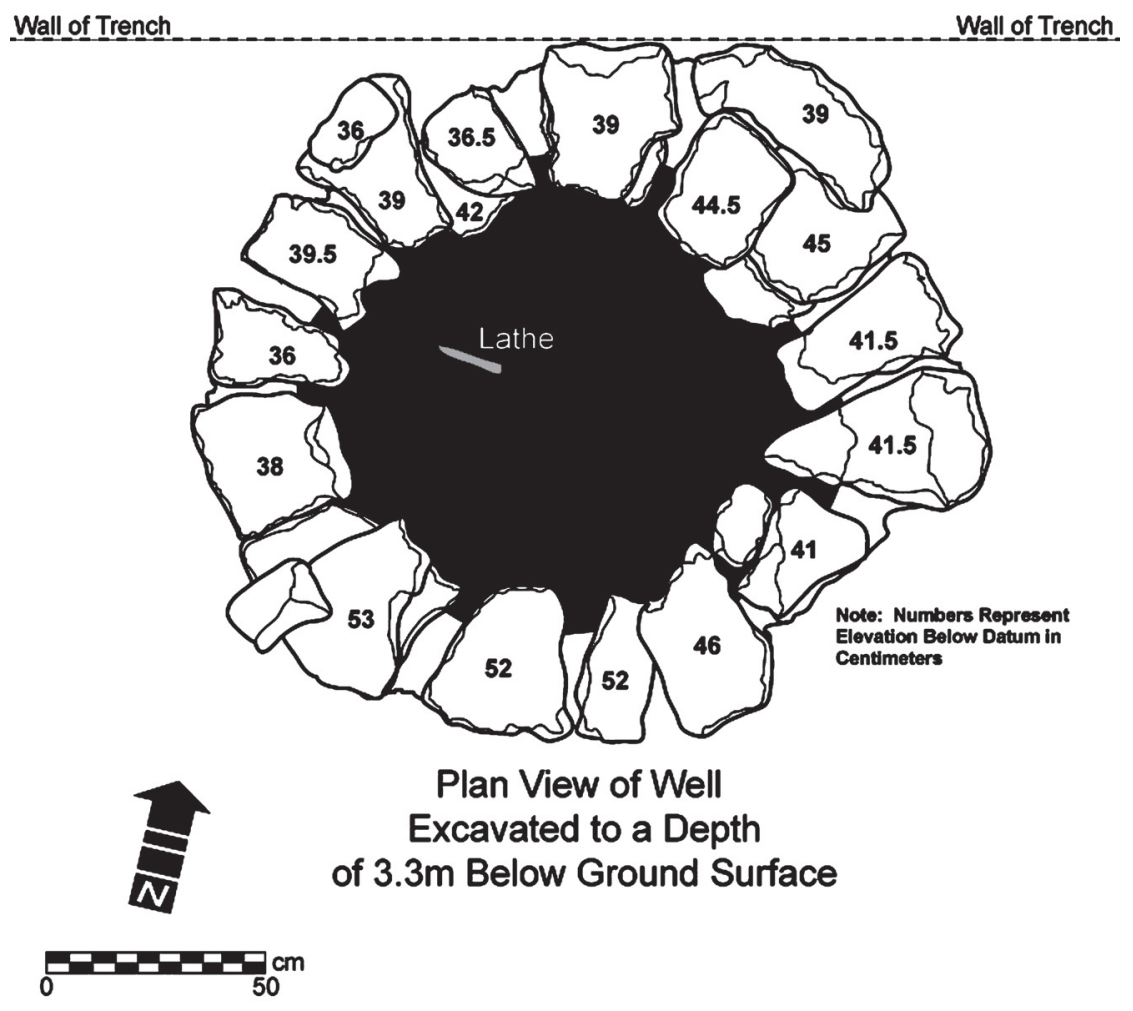

Figure 8. Plan view of well.

a fiber optic line less than 10 feet from the well; however, all other sides of the trench were sloped at a ratio of $1: 1$ or greater.

Investigators then proceeded to remove the soil and artifacts from within the well. Fill was removed in 20-centimeter levels, through four levels; the fifth level was a 30-centimeter level. Each handexcavated level was screened through $1 / 4$ "-inch wire mesh. The soil within the well consisted of moist, sticky brown, silty clay (10YR 3/2). After the last level, it became very difficult to continue hand excavations, not only due to the narrow confined space and depth of the well, but also due to the large amount of artifacts emerging from the well. Thus investigators employed the trackhoe to bisect the remainder of the well to document its total depth, which was 5.9 meters (20 feet) below the surface, with soil and artifacts extending all the way to its base (Figure 9).

The well fill was largely unstratified, and artifact age bore no correspondence to its vertical location within the soil column. Indeed, the well fill was remarkably uniform in terms of artifact com- position, density, and age range. This suggests that the well was filled in a relatively short period of time, perhaps with a pre-existing accumulation of debris. Further, the types of artifacts within the well represent an incomplete household assemblage. There were very few fragments of bone, ceramic, cutlery, furnishings, recreation and personal items. Indeed, the assemblage is more characteristic of materials in a shed than something that came directly from a household. For this reason, investigators speculate that the artifacts may have been allowed to accumulate in a barn or shed somewhere over a period of 10 years, then dumped into the well in a single episode. After that the well was likely capped. Based on the age range of the artifacts all of this appears to have taken place at a time of changing disposal patterns, when municipal refuse collection and disposal services were becoming commonplace. This would also have been a time when many people, especially rural residents, still clung to old habits of saving containers such as bottles, jars, and cans for some future re-use. That lingering habit of saving is reflected in the well fill. 


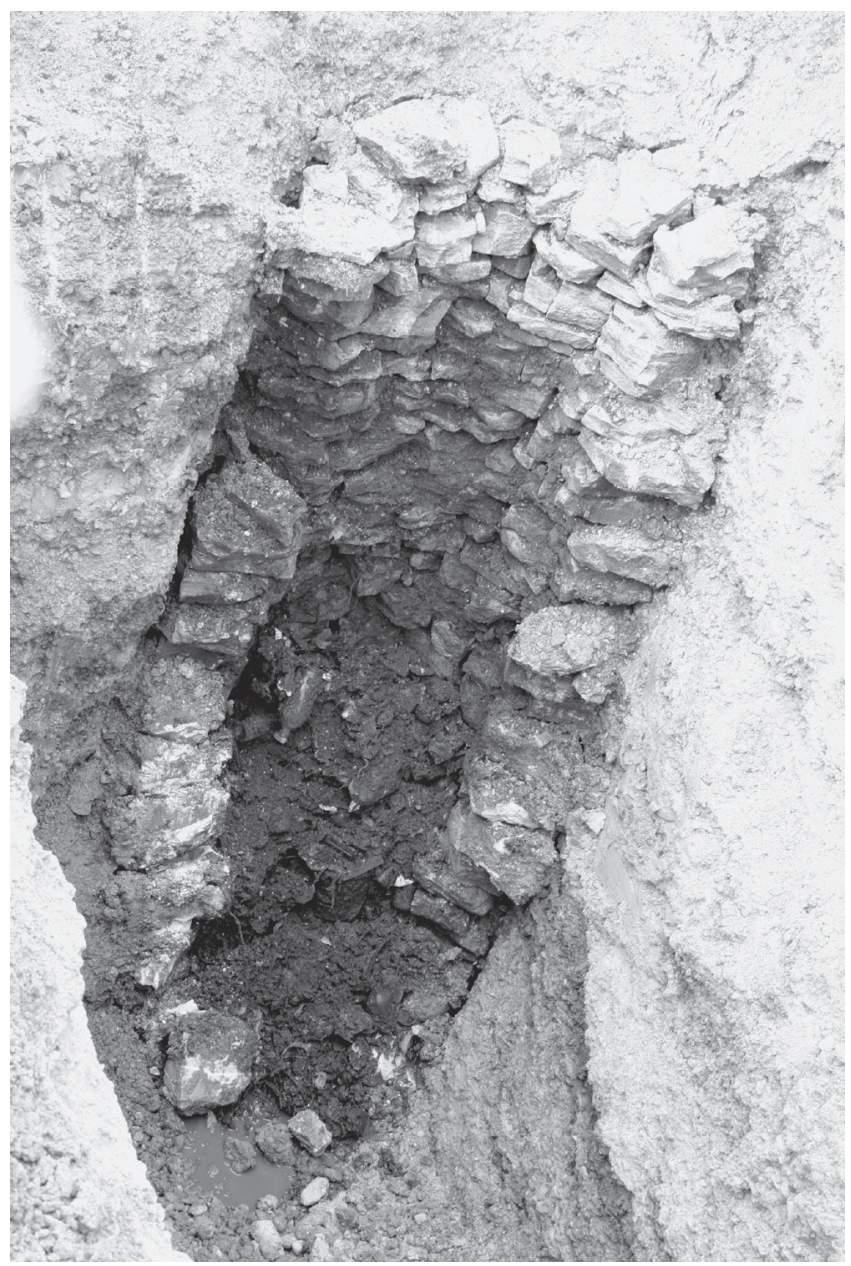

Figure 9. Bisection of well to bottom; note depth of trash deposit and water emerging at bottom. 



\section{Chapter 5}

\section{Artifact Analysis}

Artifacts recovered during the testing of the Engstrand Well consisted of an assemblage of 1138 individual artifacts and nearly 14 kilograms of metal scrap from activities associated with a rural domestic residence. Though the well itself most likely dates to the late 1800 s, the identification of diagnostic bottlemarks indicates that the majority of the bottles and by extension the other refuse recovered in the well dates primarily to the 1930s and 1940s. Based on the dates of the artifacts, sometime during the late 1930s the function of the well was transformed from a source of water to a location for the disposal of trash until around 1950 when it was capped and forgotten until highway construction uncovered it. The overall character of the assemblage is weighted towards activities associated with agricultural production, domestic chores such as washing and canning, and the disposal of particular kinds of kitchen trash and smaller amounts of general refuse. The short temporal period suggested by the datable artifacts suggests that the well deposit formed relatively rapidly over a span of several years or a decade.

In this section, the methodology utilized in the analysis and curation of the artifacts is presented. This is followed by descriptive overviews of the artifacts recovered by functional category, the implication for the activities represented, and the depositional processes as they relate to the formation of the well deposit. A complete specimen inventory is presented in Appendix A.

\section{METHODOLOGY}

All artifacts collected during the excavation were bagged in the field and returned to the Hicks
\& Company lab for processing. Processing consisted of washing and cataloguing all artifacts. Artifacts were divided into bulk sample groups or unique items. Bulk samples were defined as those artifacts that consisted of groups of nondiagnostic or fragmented artifacts of the same material type. Thus, all glass shards of a particular color-brown, clear, green, etcetera-that lacked bottle marks or brand information were grouped together, counted, weighed, and any other information pertaining to attributes such as finish were recorded in a separate notes field. Diagnostic artifacts were those that were complete or had diagnostic manufacturing marks. With the exception of bulk samples of metal which were only weighed, all artifacts were counted and weighed. Bulk metal samples were only weighed owing to the highly fragmented and often fragile nature of the artifacts. All information was entered into a specimen inventory in Microsoft Excel ${ }^{\circledR}$. Select artifacts were then photographed.

Artifacts were sorted based on two primary categories: functional category and material type.

\section{Functional Categories}

Functional Categories followed in the analysis consist of an expanded list of functional categories based on those presented by South (1977). The functional categories utilized in the analysis and examples of the types of artifacts associated with them include the following:

\section{Kitchen $(K)$}

Dinner plates, cups, saucers, eating and cooking utensils, pots, pans, storage containers, glass ware, 
condiment containers, tin cans, soda water bottles, extract bottles, serving vessels, stove parts, kitchen knives, coffee grinders, meat grinders, etc., liquor bottles, beer bottles, wine bottles, wine bottle seals, ginger beer bottles, liquor, beer, or wine bottle closures, etc.

\section{Grooming $(G)$}

Combs, brushes, cosmetic containers, perfume bottles, razors, shaving cups, shaving brushes, tooth brushes, tooth paste containers, etc.

\section{Clothing (CL)}

Buttons, other clothing fasteners, belt buckles, shoe buckles, button hooks, shoe grommets, shoe parts, corset stays, corset ribs, collar studs, etc.

\section{Medical (M)}

Patent medicine bottles, douche bags, contraceptive syringes, hot water bottles, ice bags, hypodermic syringes, pill boxes, dentures, Vaseline bottles, Mentholated bottles, drug store bottles, prescription bottles, etc.

\section{Education/Communication (EC)}

Pens, pencils, pen nibs, pencil eraser ferrules, slates, slate pencils, chalks, ink bottles, etc.

\section{Recreation $(R)$}

Game pieces, dolls or doll parts, tea set pieces, clockwork tin toy parts, cast iron toy parts, marbles, golf club parts, pool table parts, etc.

\section{Activities (Ac)}

Dog tax tags, personal I. D. tags, religious medals, military medals, rosaries, machine oil bottles, bluing bottles, safety pins, laundry clips, needles, thimbles, darning needles, crochet needles, fishing tackle, fishing weights, etc.

\section{Tobacco (To)}

Smoking pipe bowls, pipe stems, snuff bottles, tobacco tins, pipe tools, tobacco tags and seals, etc.

\section{Architecture (Ar)}

Cut nails, wire nails, window glass, door hinges, door locks, water pipes, sewer pipes, copper wire, porcelain insulators, electric switch parts, wood screws, etc.

\section{Household/Furniture (HF)}

Lamp parts, lamp chimneys, lamp shades, oil reservoirs, electric light bulbs, gas lamp parts, ornamental ceramics, ornamental figurines, ornamental glass, sad irons, padlocks, furniture hinges, furniture knobs, drawer pulls, casters, marble top fragments, escutcheons, etc.

\section{Tools $(\mathrm{Tl})$}

Hammers, saws, chisels, plane knives, drill bits, files, wrenches, screw drivers, draw knives, carriage bolts, machine bolts, machine screws, nuts, etc.

\section{Transportation (Tr)}

Trace hardware, horseshoes, buckles, cinch rings, spurs, harness buckles, leather straps, whiffletree clips, buggy parts, wagon parts, wheel parts, wagon wheel wrenches, automobile parts, luggage hardware, gasoline cans, etc.

\section{Dietary $(D)$}

Eggshells, food related bones of fish, fowl, beef, pigs, oyster shells, clamshells, peach pits, nutshells, seeds, etc.

\section{Miscellaneous (Mi)}

Prehistoric artifacts, mineral samples, modern or unidentified items.

Following an overview of material types, artifacts are described by their functional categories and their significance to the types of activities to which they relate in a separate section below.

\section{Material Types}

Material types recovered during the course of the Engstrand well included the following: 
1. Glass

2. Ceramic

3. Metal

4. Synthetic (any synthetic material such as vinyl, rubber, etc.)

5. Composite (artifacts that consisted of at least two different material types)

6. Mineral

7. Bone

As can be noted in Table 1, the most common material type recovered in terms of both count and weight was glass followed by metal. As previously noted, however, not all metal artifacts were counted, thus their absolute number is underrepresented in that category. Comparison of the weights illustrates that metal artifacts were more common than the count suggests. This table also makes clear that other material types were poorly represented in general. This is particularly true of bone, for which only a single example was recovered. If the well was being utilized as a more general refuse pile associated with household activities, we would anticipate that a greater quantity of bone would be recovered. The lack of actual food remains supports the position articulated throughout this section that the well served as a location for the disposal of distinct types of trash associated with particular types of activities-agriculture, automotive maintenance, disposal of "hazardous" materialsrather than as a primary trash disposal location for the site inhabitants.

\section{Curation}

Through an agreement made between Hicks \& Company, TxDOT-ENV and SHPO (letter dated April 12, 2007, see Appendix B), the following discard policy was adopted for the recovered artifacts. All artifacts of a diagnostic and unique character will be curated at the Texas Archeological Research Lab. All artifacts that are non-diagnostic or redundant examples will not be curated and discarded at the discretion of TxDOT and Hicks \& Company. A complete inventory of all artifacts collected and their final discard status is provided as Appendix A in this report. Artifacts retained for curation have been assigned a unique item number, labeled and curated in the appropriate format as stipulated by the Texas Archeological Research Laboratory (TARL) curation standards.

\begin{tabular}{||l|c|c||}
\hline \multicolumn{1}{|c|}{ Table 1 } & Artifact Recovery by Material Type & Weight (g) \\
\hline Bone & Count & 10 \\
\hline Ceramic & 1 & 4114 \\
\hline Composite & 60 & 1080 \\
\hline Glass & 14 & 30851 \\
\hline Metal & 857 & 24010 \\
\hline Mineral & 185 & 66 \\
\hline Plant & 1 & 1 \\
\hline Synthetic & 2 & 1148 \\
\hline TOTAL & 18 & 61280 \\
\hline
\end{tabular}




\section{ARTIFACT OVERVIEW BY FUNCTIONAL CATEGORY}

In this section a summary of the artifacts by functional category is provided. As illustrated in Table 2, the most common functional category represented by the artifacts is the kitchen category followed by architecture, household/ furniture, activities, grooming, medical, clothing, dietary and education. The most noteworthy aspect of functional categories represented by the artifact assemblage is the overwhelming number of kitchen related artifacts in relation to other categories.

\begin{tabular}{|c|c|c|}
\hline Table 2 & Artifact Recovery by Functiona & \\
\hline Functional Category & \begin{tabular}{r|r} 
& Count \\
\end{tabular} & Weight (g) \\
\hline Activities & 27 & 4907 \\
\hline Architecture & 90 & 452 \\
\hline Clothing & 2 & 103 \\
\hline Dietary & 1 & 10 \\
\hline Education & 1 & 107 \\
\hline Grooming & 13 & 1443 \\
\hline Household/Furniture & 68 & 1385 \\
\hline Kitchen & 848 & 43548 \\
\hline Medical & 18 & 879 \\
\hline Recreation & 1 & 73 \\
\hline Tobacco & 1 & 6 \\
\hline Tool & 16 & 3496 \\
\hline Transportation & 29 & 3519 \\
\hline Unknown & 23 & 1281 \\
\hline Total & 1138 & 61280 \\
\hline
\end{tabular}




\section{Activities}

Twenty-seven artifacts were classified as belonging to the functional category of activities. This category was predominately composed of three complete bottles and 21 fragments of Hi-lex bleach containers (Figure 10). All of the bottles and fragments were brown glass manufactured by the Owens-Illinois glass company, and were found in both gallon and half gallon sizes. Of the three examples of bottle marks, all bore marks indicating the date of bottle manufacture as 1946 . Clearly these artifacts reflect the use of bleach in the laundering of clothing, and perhaps other cleaning activities.

The remaining artifacts consist of several poorly preserved metal cans and fragments and a mass of thread or string. One of the better preserved metal containers is circular metal tin that held flux for soldering. The writing on the tin identifies the manufacturer as Divco (Figure 10). In addition, four metal buckets of varying sizes were recovered. The mass of thread may be sewing thread or string, but it is too poorly preserved to determine. The metal can has red and black paint and retains the following visible writing: "polish with... strokes, rubbing until dirt film... Restore original...". This artifact appears to be a polish compound, though for what purpose is unclear. Also recovered in the well but not collected due to the likely toxic nature of the contents, was a rusted metal container of stain or turpentine. When recovered the artifact was still sealed and no brand identification was legible, but it continued to emit a strong odor of turpentine or other solvent. Additionally three fragments of metal

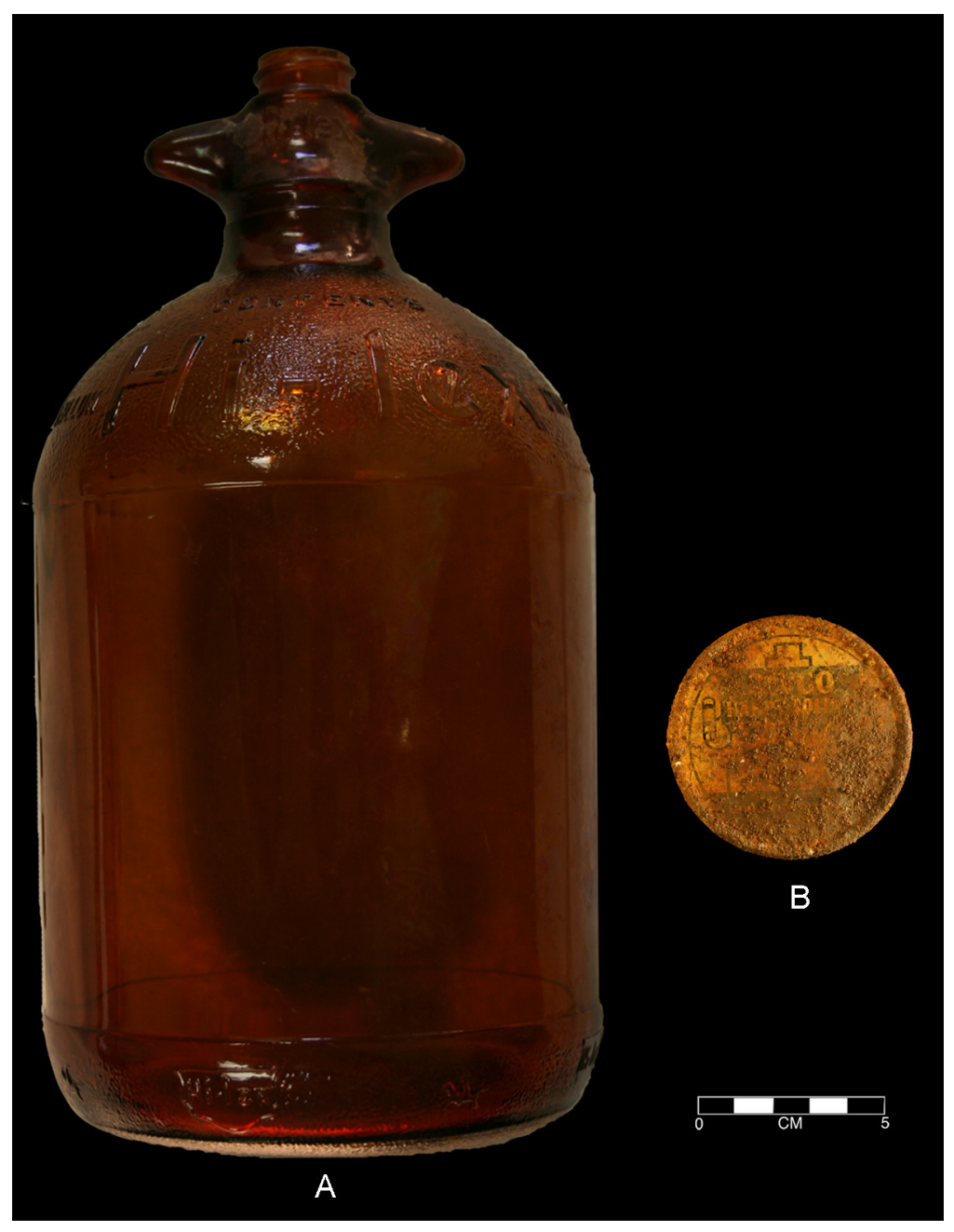

Figure 10. Activities Artifacts Recovered from the Enstrand Well: (A) HiLex Bleach Bottle and (B) Divco Solder Container 
cans with double friction lids typical of those found on paint cans were also recovered. Taken together these items likely indicate that other rusted and indeterminate metal artifacts may be other cans of paint or materials for house care.

\section{Architecture}

The recovery of architectural elements was relatively restricted. With the exception of 10 pieces of clear window glass, a chunk of concrete, a fragment of ceramic pipe and piece of wire fencing, the remaining 77 artifacts in this functional category were nails. The nails ranged in size from 1.5 to 4 inches in length, and reflected a variety of uses including generalized construction nails and small thin finishing nails. All nails recovered were manufactured using a pulled wire method.

\section{Clothing}

Only two pieces of clothing were recovered: a shoe heel and a white plastic belt.

\section{Dietary}

Only one piece of bone was found during the excavation. It was burned and has not been analyzed as to species. The overall lack of bone in the well is interesting, suggesting that the Engstrand well did not serve as a trash dumping location for food remains. This is perhaps because it was not physically close to the kitchen area or that the food remains were being collected, burned or disposed of in some other manner.

\section{Education}

The category of education was represented by the recovery of a single ink bottle (Figure 11). The bottle is made of clear glass with an externally threaded finish and a small reservoir on the interior below the neck. Using the patent and manufacturing information on the base ("PAT D 1759866"; a "16" in a circle), this artifact was identified as a container for Sheaffer Skrip Ink. Based on the bottle markings and the periods of production of the ink, the artifact dates no earlier than 1945.

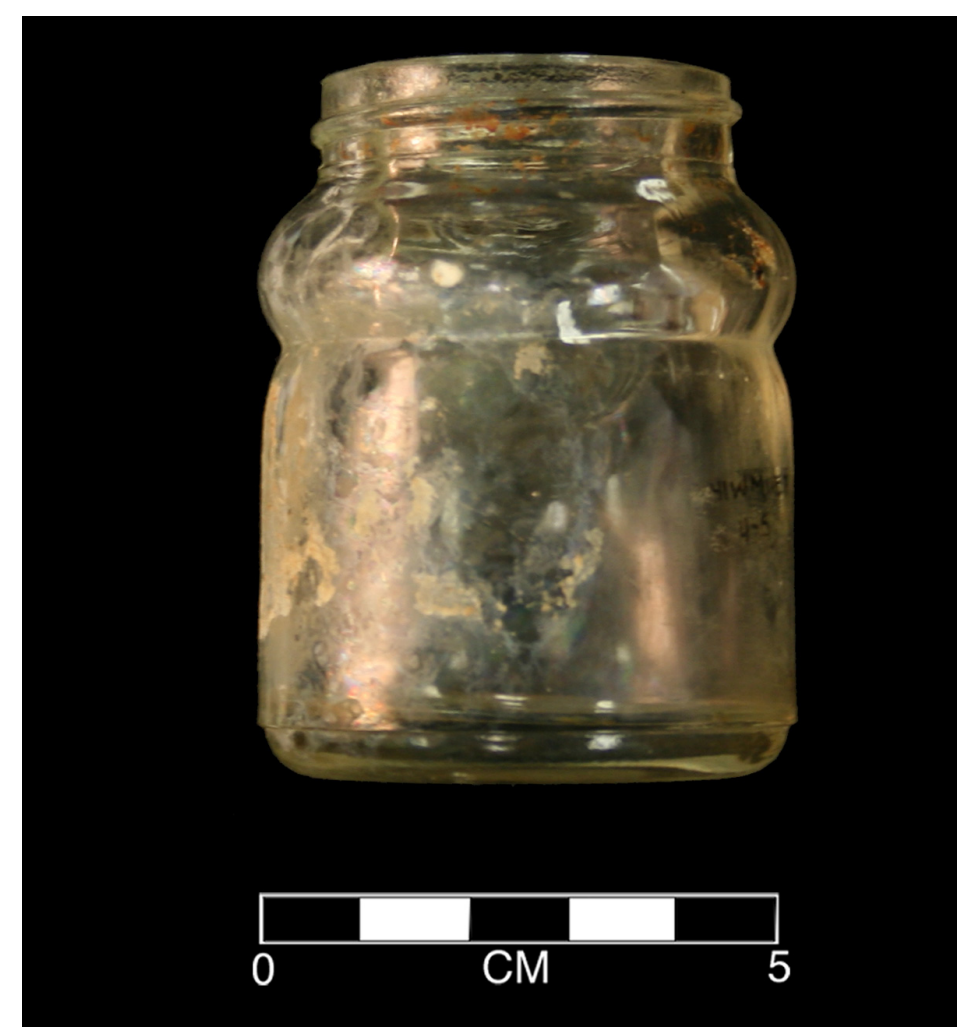

Figure 11. Sheaffer Skrip Ink Bottle. 


\section{Grooming}

Artifacts functionally related to personal grooming or care numbered 16 (Figure 12). These included three complete milk glass jars (two with lids) and five fragments. The two jars with lids had faint writing that was identified as reading "Chas A. Phillip." Research was able to establish that these two jars held Phillip's Cleansing Cream, a product made by the manufacturers of Phillip's Milk of Magnesia utilizing milk of magnesia. This product was sold during the 1930s and 1940s. Presumably the other milk glass jars held the same or similar products. A fragment of a rectangular clear glass bottle embossed with "Jergen's Lotion" was identified as another grooming product. A complete clear bottle marked with the "Revlon" brand name appears to be a bottle of nail polish. A second complete frosted jar with its metal cap intact and a pink colored substance inside has been tentatively identified as a makeup (foundation?) or cream. Another complete clear glass bottle with a narrow diameter hole in the top may have held hair tonic or cologne. It had a bottlemark on the base reading " 52 ," but this mark could not be linked to a manufacturer. Finally, four similar bottles from three different manufacturers were found that based on their shapes are believed to be cologne or perfume bottles. All the bottles are ovoid in cross section with large to small vertical ribs on the front and back. Two of the bottles are manufactured by the Swindell Bros. (1869-1959) (Toulouse 1971); one was manufactured in 1946 by Owens-Illinois, and the fourth by the Knox Bottle Co. (1932-1953) (Lockhart 2004b).

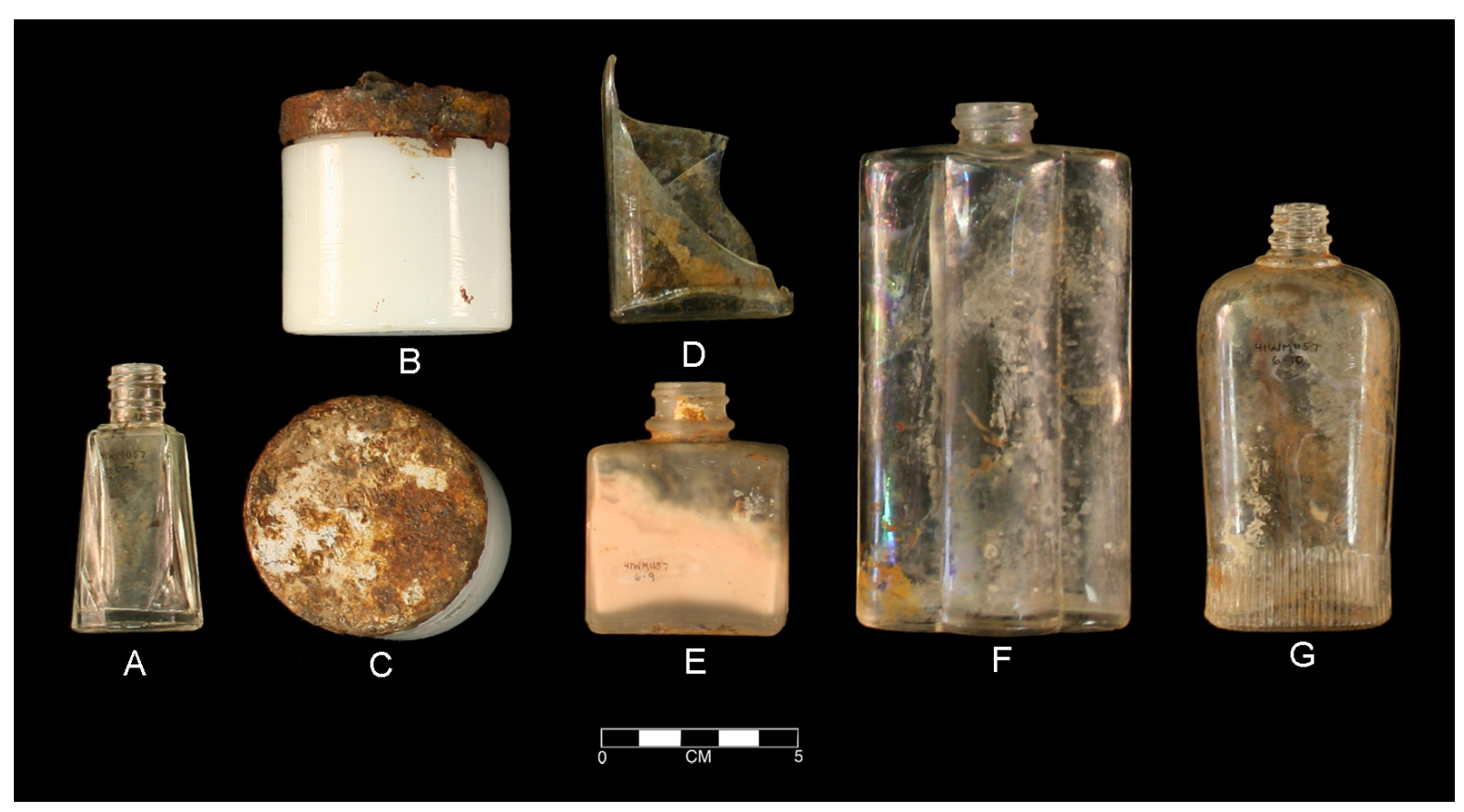

Figure 12. Various Grooming Related Artifacts Recovered From the Engstrand Well. 


\section{Household}

Sixty-eight artifacts were identified during the analysis as items associated with household furnishings (Figure 13). These included 31 fragments of flowerpots and one complete flower pot. At least three different pots are represented in the collection. One of these is a light beige terracotta pot. Another is a thick whiteware with a yellowish glaze and a molded leaf decoration glazed green. The final flower pot is a small 3" tall starter pot. Though identified as "household" items, these flower pots are just as likely to have been situated outdoors.

Other household related items include four light bulb bases and 23 pieces of light bulb glass. Four pieces of very thin curved blue glass were recovered that may be part of a colored light. Another five pieces of molded glass, likely lampshade fragments or pieces of decorative glass items rounded out the collection.

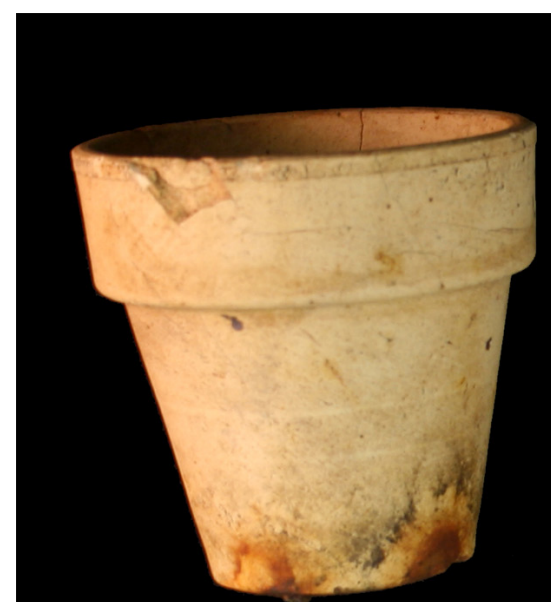

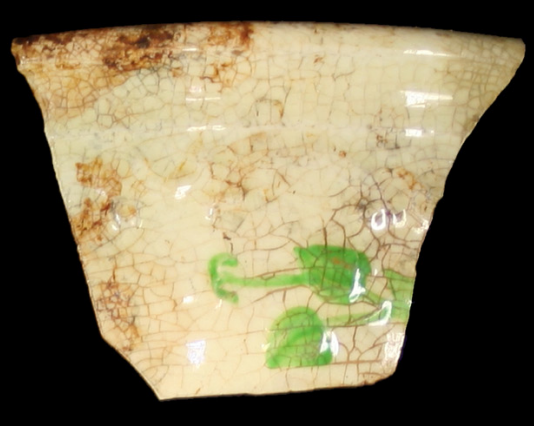

B

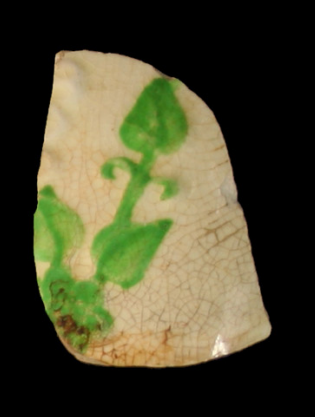

C

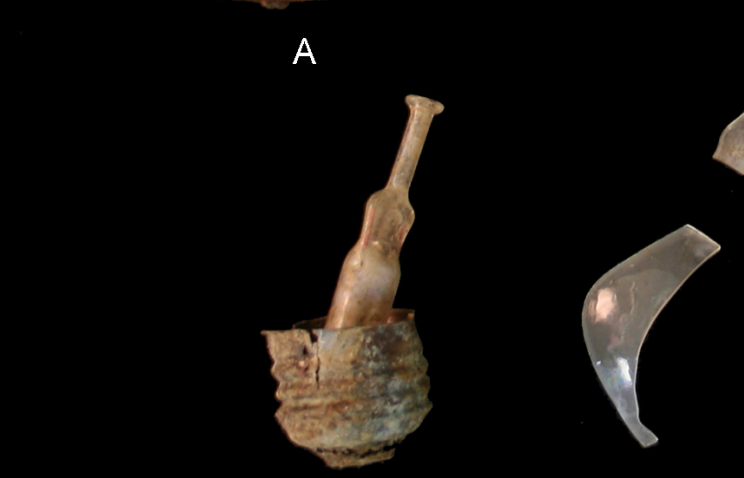

D
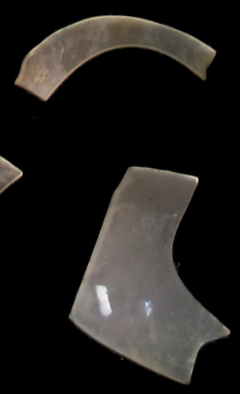

E

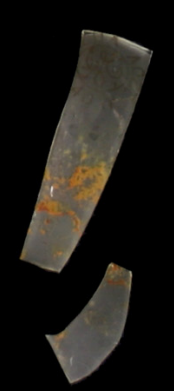

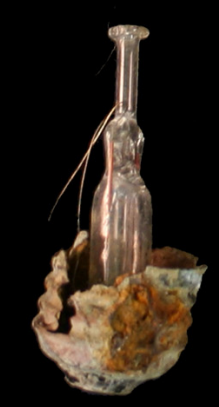

F

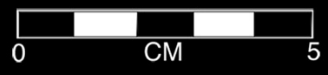

Figure 13. Various Household Artifacts Recovered From The Engstrand Well: (A-C) Flower Pot Sherds, (D,F) Light Bulb Bases, (E) Light Bulb Glass. 


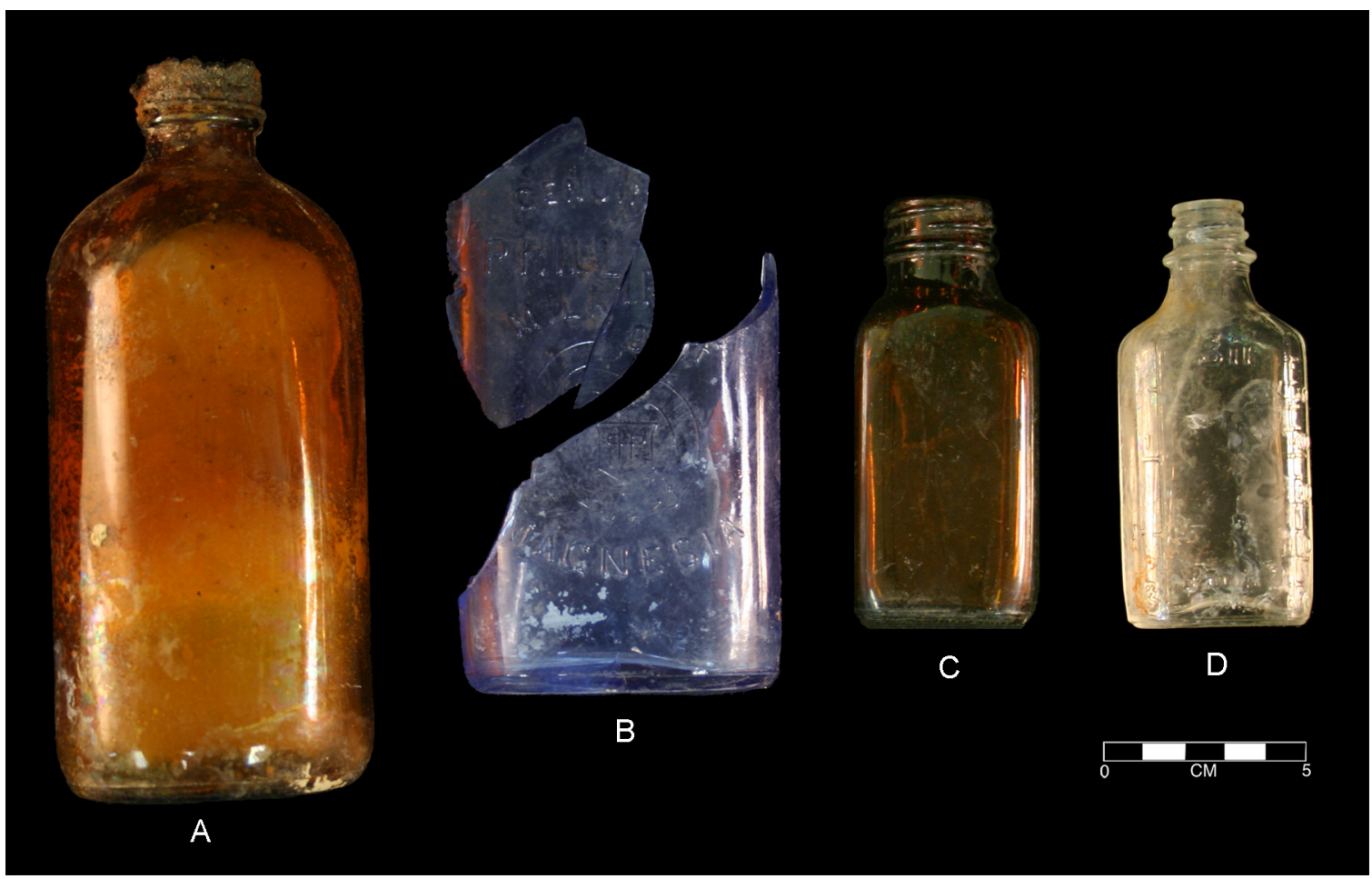

Figure 14. Various Medical Artifacts Recovered from the Engstrand Well: (A) Thatcher Manufacturing Bottle, (B) Philips Milk of Magnesia, (C) Brockway Glass Bottle (D) Owens-Illinois graduated bottle.

\section{Medical}

The recovery of artifacts related to medical type activities was represented by only 15 artifacts (Figure 14). Nine of these artifacts are blue glass shards that belong to a bottle of Phillips Milk of Magnesia. No bottlemarks were preserved relating to manufacture, but portions of the embossed side panels of the bottle were found bearing the product name. Other medical related artifacts included five complete prescription finish bottles and the neck of a broken prescription finish bottle. Examples lacking known bottlemarks include a clear $80 \mathrm{cc}$ graduated bottle and a small green bottle with a black plastic screw cap. A complete brown glass bottle manufactured by Thatcher Manufacturing Corporation (1904-1985) still retains the metal screw cap and has a white substance inside. The bottle appears to possibly be a hydrogen peroxide bottle. Another complete, brown glass medical bottle has a bottlemark indicating it was manufactured by the Brockway Glass Company sometime after 1925. This may be a cough syrup or similar type of product. A post 1940 Owens-Illinois clear graduated bottle was recovered. Finally, the neck and upper body of a small $2 \frac{1}{2} 2$ ounce bottle was recovered that also appears to have contained a medicine.

\section{Kitchen}

Artifacts assigned to the kitchen functional category were the most common. In total 849 individual artifacts were identified as kitchen related, though included in this category was a large number of tin can fragments that were only weighed which means the total count is actually higher. Nearly 44 kilograms of glass, ceramic, metal, plastic and other materials were assigned to the kitchen functional category. In part the very high number of kitchen related artifacts is due to the practice of lumping all bottle or jar glass and tin cans that lack identifying marks as kitchen-related. However, the more intact artifacts - primarily glass and metalare nonetheless clearly associated with items that would have been kept or utilized in the kitchen, and these are a large portion of the assemblage.

Perhaps one of the most interesting aspects of the assemblage was the high number of canning 
jars and vinegar bottles that strongly indicate that the canning of vegetables was a regular practice for the residents of the property (Figure 15). Among the kitchen materials, 61 whole jars or fragments were identified as likely canning jars. Six of them bore embossing that read Ball, the most common producers of canning jars, and one bore the embossed name of Kerr, another mass producer of canning jars. It is assumed that other unlabeled jars with wide mouths and external threaded finishes are likewise canning jars. This assumption receives at least partial tangential support from the recovery of nine clear bottles that are typical of vinegar bottles. In addition several fragments bore similar produced by the Sandahl Bottling Company in Austin, Texas.

Much of the kitchen assemblage includes metal cans or containers (Figure 17). With the exception of several different Folgers Coffee cans, most cans lacked any distinguishing marks and could not be identified as to their original contents. Owing to a change in the patterns of the capitalization of the Folgers name in 1953 when only the "F" was capitalized, we can identify these Folgers cans with their product name in full capitals, to pre-date this period. Other identifiable types of cans were several examples of spice or possibly cocoa cans. These cans were rectangular in form with circular open-

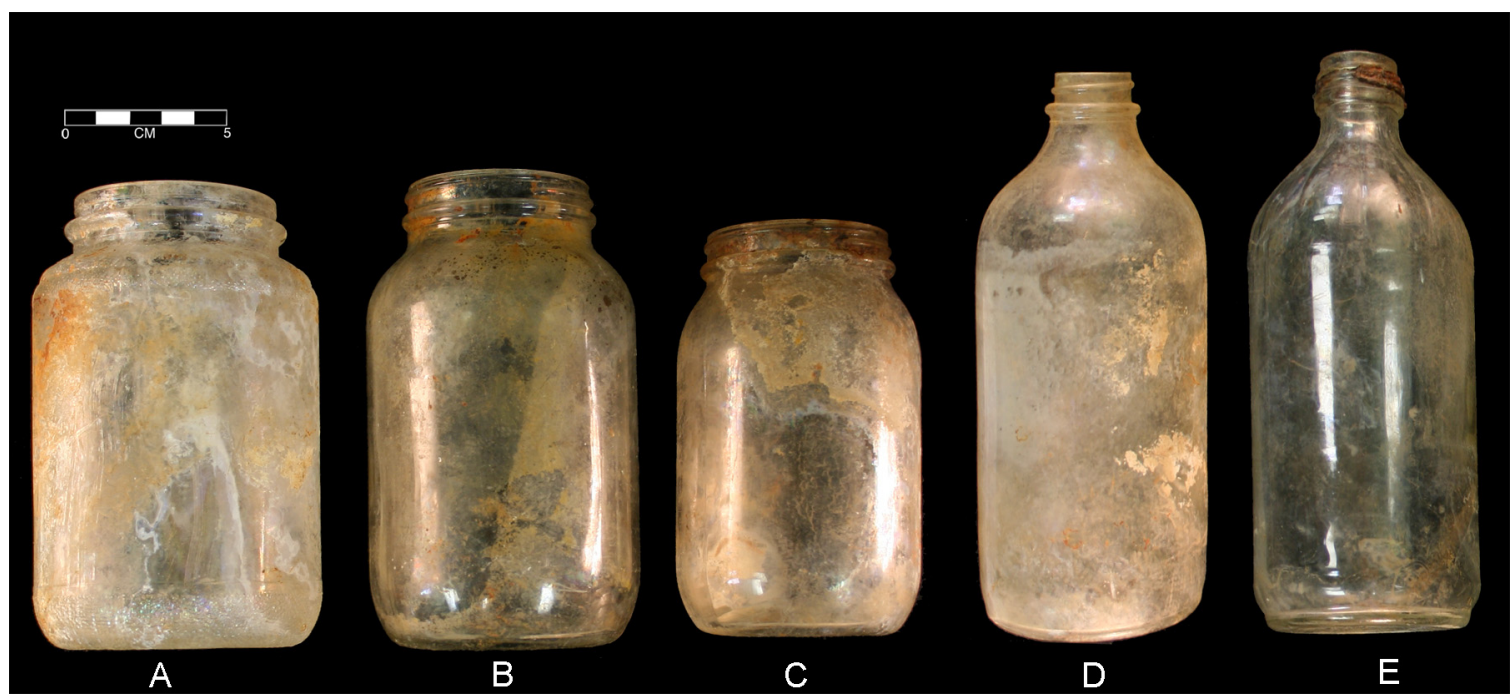

Figure 15. Kitchen Artifacts Recovered From Engstrand Well: (A-C) Canning Jars, (D-E) Vinegar Bottles.

shapes and were likely vinegar bottles as well. As vinegar is an essential ingredient in the preparation of canned vegetables or fruit, the likelihood that the residents were engaged in the pickling or canning of vegetables or possibly fruits seems very good.

In addition to large numbers of canning jars and vinegar bottles, several different condiment bottles or flavoring bottles were also encountered (Figure 16). Identifiable condiments included seven ketchup bottles, three mustard jars and a pepper sauce bottle. Flavoring bottles included an intact vanilla extract bottle and a bottle embossed with the "Hires" logo, likely a root beer flavoring. Other bottles of interest included at least two soda bottles that had screen printed designs that identified the contents as SunTex soda, a beverage ings in the top. Some were simply round holes with removable lids. Others had movable tops that could be manipulated to dispense the product directly through a large hole, or by shaking the contents. This latter form seems very likely to be pepper or a similar spice.

Many of the other round cans may have held fruits or vegetables and some of the rectangular metal containers are a shape that typically would have held sardines or potted meats. Though there is ample evidence that home canning and traditional food preparation was a regular practice of the residents (based on vinegar bottles, canning jars, and spice jars), nonetheless, foods such as coffee, potted meats, and canned fish would have been purchased from a local grocer and represent 


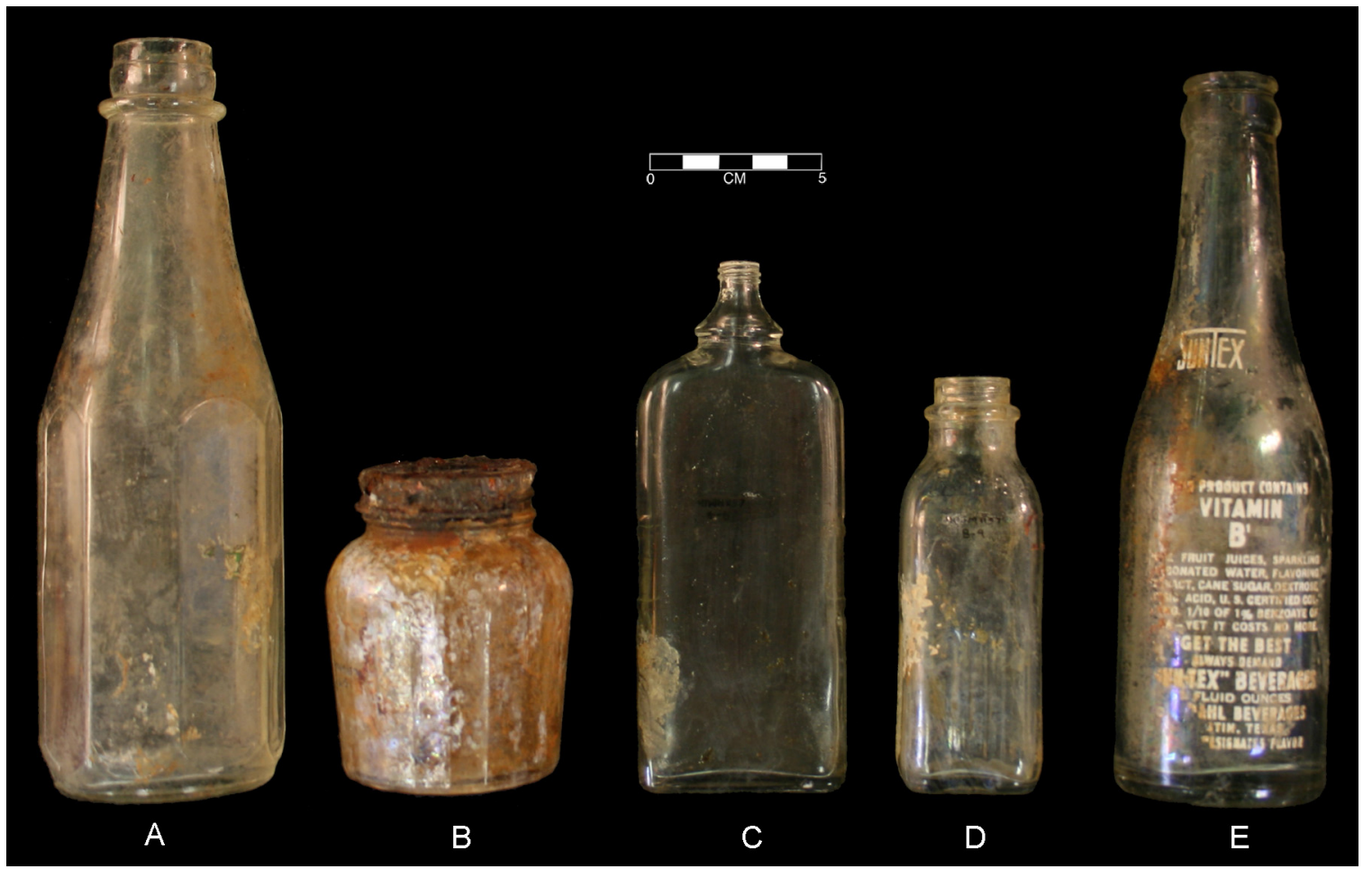

Figure 16. Kitchen Artifacts Recovered From the Engstrand Well: (A) Ketchup Bottle, (B) Mustard Jar, (C) Possible Flavoring Bottle, (D) Hires Flavoring Bottle, (E) Sun Tex Soda Bottle.

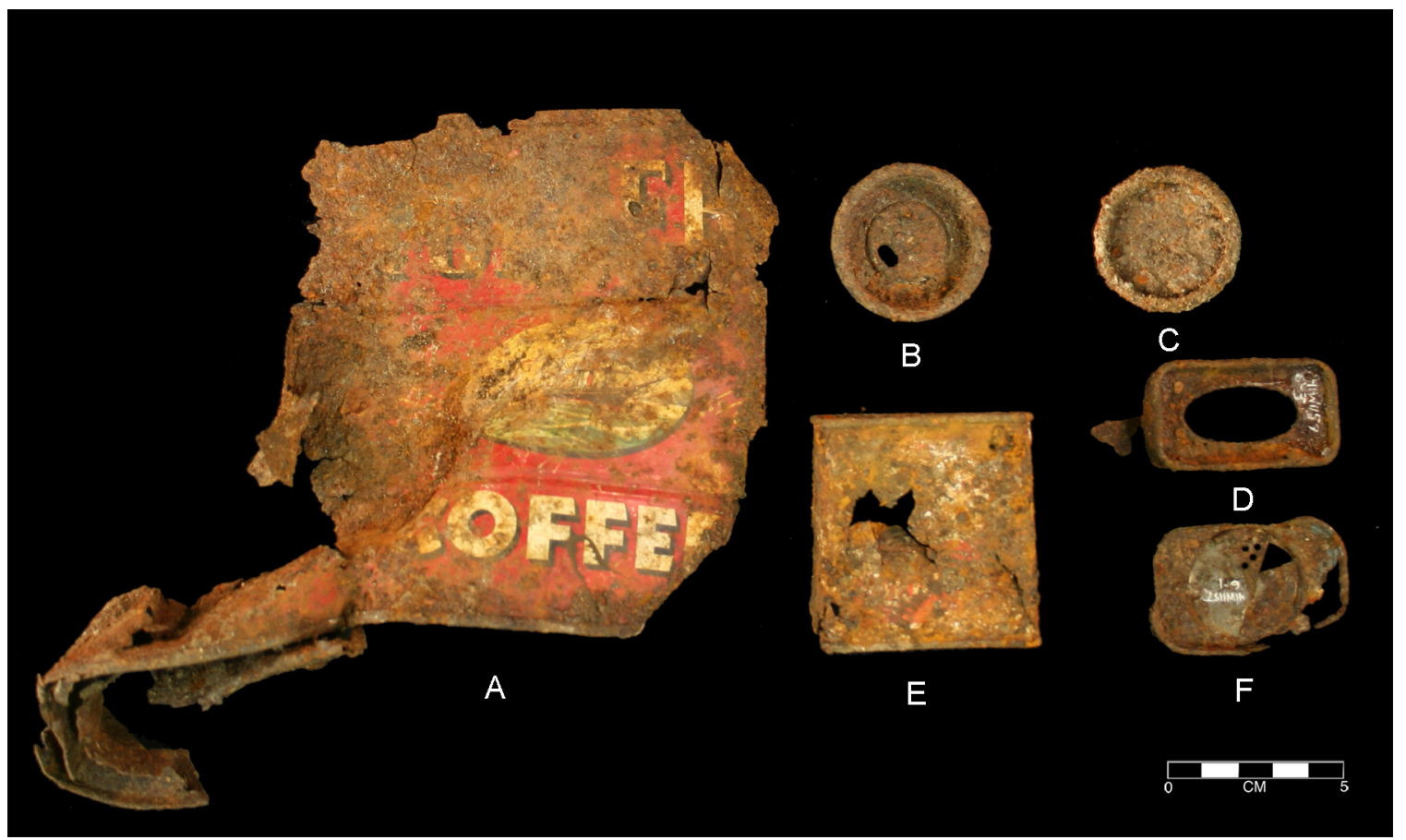

Figure 17. Kitchen Artifacts Recovered From the Engstrand Well: (A) Folgers Coffee Can, (B-F) Spice Containers and Lids. 
ready-to-eat foodstuffs more reflective of contemporary food preparation and procurement practices.

Several pieces of dinnerware were also included in the kitchen materials (Figure 18). A total of 24 pieces of whiteware dishes were recovered. Based on the form, five pertained to plates, six to bowls, 12 were cup fragments and one was a rectangular container. Two plate sherds had maker's marks indicating that the plate was produced by the Homer Laughlin and was part of the Ovenserve line. This type was being produced between 1933 and the early 1950s (Lehner 1988). In addition, a single complete white glass saucer was also recovered. Several shards of glasses were also recovered. These lacked diagnostic marks, but were decorated with silk screened colored dots. Finally a fork and a spoon were both found.

A final interesting artifact of unknown function that is classified under Kitchen is a squat stoneware container with a large screw top lid (Figure 19). The vessel has "J-615" engraved on the side, but no other maker's marks are visible. The vessel definitely is a container, but its contents have not been determined based on analysis of vessel size, material, shape, or the single alpha-numerical mark.

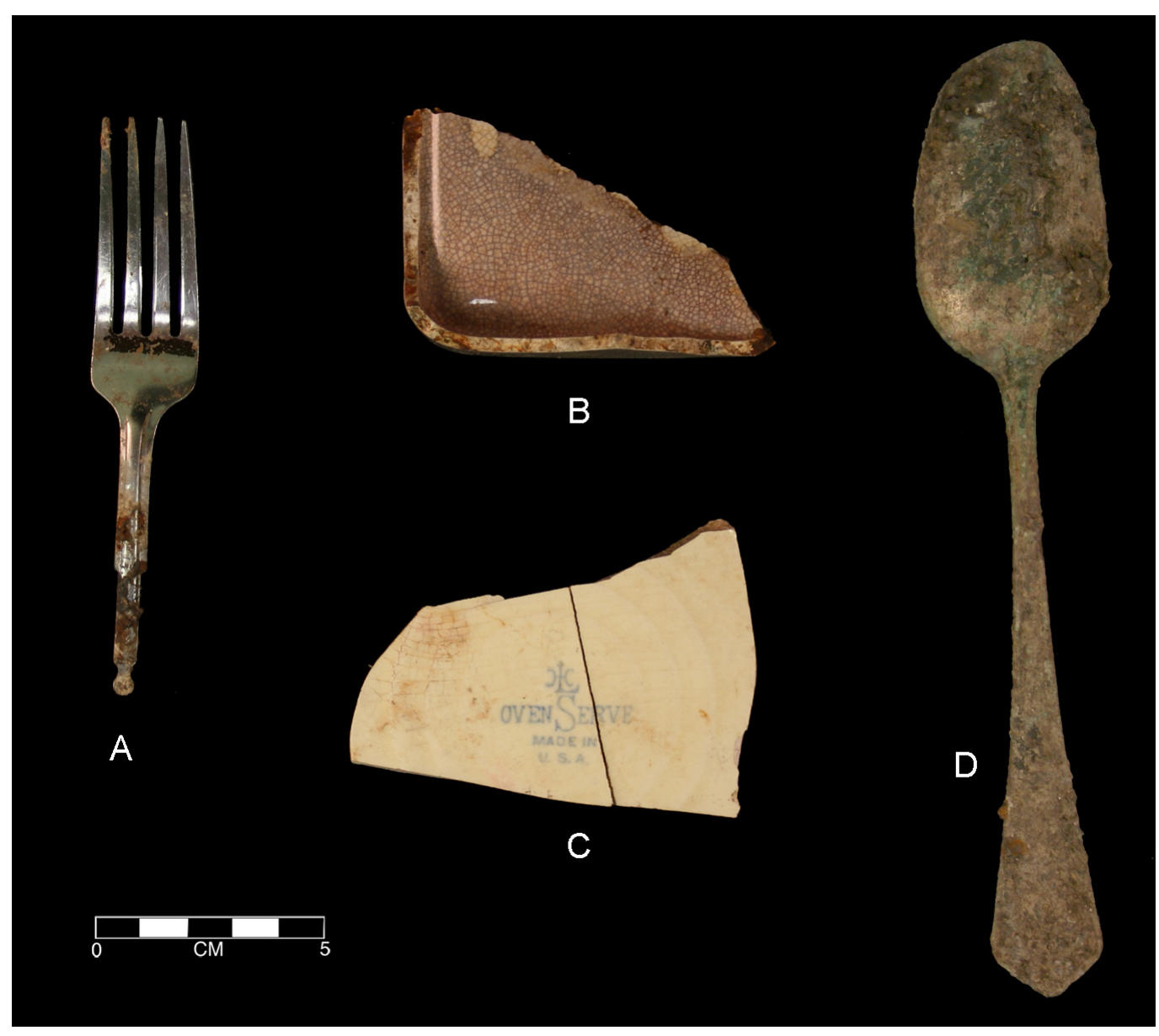

Figure 18. Kitchen Artifacts Recovered From Engstrand Well: (A) Fork, (B) Rectangular Ceramic Container, (C) Homer Laughlin Ovenserve Plate Fragment, (D) Spoon. 


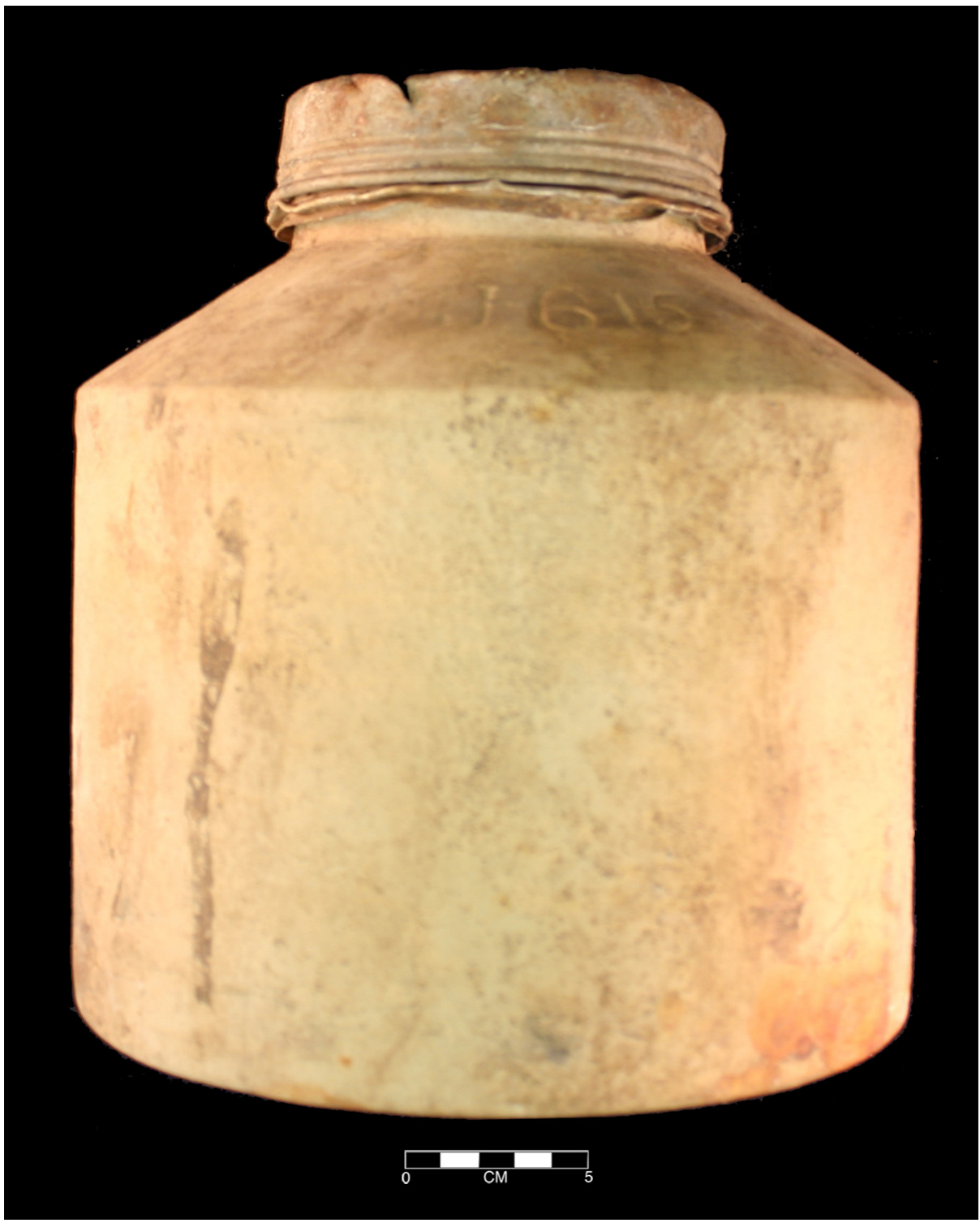

Figure 19. Kitchen Artifacts Recovered From Engstrand Well: Stoneware container with screw top lid.

Further testing of the residue may be possible to ascertain the vessel's contents, but such analysis was outside the scope of this project, and largely unnecessary for interpretation and conclusions. The material type is often associated with whiskey jugs, but the form of the vessel seems inappropriate, and it may have held pickled food or a liquid. Though the artifact has been placed in the kitchen category, it is not unlikely that the container may have served a different purpose such as holding kerosene or gas or other liquid with an application outside of a kitchen context. 


\section{Recreation}

The only artifact recovered that could be loosely tied to recreation activities was a broken semi-porcelain figurine of Minnie Mouse and Pluto (Figure 20). In the figurine Minnie is seated on a couch with Pluto at her feet and is presumably sitting with Mickey Mouse, though all that remains of her companion are his feet and a hand. The artifact has the following information stamped on the base: "...AIEY JAPAN S335".

\section{Tobacco}

A single rectangular pry off lid was tentatively identified as being the top to a tobacco tin. There were no other artifacts recovered that appeared to be related to tobacco use.
Tool

The category of tools was represented by 16 artifacts. In this category were a single size D battery, four metal buckets, two metal files, two pieces of metal wire, a plastic washer, a metal washer, a metal nozzle and four pieces of black rubber hose. Though not collected in the excavation levels and not included in the artifact counts, a large metal milk container was also recovered during the excavation of the well (Figure 21). This artifact, as well as the buckets, are all likely related to dairy farming and other agricultural activities occurring on the property.

\section{Transportation}

A total of 29 artifacts were recovered that related to transportation activities (Figure 22). The

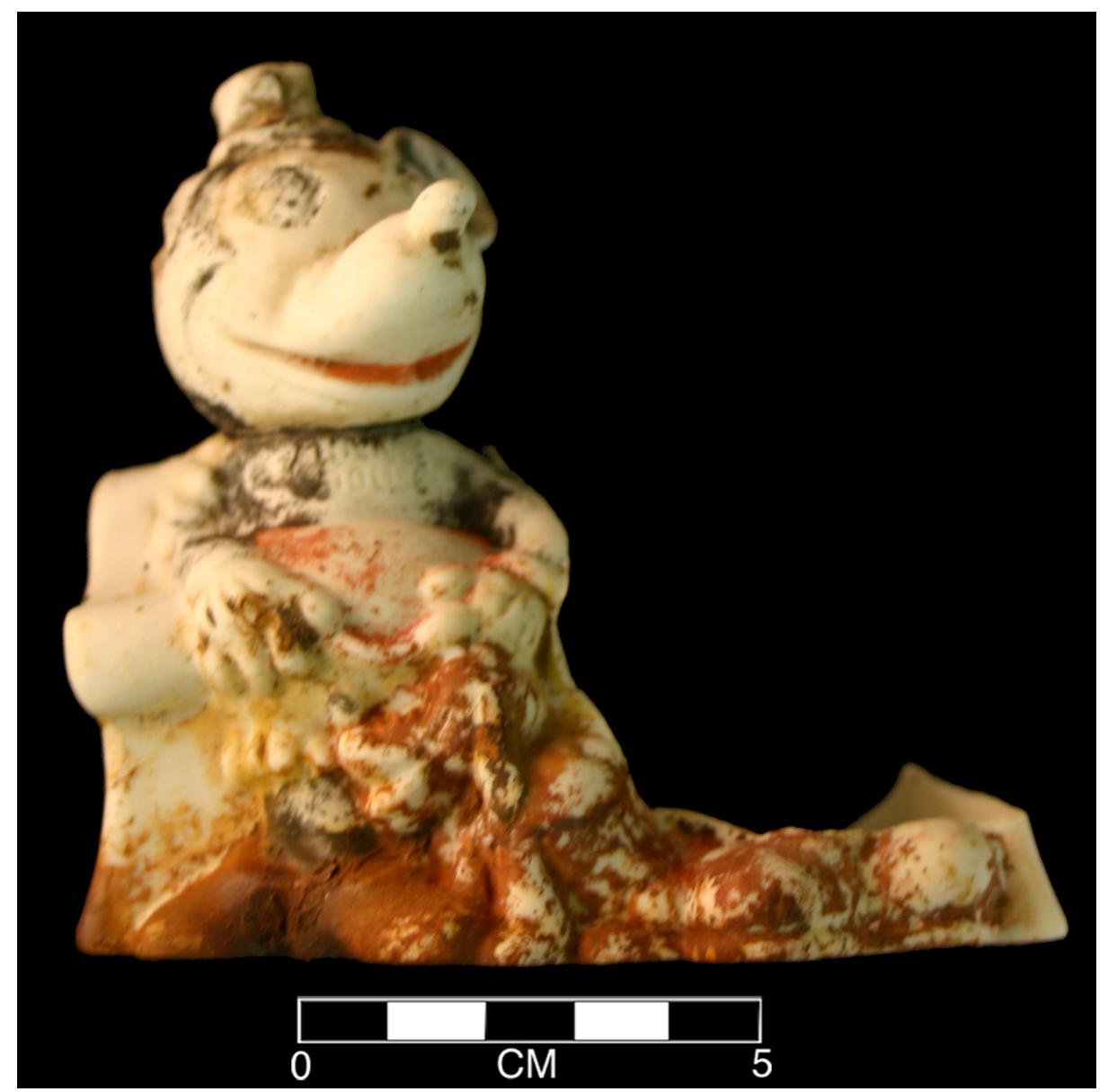

Figure 20. Minnie Mouse Figure Recovered from the Engstrand Well. 


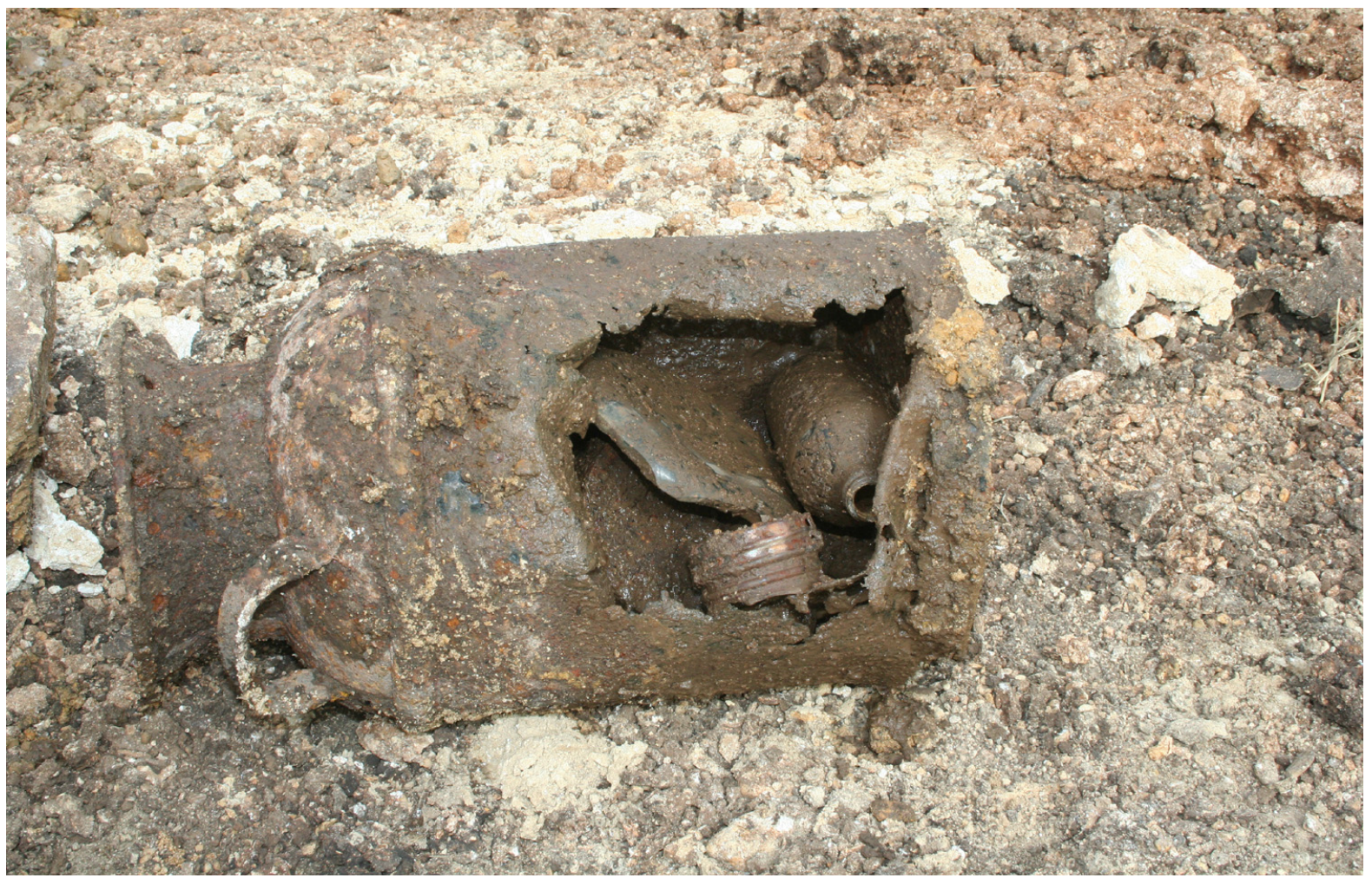

Figure 21. Photo of Metal Milk Container Collected From Bottom of the Engstrand Well.

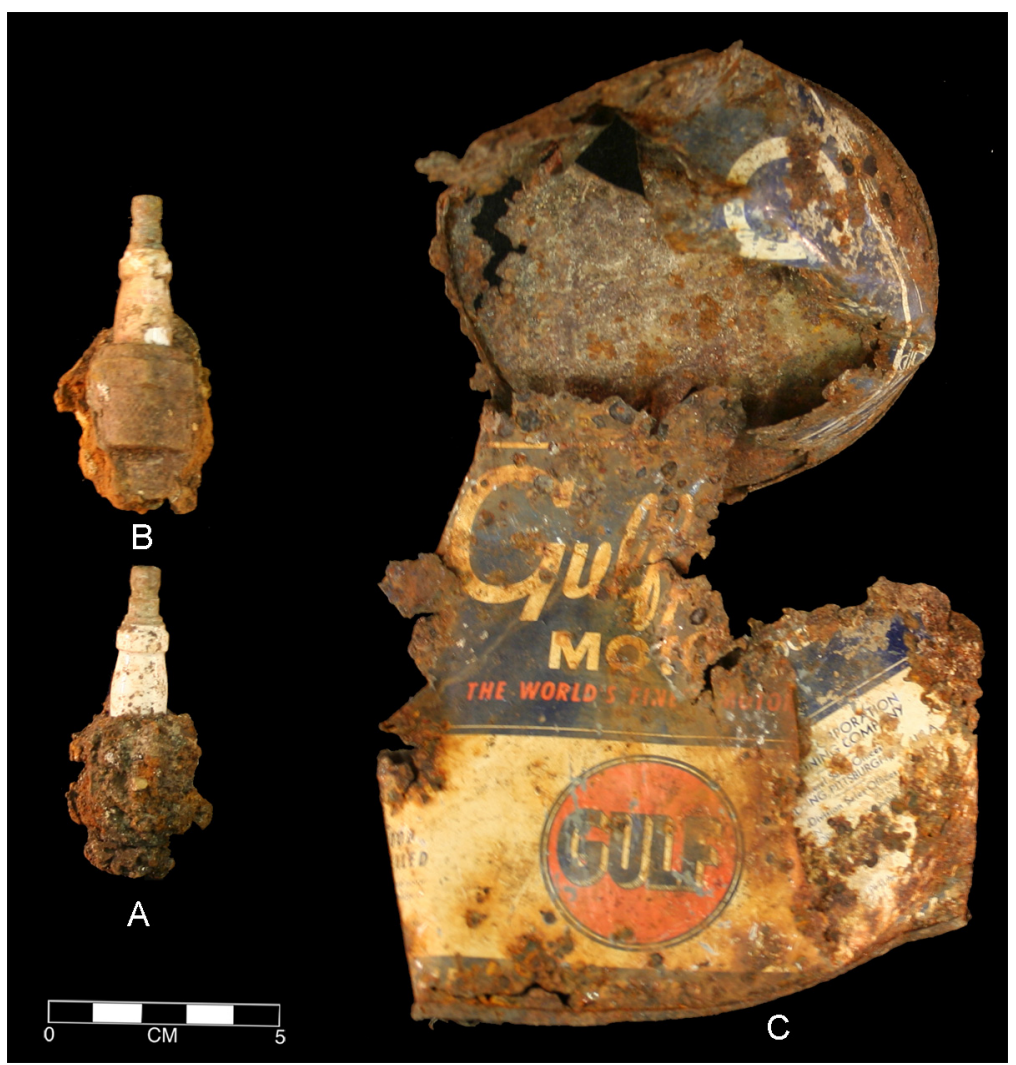

Figure 22. Transportation Related Items Recovered From Engstrand Well: (A,B) Sparkplugs, (C) Gulf Pride Motor Oil. 
most numerous artifacts were 16 cans of Gulf Pride Motor Oil. No doubt, more fragments of the cans are likely to exist in the unidentified metal fragments. From the better preserved cans it can be discerned that the oil was a single weight 10/10W. Multiple weight oils are common today, except for use in lawnmowers and some other types of nonautomobile engines. The presence of a tractor seat in the artifact assemblage (Figure 23) may indicate the oil was used for a tractor, though eight license plate fragments were also found. The eight pieces of a Texas license plate, perhaps from two plates for the same vehicle given repetition in the numbers, are likely from a personal car or truck. Reconstruction of several smaller fragments of the upper right hand corner identifies the plate as a Texas license plate from 1947. This date is consistent with dates of bottles recovered in the well. Other artifacts clearly applicable to the functioning of vehicles were three spark plugs or spark plug fragments and a metal fuel container. Once again, it is not clear if these were utilized in a tractor or a car. Given the rural location of the well, the use of the property for agriculture and the presence of the license plate, either explanation has equal validity and clearly the well was utilized to discard objects associated with vehicle maintenance.

\section{Unknown}

Twenty-three artifacts were recovered that, because of their generic nature or poor state of preservation could not be identified or assigned to a functional category. Among these artifacts were a piece of white paper, a piece of brown paper, four pieces of black rubber, five pieces of wire, a metal spike, seven miscellaneous pieces of metal, an indeterminate metal machine part, an indeterminate broken glass tube, a black plastic cover and a white mineral-perhaps chalk or lime.

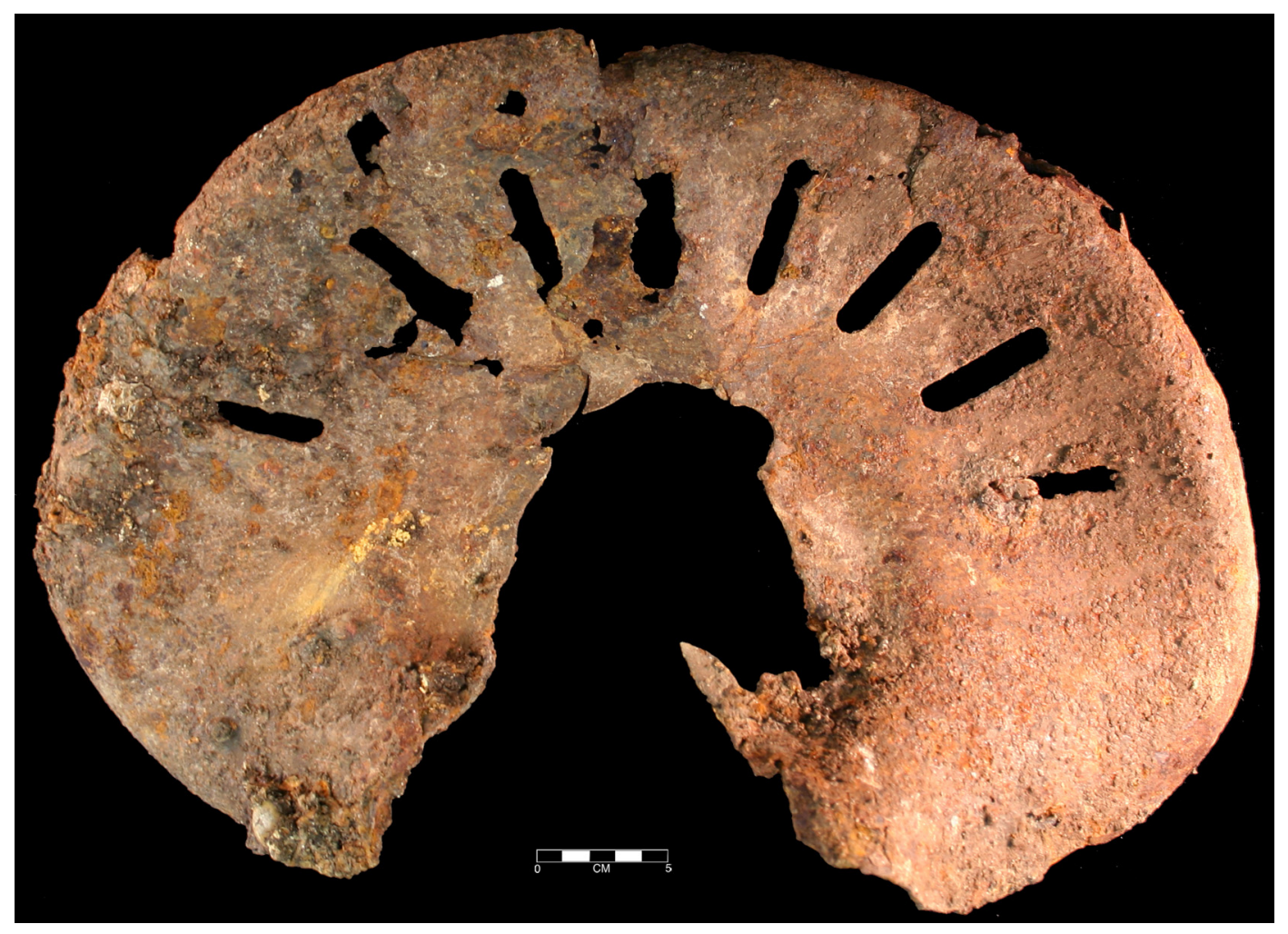

Figure 23. Tractor Seat Recovered From Engstrand Well. 


\section{DATING THE DEPOSIT}

Though the well itself is likely to have been built in the latter decades of the nineteenth century, based on construction technique and materials, the trash deposit is considerably later in date. Though much of the material cannot be precisely dated, bottles provided the best means of dating the deposit. Several lines of evidence clearly indicate that the artifacts were manufactured primarily during the 1930s and 1940s. At the most general level it was observed that all the glass recovered in the well was manufactured using automatic bottle machines which post date 1906, and all the clear glass lacked the purple discoloration commonly associated with manganese bleaching, a process which was replaced by selenium and arsenic bleaching by the 1920s. Bottlemarks were especially useful in dating the assemblage. Though a large number of bottlemarks were recorded and observed on the artifacts, many were used for a relatively long period of time that does not allow one to refine the period of manufacture (Table 3). For example, 28 artifacts had the Hazel Atlas bottlemark-an upper case " $H$ " with an upper case " $A$ " situated in the lower half of the $\mathrm{H}$, but this mark was utilized for a period spanning from
1923-1964. Other bottlemarks with broad temporal spans include: four Brockway bottlemarks dating from a period from 1925 to 1983, seven Knox Bottle Company marks spanning 1932-1953, four Anchor Hocking that date to 1937 to present, six Ball 19191969, two Swindell 1920-1959, two Foster Forbes 1942+, one Maywood from 1930-1959, one Kerr bottle 1909+, and one Thatcher Manufacturing 1923$1950+$. While taken together the general manufacturing techniques and the broad date ranges can basically situate the assemblage as post 1920 s, the recovery of 31 Owen-Illinois bottles or fragments provide a higher resolution of information (Table 4). As Toulouse (1971) and Lockhart (2004a) have discussed, by the 1930s the Owen-Illinois company began incorporating date of manufacture information in their bottlemarks. When looking at the bottlemark, the number to the right indicates the year in which it was manufactured. Unfortunately, because the date mark is only a single number, differentiating the decade is complicated. Though some bottlemarks have a period following the date mark-indicating the 1940s-many do not, making assignment to a particular decade problematic.

Two additional aspects of manufacture can help to narrow down the date. One is the presence of the

\begin{tabular}{|c|c|c|c|}
\hline \multicolumn{4}{|c|}{ Glass and Ceramic Makers' Marks and Time Ranges } \\
\hline & Maker's Mark & Time Range & Count \\
\hline \multirow{12}{*}{ GLASS } & Foster Forbes & $1942+$ & 2 \\
\hline & Maywood Glass & 1930-1959 & 1 \\
\hline & Hazel Atlas & 1923-1964 & 28 \\
\hline & Anchor Hocking & $1937+$ & 4 \\
\hline & Owens-Illinois & $1929+$ & 31 \\
\hline & Brockway & $1903-1983$ & 4 \\
\hline & Glass Container Co. & $?$ & 3 \\
\hline & Knox Bottle & $1932-1953$ & 7 \\
\hline & Ball & $1919-1969$ & 6 \\
\hline & Kerr & 1909 & 1 \\
\hline & Thatcher Manufacturing & $1923-1950+$ & 1 \\
\hline & Swindell & $1920-1959$ & 2 \\
\hline CERAMIC & Homer Laughlin Ovenserve & 1933-1950s & 2 \\
\hline
\end{tabular}

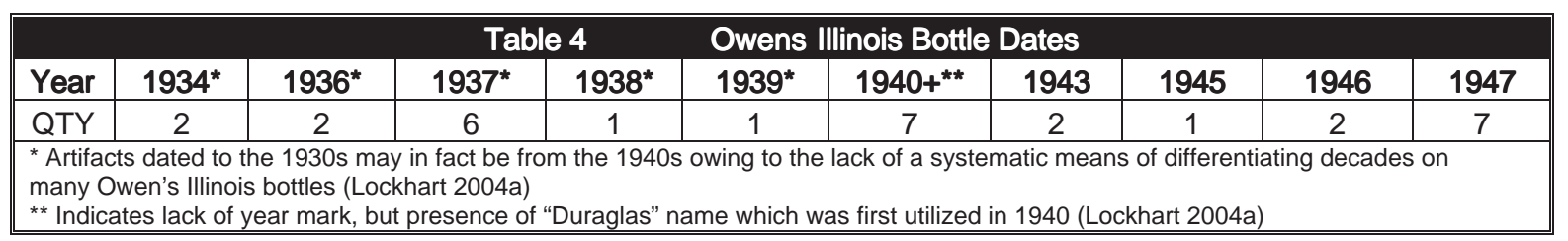


"DURAGLAS" logo on the bottle. This logo begins in 1940 and hence any bottle with the duraglas logo will date to 1940 or later. Second is the use of stippling on the bottle, a practice that again was not common until the 1940s. Based on this information, two bottles can be dated to 1943, one to 1945, two to 1946 , seven to 1947 , and an additional seven to after 1940 based on the duraglas label. The remaining 12 marked fragments could have potentially been produced in the 1930s or 1940s. Of these two are 1934/ 1944 , two are $1936 / 1946$, six are $1937 / 1947$, one is $1938 / 1948$ and one is $1939 / 1949$.

The implication of the 12 artifacts with uncertain dates is that the well may have been used for a longer or shorter time. Thus, though the bottles can serve to establish a relatively certain period of final use sometime between 1947 and 1949, they cannot be so firmly used to establish the point in time at which the well ceased functioning as a water source and was reutilized as a trash disposal feature. Nonetheless, the overall trend in the dates of the artifacts in light of the more precise dates available from the Owen's-Illinois bottles strongly reinforces the likelihood that the artifact assemblage from the well dates to the 1930s and particularly the 1940s.

\section{DISCUSSION}

The artifacts discovered during the testing of the well provide an interesting glimpse into the types of artifacts generated and disposed of on a rural farm during the 1940s and the changing role of wells at rural locations in the mid-twentieth century. The very short temporal component suggested by the deposit suggests that the trash disposal practices changed during the late 1930s or early 1940s perhaps as a consequence of the drying of the well or the extension of waste and water services to this area. A similar occurrence of the reutilization of a well in a rural setting has been described by Clark (2004: 171-180), who encountered a well associated with the Peyton Tavern that had been transformed to a site of trash disposal. Other examples of cisterns or wells reutilized as trash receptacles are fairly common in urban contexts in central Texas.

At the most general level the artifacts pertain to the sorts of activities one might associate with daily residential life, though clearly the sample is weighted towards trash generated in primarily kitchen or possibly farm related activities. Items of a more personal character such as jewelry or clothing or more typical of household furnishings are generally absent or represented by relatively low numbers of items. This pattern in the types of artifacts recovered suggests that the well was not a general trash disposal site for the house, but rather a trash disposal area for certain types of artifacts. Indeed, the prevalence of canning items and motor oil and other machinery related items does suggest that this deposit may have been associated with activities conducted in a more utilitarian residential contexts such as a barn or shop. Alternately, the types of materials recovered-metals, ceramics and glass-may have been purposefully disposed of in a manner distinct from that of food remains, which were discarded through other means, either through organized garbage collection or in some other location. The potential contamination of the water supply not withstanding, this may have been a result of the potential for harm or contamination by items of glass and metal that often contained toxic materials_-bleach, paint, turpentine - if disposed of in a more open location.

In addition to providing insight into the changing functional use of the well, the artifacts recovered also indicate certain patterns in the consumption of goods among rural households in this period and reflect the agricultural orientation of the property and presumably the inhabitants themselves. Artifacts such as the tractor seat and the milk jug attest to both an orientation towards farming as well as the raising of livestock.

Regarding patterns of consumption, there is strong evidence for the canning and pickling of fruits or vegetables by the occupants in the form of discarded Ball and Kerr jars as well as numerous vinegar bottles and spice cans. It seems likely that the products being canned or pickled were grown on the property and represented an important source of food for the inhabitants. Nonetheless, the regular recovery of sardine cans and fruit or vegetable cans indicates that the inhabitants relied a good bit on the availability of products from local groceries. That many of the condiment and vinegar bottles, as well as the bleach, coffee, and motor oil containers, are from the same company indicates either a certain degree of brand loyalty, or a relatively limited choice available from local retailers. More generally the brand uniformity exhibited by the assem- 
blage reflects a certain regularity of everyday farm life during the mid-twentieth century. Mrs. Emil Peterson Lundstedt, the daughter of Swedish immigrants, evoked this regularity in a 1978 oral interview where she described her chores involving milking the cows every morning and every night. She later talked about how her husband won her over by taking her to horse races, and out to restaurants, which she had never done before (Lundstedt 1978). For Lundstedt and other Swedes in Palm Valley, farm life was generally marked by familiarity and routine. It is this routine that the Engstrand well artifacts so aptly signifies.

One final artifact must be discussed specifically because it stands apart from the other artifacts of routine-the Minnie Mouse figurine. Made of porcelain, and intended to sit on a shelf or a table, the figurine is best described as bric-a-brac. The symbolism of bric-a-brac is often, according to Mullins (2001), multivalent and ambiguous. These "symbolically ambiguous objects allowed their parlor-making consumers to creatively day-dream about their own identities and society, not simply showcase who they were to others" (Mullins 2001). In the case of this particular object, it is not clear whether it was owned by a child or an adult. Given the universal popularity of Mickey and Minnie Mouse during the 1930s-1950s, it could have been either. Whether as child's toy or adult's trinket, Mickey and Minnie Mouse are complex and mythic characters that encode many layers of cultural meaning. Disney characters, particularly Mickey, Minnie and Pluto, are wholesome in the extreme and over the years have become interchangeable symbols not just of American ideals, but also American consumer culture.

Mickey and Minnie Mouse became household names during the Great Depression and WWII years through short animated films that ran in movie theaters before the headlining film. Though Mickey made his screen debut in 1928, Minnie did not appear until 1929. In 1930, a dog was added who was later named Pluto, after the newly discovered ninth planet (http://disney.go.com/vault/archives/ characters_jq.html 2007). Mickey and Minnie's early films were initially modeled on slapstick comedy routines, while later 1930s and 40s pieces incorporated more charm and sentiment (Brockway 1989). By the 1940s Walt Disney's cartoon characters were among the most well-known popular culture icons, and formed the foundation for Walt Disney's considerable entertainment empire. Mickey Mouse was listed in Who's Who as early as 1933, and in the same year Encyclopedia Britannica even devoted an entire entry to him. Mickey and Minnie Mouse figurines and watches were sold as early as 1931 (Brockway 1989).

The figurine from the well depicts Minnie Mouse, seated next to someone who is presumably Mickey, who has his arm around her. The Mickey portion of the figurine, however, has broken off. At their feet sits Pluto. From the sharpness of Minnie's nose and relatively small size of her ears it is evident that the figurine probably pre-dates the 1940s. As Stephen Jay Gould pointed out (1979) Mickey began his career looking very rat-like. This rat-like appearance harmonized with his somewhat ambiguous identity as a trickster or joker. As he progressively became a national hero, his features grew shorter, rounder, and fatter-in essence he became cuter (Lawrence 1986). So too did his character change; Mickey became more childlike and innocent. The Minnie (and presumably Mickey) of the figurine in the well still retains the thin arms, sharp nose and smallish ears of the earliest character iterations. In the evolution of the Mickey and Minnie characters, the figurines correspond to a time when the duo were still doing slapstick, but had already become national symbols of hope and innocent fun.

The figurine is curious not only because of its periodicity but also because of its symbolism within the context of the larger artifact assemblage. It is one of the few very personal items found within an assemblage largely dominated by impersonal household activity items such as canning jars, tools, tractor parts, and condiment bottles, which were likely set aside in a barn or shed before ultimately being dumped in a well. What then does this say about the significance of the Minnie Mouse figurine, which must also have been set aside from the displayed household bric-a-brac (perhaps because it was broken, or perhaps because its owner outgrew it), but not immediately discarded? Given the broadbased, popular appeal of Mickey and Minnie Mouse during this period, it seems reasonable to speculate that the figurine had sentimental value for its owner. Though precise relationships are impossible to determine, it is nonetheless plausible to situate this figurine within Mullin's framework of "creative daydreaming." In this case, the daydreams are 
spawned through film characters that symbolize irrepressible optimism, fun, heroism and a little bit of mischief. The figurine is also firmly rooted in Depression and WWII generation American ideals, which consciously privileged optimism, determination, and innocence. Disney himself stated that Mickey Mouse appealed to that "absolutely primitive remnant of something in every world-wracked human being which makes us play with children's toys and laugh without self-consciousness at silly things, and sing in the bathtub and dream..." (quoted from Lawrence 1986). Though Mickey and Minnie have survived as popular culture symbols into the present time, their appeal resonates much more strongly among the Depression era generation (Brockway 1989). In this context, it seems entirely fitting that Mickey, Minnie and Pluto should turn up in a largely utilitarian farm assemblage. Like the characters it represents, the figurine may have provided a little color, a little excitement, and perhaps even a little mischief to a life otherwise marked by routine and predictability. 


\section{Chapter 6}

\section{Conclusions and Recommendations}

The property containing the well, Site 41WM1157, was first improved during the 1870s when it was purchased by Carl Engstrand, a Swedish immigrant and prominent member of the Palm Valley community. The well was probably built by Engstrand to irrigate fields and provide water for residences. It is not certain whether Engstrand and his family lived on the property during the 1870s. However, it is possible he lived there for a short time before building a house in downtown Round Rock in 1889 and around 1910. The well is almost certainly associated with a standing structure located approximately 60 meters to the north (Figure
24), though the construction date of that structure has not been determined. The extended Engstrand family owned the land until 1996. Though several tenants are known to have occupied the associated house north of the well, Engstrand's daughter and granddaughter also occupied the house at various times during the twentieth century.

Site 41WM1157 is a hand-dug limestone well probably constructed in the 1870 s. It is associated with significant local personages in the Palm Valley community, the Engstrand family. The well is filled with mid-twentieth century household and farm debris from the 1940s and appears to have

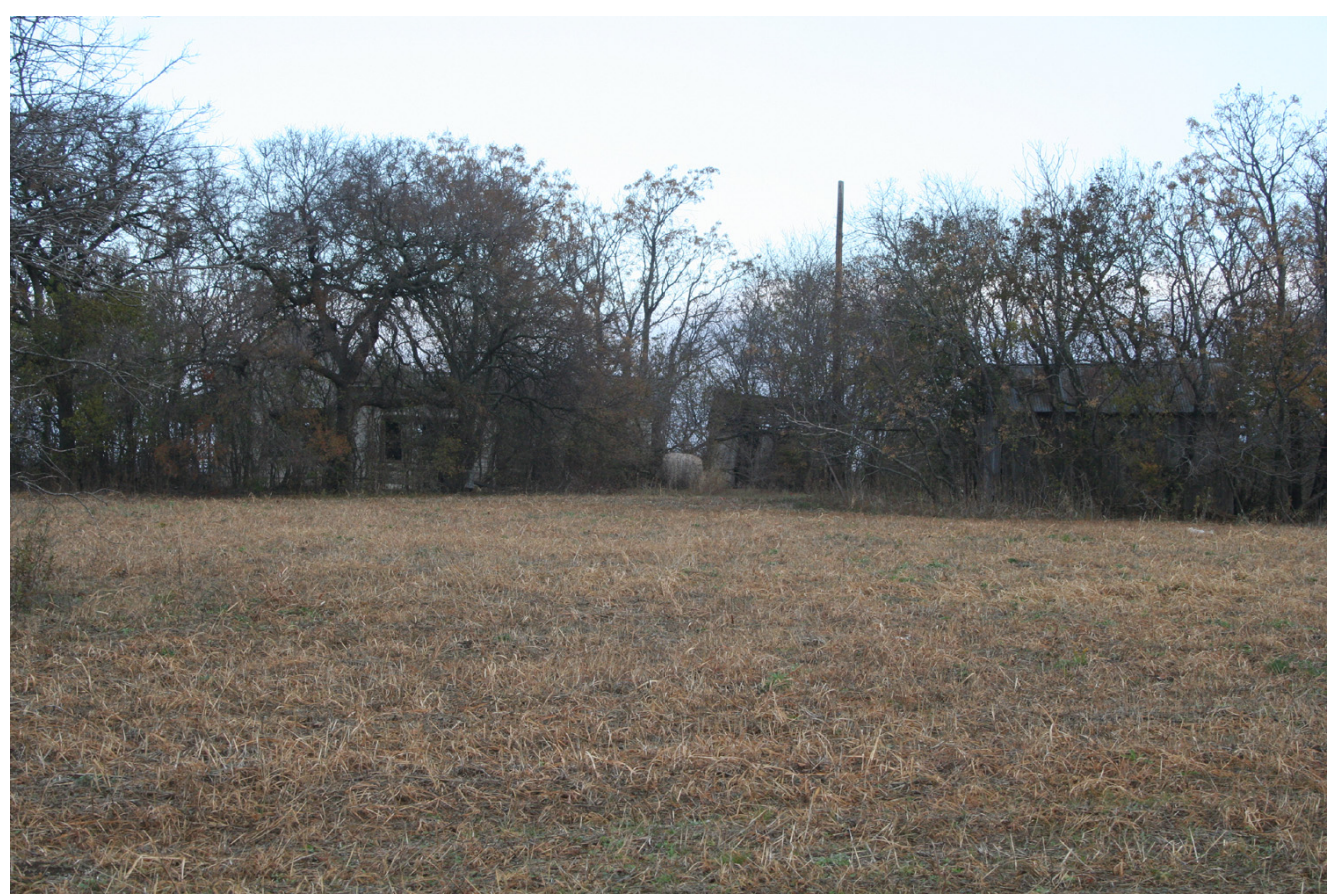

Figure 24. House and associated structures north of 41WM1157. 
been filled in a single episode of trash disposal. In general the artifacts from within the well reflect the routine of farm life among the Swedish community of Palm Valley. One notable artifact, however, a broken Mickey and Minnie Mouse figurine, offers an opportunity to speculate about the ideals and possibly day dreams of the inhabitants.

Despite the larger property's association with a prominent local family, the well alone is not significant in that it is of typical construction, and it is filled entirely with artifacts that date to the mid-twentieth century. The larger associated property and the associated standing nineteenth century house have not been assessed for National Register eligibility under any criteria. However, the well, as an ancillary structure, does not contain sufficient integrity, context, or architectural merit to allow it to be considered eligible for the National Register of Historic Places. The well and artifacts also do not contribute to the NRHP eligibility of the larger associated property and standing nineteenth century house. It is not recommended as eligible for the National Register of Historic Places, under Criteria B or C. While it is possible that the artifacts within the well are associated with members of the Engstrand extended family, it is equally likely that the artifacts represent the debris accumulation of unnamed tenants. Given their late date, the uniformity of the assemblage, absence of context, and the lack of any clear linkage to the Engstrand family, the artifacts do not contribute to the site's eligibility for the National Register of Historic Places, under Criteria A or D. During excavations, investigators recovered approximately one-third of the well fill, a statistically valid sample, which was then cataloged and analyzed. The well was effectively destroyed during the process of excavation and documentation. Thus, not only was further archeological fieldwork deemed unnecessary, but also impracticable. It is the opinion of the Principal Investigator that the portion of Site 41WM1157 located within the US 79 right-of-way does not contribute to the site's eligibility for listing in the National Register of Historic Places and does not warrant designation as a State Archeological Landmark. The Principal Investigator recommended that no further archeological field investigations or historical research was warranted for Site 41WM1157 in an interim report dated December 21, 2007. TxDOT coordinated the report with the State Historic Preservation Officer through a letter dated January 18, 2007, and concurred with the recommendation. Further analysis for this report was undertaken in April and May of 2007. This report is offered in partial fulfillment of TAC Permit \#4347. A sample of the artifacts and all project notes, records and photographs will be curated at TARL 


\section{Bibliography}

Anonymous

2007 "Swedish Histowall." Typed Manuscript filed under Swedes in Texas, on file at the Austin History Center, Austin.

Anthony, Dana

1996 Cisterns and Wells at the Austin Convention Center. Unpublished manuscript stored at Hicks \& Company, Austin.

Behrens, Jan and Howard Widmer

1995 Palm Valley Lutheran Church, Round Rock, Texas 1870-1995. Palm Valley Lutheran Church, Round Rock.

Blair, W. Frank

1950 The Biotic Provinces of Texas. Texas Journal of Science 2(1): 93-117.

Brockway, Robert

1989 The Masks of Mickey Mouse: Symbol of a Generation. Journal of Popular Culture, 22:4. pp. 25-34.

Clark, John

2004 Under Four Flags: History and Archeology of North Loop One, Travis County, Texas. Archeological Studies Program, Report 57. Texas Department of Transportation, Environmental Affairs Division, Austin.

Feit, Rachel, and John Clark

2002 Archeological Investigations on the Historic Hannig-Dickinson House and the Hedgecoxe House in Austin, Texas. Archeology Series 109. Hicks \& Company, Austin.

Gould, F. W.

1975 Texas Plants: A Checklist and Ecological Summary. The Texas A\&M University System, Texas Agricultural Experiment Station, College Station.

Gould, Stephen Jay

1979 This View of Life: Mickey Mouse Meets Konrad Lorenz. Natural History, 88:5. pp.30-36.
Griffith, Timothy and Rachel Feit

2000 A Cultural Resources Assessment for the Proposed Alignment for the New Wastewater Pipeline Along Chandler Creek. Archeology Series 78. Hicks \& Company, Austin.

Lawrence, Elizabeth

1986 In the Mick of Time: Reflections on Disney's Ageless Mouse. Journal of Popular Culture 20:2. pp.65-72.

Leffler, John

1996 Palm Valley Texas. In The Handbook of Texas. Edited by Ron Tyler, Vol. 5. The Texas Historical Association, Austin.

Lehner, Lois

1988 Lehner's Encyclopedia of U.S. Marks on Pottery, Porcelain and Clay. Collector Books. Paducah, Kentucky.

Lockhart, Bill

2004a The Dating Game. Electronic document, http:// www.blm.gov/historic_bottles/pdffiles/OwensIll _BLockhart.pdf, accessed December 18, 2006.

2004b Knox Glass and the Marks Toulouse Missed. Electronic Document, http://www.blm.gov/historic bottles/pdffiles/OwensIll_BLockhart.pdf, accessed December 18, 2006.

Lundstedt, Mrs. Emil Peterson

1978 Interview with Mrs. Emil Peterson Lundstedt. Conducted by Shirley Prud'homme. Typed transcript on file at the Austin History Center, Austin

Moore, Richard

1996 Swenson, Swante Magnus. In The New Handbook of Texas. Edited by Ron Tyler, Vol. 6. The Texas Historical Association, Austin.

Mullins, Paul

2001 Racializing the Parlour: Race and Victorian Bric-aBrac Consumption. In Race and the Archaeology of Identity, ed. by Charles Orser. Foundations of Archaeological Inquiry Series. University of Utah Press, Salt Lake City. 
South, Stanley

1977 Method and Theory in Historical Archaeology. Academic Press, New York.

Swedish Pioneer Historical Quarterly

1965 Swedish Pioneer Mutual Aid Societies in Texas. Swedish Pioneer Historical Quarterly Vol. XVI:2. pp.100-104.

Texas Writers Project

193[u] Austin File Chronological. Volumes 1900 and 1915. Unpublished manuscript on file at the Austin History Center, Austin.

Toulouse, Julian Harrison

1971 Bottlemakers and Their Marks. Thomas Nelson, New York.
United States Census Records

1870, 1880, 1900, 1910, 1920, 1930

Williamson County Deed Records and Indexes (WCDR)

1871-1925 Various Volumes on File at the Williamson County Clerks Office, Georgetown, Texas

Wright, G. Kenneth

1997 Archaeology at the Alamodome: Investigations of a San Antonio Neighborhood in Transition. Volume II. Series edited by Anne Foxe, Marcie Renner and Robert J, Hard. Archaeological Survey Report 237. Center for Archaeological Research, San Antonio. 
Appendix A

Specimen Inventory 



\begin{tabular}{|c|c|c|c|c|c|c|c|c|c|c|}
\hline Lot\# & \begin{tabular}{|l} 
Unique \\
Item \#
\end{tabular} & Item Description & Material type & \begin{tabular}{|l} 
Functional \\
Category
\end{tabular} & QTY & WT (G) & Provenience & Maker's Mark - maker & Date of mark & Notes \\
\hline 1 & D & Metal can fragments & Metal & Kitchen & 6 & 26 & Bag 1, odd surface finds around well before excavation & & & \begin{tabular}{|l}
$\begin{array}{l}\text { Rusted, one almost completer lid } \\
\text { with concentric circles }\end{array}$ \\
\end{tabular} \\
\hline 1 & D & $\begin{array}{l}\text { Glass - Misc. Clear bottle } \\
\text { fragments }\end{array}$ & Glass & Kitchen & ${ }^{2}$ & 4 & Bag 1, odd surface finds around well before excavation & & & \\
\hline 2 & D & \begin{tabular}{|l} 
Metal external threaded \\
bottle/jar lid fragments
\end{tabular} & Metal & kitchen & 3 & 5 & Bag 2, about 40 cmbs from interior of well & & & \\
\hline$\frac{2}{2}$ & $D$ & Metal can fragments & Metal & Kitchen & $\frac{1}{2}$ & 2 & Bag 2, about $40 \mathrm{cmbs}$ from interior of well & & & \\
\hline 2 & D & $\begin{array}{l}\text { Misc. Clear glass bottle } \\
\text { fragments }\end{array}$ & Glass & Kitchen & 2 & 24 & Bag 2, about $40 \mathrm{cmbs}$ from interior of well & & & \begin{tabular}{|l} 
one with neck fragment with \\
external threading
\end{tabular} \\
\hline 3 & $3-1$ & Tin can lid & Metal & Kitchen & 1 & 41 & Bag 3, surface to pre-excavation level, clean up & $\begin{array}{l}\text { Folgers Coffee } \\
\end{array}$ & & "...LGERS"; pry off lid, $13 \mathrm{~cm}$ \\
\hline 3 & 3 & Bottle or drinking glass & Glass & Kitchen & 1 & 8 & Bag 3, surface to pre-excavation level, clean up & & & \begin{tabular}{|l|} 
clear bottle or drinking glass with \\
repeatitig silk screen pattern, red \\
dot with 3 concentric circles
\end{tabular} \\
\hline 3 & D & $\begin{array}{l}\text { Unidentified metal can } \\
\text { fragments }\end{array}$ & Metal & Kitchen & 2 & 110 & Bag 3, surface to pre-excavation level, clean up & & & \\
\hline 3 & D & \begin{tabular}{|l|l|} 
Metal wire \\
\end{tabular} & Metal & \begin{tabular}{|l|l|l} 
Unknown \\
\end{tabular} & 1 & 2 & Bag 3, surface to pre-excavation level, clean up & & & \\
\hline 3 & D & Light bulb glass fragments & Glass & \begin{tabular}{|l}
$\begin{array}{l}\text { Household/ } \\
\text { Furniture }\end{array}$ \\
\end{tabular} & 5 & 5 & Bag 3, surface to pre-excavation level, clean up & & & \\
\hline$\frac{3}{3}$ & $\frac{D}{D}$ & Brown paper & plant & \begin{tabular}{|l|l|l|l|l|l} 
Unknown \\
Architecture
\end{tabular} & $\frac{1}{1}$ & $\frac{19}{5}$ & 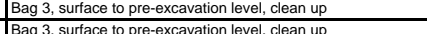 & & & \\
\hline$\frac{5}{3}$ & D & Tin foil & 荝etal & $\begin{array}{l}\text { Kintithen } \\
\end{array}$ & $\frac{2}{2}$ & $<1$ & 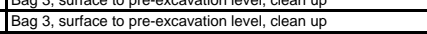 & & & \\
\hline 3 & D & $\begin{array}{l}\begin{array}{l}\text { White plastic or aluminum } \\
\text { threaded bottle cap }\end{array} \\
\text { S }\end{array}$ & Metal & \begin{tabular}{|l|l|} 
Kitchen \\
\end{tabular} & 1 & $4^{4}$ & \begin{tabular}{|l} 
Bag 3, surface to pre-excavation level, diean up \\
\end{tabular} & & & \\
\hline 3 & D & White Ware plate fragment & Ceramic & Kitchen & 1 & 4 & Bag 3, surface to pre-excavation level, clean up & & & \\
\hline 3 & D & Misc. clear bottle glass & Glass & Kitchen & 14 & 65 & Bag 3, surface to pre-excavation level, clean up & & & \\
\hline 3 & D & Clear bottle base & Glass & Kitchen & 1 & 46 & Bag 3, surface to pre-excavation level, clean up & 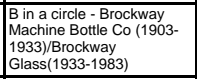 & 1925 & B in a circle "M-5", clear, round \\
\hline 3 & $\mathrm{D}$ & Clear bottle base & Glass & Kitchen & 1 & 36 & Bag 3, surface to pre-excavation level, clean up & $\begin{array}{l}\text { Hover A- Hazel Atlas } \\
(1902-1964)\end{array}$ & 1923-1964 & $\mathrm{H}$ with $\mathrm{A}$ inside \\
\hline 4 & D & Clear bottle glass & Glass & Kitchen & 26 & 126 & $\begin{array}{l}\text { Bag } 4 \text {, from surface of well to pre-excavation surface- south } \\
\text { bisect }\end{array}$ & \begin{tabular}{|l} 
Duraglas (1940+) - Owens- \\
Ilinois (1929-present)
\end{tabular} & $1940+$ & $\begin{array}{l}\text { Duraglas is an Owens-llinois } \\
\text { trademark ca. } 1940\end{array}$ \\
\hline 4 & D & Brown bottle glass & Glass & Kitchen & 1 & 8 & $\begin{array}{l}\text { Bag } 4 \text {, from surface of well to pre-excavation surface- south } \\
\text { biset }\end{array}$ & & & \\
\hline 4 & 4-1 & Decorative glass & Glass & \begin{tabular}{|l|l}
$\begin{array}{l}\text { Household / } \\
\text { Funniture }\end{array}$ \\
\end{tabular} & ${ }^{2}$ & 21 & $\begin{array}{l}\text { Bag } 4 \text { from surface of well to pre-excavation surface-south } \\
\text { bisect }\end{array}$ & & & $\begin{array}{l}\text { embossed circles, possibly etched, } \\
\text { possibly faint blue, unknown } \\
\text { function }\end{array}$ \\
\hline 4 & 4-2 & Tin can lid & Metal & Kitchen & 1 & 7 & $\begin{array}{l}\text { Bag } 4 \text {, from surface of well to pre-excavation surface- south } \\
\text { bisef }\end{array}$ & Cin a triangle & & \\
\hline 4 & $4-3$ & motor oil cans & Metal & Transportation & 1 & 108 & $\begin{array}{l}\text { Bag } 4 \text {, from surface of well to pre-excavation surface- south } \\
\text { bisect }\end{array}$ & Gulf motor oil & & 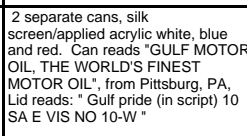 \\
\hline 4 & $4-4$ & Jar with lid & Composite & Kitchen & 1 & 253 & $\begin{array}{l}\text { Bag } 4 \text {, from surface of well to pre-excavation surface- south } \\
\text { bisect }\end{array}$ & 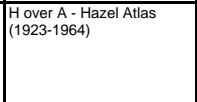 & 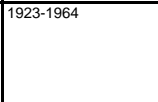 & 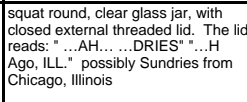 \\
\hline 4 & $4 \cdot 5$ & Ink bottle & Glass & Education & 1 & 107 & $\begin{array}{l}\text { Bag } 4 \text {, from surface of well to pre-excavation surface- south } \\
\text { bisect }\end{array}$ & Sheaffer Skrip Ink & 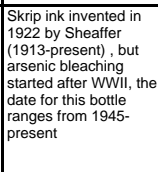 & 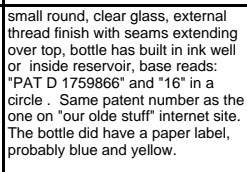 \\
\hline 4 & $4 \cdot 6$ & Divco Solder & Metal & Activities & 1 & 23 & $\begin{array}{l}\begin{array}{l}\text { Bag } 4 \text {, from surface of well to pre-excavation surface- south } \\
\text { bisect }\end{array} \\
\end{array}$ & & & $\begin{array}{l}6 \mathrm{~cm} \text { diameter, } 2.3 \mathrm{~cm} \text { tall, round } \\
\text { flux container with pry-off lil, red } \\
\text { and yellow painted } / \text { silk screen label }\end{array}$ \\
\hline 4 & D & Molded edge glass frag & Glass & $\begin{array}{l}\text { Household/ } \\
\text { Funniture }\end{array}$ & 1 & 19 & $\begin{array}{l}\begin{array}{l}\text { Bag } 4 \text {, from surface of well to pre-excavation surface- south } \\
\text { bisect }\end{array} \\
\end{array}$ & & & $\begin{array}{l}\text { Clear glass, possibly lamp shade } \\
\text { glass }\end{array}$ \\
\hline 4 & D & \begin{tabular}{|l|l|l} 
Light bulb glass fragments \\
\end{tabular} & Glass & $\begin{array}{l}\text { Household// } \\
\text { Funniture }\end{array}$ & 5 & 2 & $\begin{array}{l}\text { Bag } 4 \text {, from surface of well to pre-excavation surface- south } \\
\text { bisect }\end{array}$ & "GE" & & "40W 120V \\
\hline 4 & D & White ware, & Ceramic & Kitchen & 2 & 24 & $\begin{array}{l}\text { Bag } 4 \text {, from surface of well to pre-excavation surface- south } \\
\text { bisect }\end{array}$ & & & one cup frag, one plate frag \\
\hline 4 & D & White paper & plant & Unknown & 1 & 1 & $\begin{array}{l}\text { Bag } 4 \text {, from surface of well to pre-excavation surface- south } \\
\text { bisect }\end{array}$ & & & \\
\hline 4 & $\mathrm{D}$ & light bulb bases & Glass & $\begin{array}{l}\text { Household/ } \\
\text { Funniture }\end{array}$ & 2 & 22 & $\begin{array}{l}\begin{array}{l}\text { aag } 4 \text {, from surface of well to pre-excavation surface- south } \\
\text { biset }\end{array} \\
\text { a }\end{array}$ & & & $\begin{array}{l}\text { composite of metal, glass, plastic, } 2 \\
\text { separate light bulss }\end{array}$ \\
\hline 4 & D & Metal fragments & Metal & Kitchen & & 408 & $\begin{array}{l}\text { Bag } 4 \text {, from surface of well to pre-excavation surface- south } \\
\text { biset }\end{array}$ & & & \\
\hline 4 & $\mathrm{D}$ & Metal wire & Metal & Tool & 2 & 61 & $\begin{array}{l}\text { Bag } 4 \text {, from surface of well to pre-excavation surface- south } \\
\text { bisect }\end{array}$ & & & \\
\hline 4 & D & Rusted scrap metal & Metal & kitchen / misc. & 1 & 44 & $\begin{array}{l}\text { Bag } 4 \text {, from surface of well to pre-excavation surface- south } \\
\text { biset }\end{array}$ & & & possibly spelter \\
\hline 5 & 5 & complete clear bottle & Glass & Kitchen & 1 & 267 & Bag 5, Level 2, 83-103 cmbs & \begin{tabular}{|l} 
Duraglas (1940+)- Owens- \\
lilinois (1929-present)
\end{tabular} & $1940+$ & $\begin{array}{l}\text { clear glass, ext thread, top half has } \\
\text { 16 fiat sided design. Base has } \\
\text { diamond-oval- with Duraglas in } \\
\text { script and "1735" }\end{array}$ \\
\hline 5 & $5-2$ & Decorative glass & Glass & \begin{tabular}{|l} 
Household \\
Funniture
\end{tabular} & 1 & 25 & Bag 5, Level 2, 83-103 cmbs & & & possibly matching lot 4-1 \\
\hline 5 & $5 \cdot 3$ & Whiteware plate fragment & Ceramic & Kitchen & 1 & 20 & Bag 5, Level 2, 83-103 cmbs & $\begin{array}{l}\text { "....RVE" - portion of Homer } \\
\text { Laughhlin OvenServe }\end{array}$ & 1933-1950's & \begin{tabular}{|l}
$\begin{array}{l}\text { printed partial makers, refit with frag } \\
\text { from bag } 8\end{array}$ \\
\end{tabular} \\
\hline 5 & $5-4$ & \begin{tabular}{|l}
$\begin{array}{l}\text { Base of square whiteware } \\
\text { container }\end{array}$ \\
\end{tabular} & Ceramic & Kitchen & 1 & 30 & Bag 5, Level 2, 83-103 cmbs & Unknown & & \\
\hline 5 & D & \begin{tabular}{|l} 
Unidentified metal can \\
fragments
\end{tabular} & Metal & Kitchen & & 4309 & Bag 5, Level 2, 83-103 cmbs & & & \\
\hline 5 & D & \begin{tabular}{|l|} 
Aluminum bucket \\
\end{tabular} & Metal & Tools & 1 & 133 & Bag 5, Level 2, 83-103 cmbs & & & \\
\hline 5 & D & $\begin{array}{l}\text { Small spelter bucket with } \\
\text { corroded }\end{array}$ & Metal & Tools & 1 & 217 & Bag 5, Level 2, 83-103 cmbs & & & \\
\hline$\frac{5}{5}$ & D & \begin{tabular}{|l} 
One large spelter bucket \\
\end{tabular} & 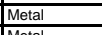 & Tools & 1 & 2041 & Bag 5, Level 2, 83-103 cmbs & & & some dirt included in weight \\
\hline 5 & D & Motor oil can & Metal & Transportation & 1 & 82 & Bag 5, Level 2, 83-103 cmbs & Gulf motor oil & & opened with church key \\
\hline 5 & D & Folger's Coffee Can & Metal & Kitchen & 1 & 135 & Bag 5, Level 2, 83-103 cmbs & $\begin{array}{l}\text { J.A. Folger \& co, San } \\
\text { Francisco, CA since 1872, } \\
\text { in } 1946 \text { the elters are all } \\
\text { caps, by } 1956 \text { only the } F \text { is } \\
\text { in capital letters. }\end{array}$ & & \\
\hline 5 & $\mathrm{D}$ & Tobacco lid? & Metal & Tobacco & 1 & 6 & Bag 5, Level 2, 83-103 cmbs & & & rectangular tin lid -pry off \\
\hline 5 & D & \begin{tabular}{|l|l|l|l} 
Plastic or aluminum bottle caps \\
\end{tabular} & Metal & Kitchen & 3 & 15 & Bag 5, Level 2, 83-103 cmbs & & & \\
\hline
\end{tabular}




\begin{tabular}{|c|c|c|c|c|c|c|c|c|c|c|}
\hline Lot\# & $\begin{array}{l}\text { Unique } \\
\text { tiem }\end{array}$ & Item Description & Material type & \begin{tabular}{|l|} 
Functional \\
Catagory
\end{tabular} & $\overline{\text { QTY }}$ & WT (G) & Provenience & Maker's Mark - maker & Date of mark & Notes \\
\hline 5 & D & Round pry-off cap & Metal & Kitchen & 1 & 7 & Bag 5, Level 2, 83-103 cmbs & & & hot cocoa? Or baking soda? \\
\hline 5 & $\mathrm{D}$ & Washer & Metal & Tool & 1 & 6 & Bag 5, Level 2, 83-103 cmbs & & & \\
\hline 5 & D & $\begin{array}{l}\text { Pulled wire nails } \\
\end{array}$ & Metal & Architecture & 3 & 17 & Bag 5, Level 2, 83-103 cmbs & & & \\
\hline 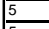 & D & Piece of wire fencing & Metal & Architecture & 1 & 6 & Bag 5, Level 2, 83-103 cmbs & & & \\
\hline 5 & D & Metal bar fragments & Metal & $\begin{array}{l}\mid \begin{array}{l}\text { Unknown / } \\
\text { misc. }\end{array} \\
\end{array}$ & 1 & 9 & Bag 5, Level 2, 83-103 cmbs & & & \\
\hline 5 & D & \begin{tabular}{|l|l|l|l|l|l|} 
Metal \\
\end{tabular} & \begin{tabular}{|l|l|} 
Metal \\
\end{tabular} & \begin{tabular}{|l|l|l|l} 
Kitchen \\
Ton
\end{tabular} & 1 & 54 & Bag 5, Level 2, 83-103 cmbs & & & cap to engine fluids? \\
\hline 5 & $\mathrm{D}$ & Spark plug & Composite & Transportation & 1 & 63 & Bag 5, Level 2, 83-103 cmbs & & & metal and porcelain \\
\hline 5 & D & Light bulb base fragment & Composite & \begin{tabular}{|l|} 
Household / \\
Funniture
\end{tabular} & 1 & 15 & \begin{tabular}{|l|} 
Bag 5, Level 2, 83-103 cmbs \\
\end{tabular} & & & \\
\hline 5 & $\mathrm{D}$ & $\begin{array}{l}\text { Jar fragments with metal lids } \\
\text { still atached }\end{array}$ & Composite & \begin{tabular}{|l|l|l|l|l} 
Kitchen \\
\end{tabular} & 3 & 138 & Bag 5, Level 2, 83-103 cmbs & & & clear glass and threaded metal lids \\
\hline 5 & D & Milk glass jar frag with lid & Composite & Grooming & 3 & 34 & Bag 5, Level 2, 83-103 cmbs & & & threaded metal lid \\
\hline 5 & $\mathrm{D}$ & Black plastic lid & Synthetic & Kitchen & 1 & 6 & Bag 5, Level 2, 83-103 cmbs & & & \\
\hline 5 & $\mathrm{D}$ & \begin{tabular}{|l|} 
Black plastic lid \\
\end{tabular} & Synthetic & Kitchen & 1 & 1 & Bag 5, Level 2, 83-103 cmbs & & & \\
\hline 5 & $\mathrm{D}$ & \begin{tabular}{|l|} 
Black rubber \\
\end{tabular} & Synthetic & $\begin{array}{ll}\text { Unknown } \\
\end{array}$ & 3 & 13 & Bag 5, Level 2, 83-103 cmbs & & & hose? "PATENT" on bottom \\
\hline$\frac{5}{5}$ & $\frac{D}{D}$ & \begin{tabular}{|l|} 
Adult shoe heel \\
Complete ketchup bottle
\end{tabular} & \begin{tabular}{|l|} 
Synthetic \\
Glass \\
\end{tabular} & \begin{tabular}{|l|} 
Clothing \\
Kitchen \\
\end{tabular} & $\frac{1}{1}$ & $\frac{55}{298}$ & \begin{tabular}{|l|} 
Bag 5, Level 2, 83-103 cmbs \\
Bag 5, Level 2, 83-103 cmbs
\end{tabular} & & & clear glass, bottom half of bottle has \\
\hline & $D^{D}$ & Complete ketchup bottle & & Kitchen & & 298 & Bag 5, Level 2, 83-103 cmbs & 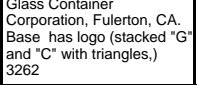 & & $\begin{array}{l}\text { lelear glass, bottom half of bottle has } \\
\text { 8smoothed edges, used to have a } \\
\text { paper label }\end{array}$ \\
\hline 5 & $\mathrm{D}$ & Complete clear glass jar & 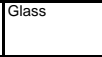 & Kitchen & & 302 & Bag 5, Level 2, 83-103 cmbs & $\begin{array}{l}\text { Hover A-Hazel Atlas } \\
(1923-1964)\end{array}$ & 1923-1964 & $\begin{array}{l}\text { 5104 on base; squat, round, with } \\
\text { stippping ext. threading, seams over } \\
\text { top of lip. }\end{array}$ \\
\hline 5 & $\mathrm{D}$ & Complete clear bottle - Vinegar & Glass & Kitchen & & 278 & Bag 5, Level 2, 83-103 cmbs & $\begin{array}{l}\begin{array}{l}\text { Hover A-Hazel Atlas } \\
(1923-1964)\end{array} \\
\end{array}$ & 1923-1964 & 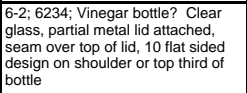 \\
\hline 5 & $\mathrm{D}$ & misc. bottle body fragments & Glass & Kitchen & $\overline{143}$ & 1193 & Bag 5, Level 2, 83-103 cmbs & & & \begin{tabular}{|l|} 
clear glass \\
\end{tabular} \\
\hline 5 & $\mathrm{D}$ & External threaded jar frags & $\begin{array}{l}\text { Glass } \\
\end{array}$ & Kitchen & 10 & 109 & Bag 5, Level 2, 83-103 cmbs & & & clear glass, side seams over top \\
\hline 5 & $\mathrm{D}$ & \begin{tabular}{|l|l|} 
External threaded bottle frags \\
\end{tabular} & $\begin{array}{l}\text { Glass } \\
\end{array}$ & Kitchen & 5 & 112 & Bag 5, Level 2, 83-103 cmbs & & & \\
\hline 5 & $\mathrm{D}$ & Silk Screened Glass & Glass & Kitchen & 6 & 34 & Bag 5, Level 2, 83-103 cmbs & & & Clear glass with ACL \\
\hline 5 & $\mathrm{D}$ & Base frag & Glass & Kitchen & 1 & 8 & Bag 5, Level 2, 83-103 cmbs & "sterling" in script & Unknown & clear glass, round jar, \\
\hline 5 & D & Base frag & Glass & Kitchen & 1 & 15 & Bag 5, Level 2, 83-103 cmbs & \begin{tabular}{|l|} 
Duraglas (1940+) - Owens- \\
Ilinois (1929-present)
\end{tabular} & $1940+$ & clear round jar \\
\hline 5 & $\mathrm{D}$ & \begin{tabular}{|l} 
Drinking glass \\
\end{tabular} & & Kitchen & 6 & 34 & & & & $\begin{array}{l}\text { mixed fragments of drinking glasses } \\
\text { with silk screened paterns such as } \\
\text { red and white striped, blue striped, } \\
\text { and white flowers }\end{array}$ \\
\hline 5 & D & Clear jar base frag & $\begin{array}{l}\text { Glass } \\
\end{array}$ & Kitchen & 1 & 29 & Bag 5, Level 2, 83-103 cmbs & $\begin{array}{l}\text { In a keystone- Knox } \\
\text { Bottle C.. (1932-1953). } \\
\text { Jacksonville, MS plant }\end{array}$ & 1932-1953 & also 4416 on base \\
\hline 5 & D & Clear jar base frag & Glass & Kitchen & 1 & 41 & Bag 5, Level 2, 83-103 cmbs & $\begin{array}{l}\text { Hover A- Hazel Atlas } \\
(1923-1964)\end{array}$ & 1923-1964 & $\begin{array}{l}\text { round shape, "6-1 above and } \\
\text { K4364" below }\end{array}$ \\
\hline 5 & $\mathrm{D}$ & Clear jar base frag & 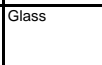 & Kitchen & 1 & 76 & Bag 5, Level 2, 83-103 cmbs & $\begin{array}{l}\text { Owens-lllinois (1929- } \\
\text { present) }\end{array}$ & 1933 or 1943 & 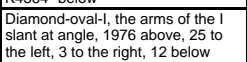 \\
\hline 5 & $\mathrm{D}$ & Clear jar base frag & Glass & Kitchen & 1 & 57 & Bag 5, Level 2, 83-103 cmbs & Unknown & & "F1976" on base \\
\hline 5 & D & Clear jar base frag & Glass & Kitchen & 1 & 37 & Bag 5, Level 2, 83-103 cmbs & \begin{tabular}{|l} 
Anchor Hooking (1937- \\
present)
\end{tabular} & $1937+$ & $\begin{array}{l}3512 \text { above, } 3 \text { to the right, } 10 \\
\text { below, llake variant } 2 \text { (oval-ish) } \\
\text { base shape }\end{array}$ \\
\hline 5 & D & Clear glass base & Glass & Kitchen & 1 & 96 & Bag 5, Level 2, 83-103 cmbs & $\begin{array}{l}\text { Anchor Hocking (1937- } \\
\text { present) }\end{array}$ & $1937+$ & \\
\hline 5 & D & Clear base fragment & Glass & Kitchen & 1 & 126 & Bag 5, Level 2, 83-103 cmbs & $\begin{array}{l}\text { Unknown (Hazel Atlas?) } \\
\end{array}$ & 1923-1964? & 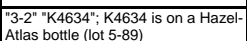 \\
\hline 5 & D & \begin{tabular}{|l} 
Light bulb glass fragments \\
\end{tabular} & Glass & \begin{tabular}{|l|} 
Household / \\
Euritions
\end{tabular} & 9 & 8 & Bag 5, Level 2, 83-103 cmbs & & & \\
\hline 5 & D & Window pane glass & Glass & $\begin{array}{l}\text { Aurnture } \\
\text { Architecture }\end{array}$ & 5 & 32 & Bag 5, Level 2, 83-103 cmbs & & & \\
\hline 5 & D & Kelly Green base frag & Glass & Kitchen & 1 & 19 & Bag 5, Level 2, 83-103 cmbs & & $1940+$ & stippling present \\
\hline 5 & D & \begin{tabular}{|l} 
Blue transparent concave- \\
shaped glass
\end{tabular} & Glass & $\begin{array}{l}\begin{array}{l}\text { Household } / \\
\text { Funniture }\end{array} \\
\end{array}$ & 1 & 1 & Bag 5, Level 2, 83-103 cmbs & & & possibly light bulb glass \\
\hline 5 & $\mathrm{D}$ & \begin{tabular}{|l|l|} 
Black rubber \\
\end{tabular} & Synthetic & \begin{tabular}{|l|l|l} 
Unknown \\
\end{tabular} & 1 & 4 & Bag 5, Level 2, 83-103 cmbs & & & \\
\hline 5 & $\mathrm{D}$ & Brown Glass fragments & Glass & Kitchen & 12 & 105 & Bag 5, Level 2, 83-103 cmbs & & & \\
\hline 5 & $\mathrm{D}$ & Hi-lex Bleach bottle fragments & $\begin{array}{l}\text { Glass } \\
\end{array}$ & Activities & 5 & 74 & Bag 5, Level 2, 83-103 cmbs & \begin{tabular}{|l|} 
Hilex, Began in 1927 , St. \\
Paul, Minnesota and ended \\
production in 1970 s
\end{tabular} & & matches jars found in bag 8 , \\
\hline 5 & D & Brown Glass base & Glass & Kitchen & 1 & 27 & Bag 5, Level 2, 83-103 cmbs & Large "T" on base & & Unknown mark \\
\hline$\frac{5}{5}$ & $\mathrm{D}$ & \begin{tabular}{|l|} 
Flower pot \\
\end{tabular} & Ceramic & \begin{tabular}{|l} 
Household/ \\
Evuriture
\end{tabular} & 4 & 173 & Bag 5, Level 2, 83-103 cmbs & & & $\begin{array}{l}\text { Whiteware with yellowish glaze and } \\
\text { green raised leaves }\end{array}$ \\
\hline 5 & D & Sewage pipe & Ceramic & \begin{tabular}{|l|l|} 
Architecture \\
\end{tabular} & 1 & 3 & Bag 5, Level 2, 83-103 cmbs & & & brown salt glaze, seems burned \\
\hline 5 & $\mathrm{D}$ & Whiteware cup fragment & Ceramic & Kitchen & 2 & 15 & Bag 5, Level 2, 83-103 cmbs & Unknown & & \\
\hline 5 & D & \begin{tabular}{|l|}
$\begin{array}{l}\text { Whiteware fragment from large } \\
\text { boul }\end{array}$ \\
\end{tabular} & Ceramic & Kitchen & 2 & 66 & Bag 5, Level 2, 83-103 cmbs & Unknown & & \\
\hline 5 & $\mathrm{D}$ & Flower Pot & Ceramic & \begin{tabular}{|l|} 
Household / \\
Euriturd
\end{tabular} & 2 & 116 & Bag 5, Level 2, 83-103 cmbs & Unknown & & terracotta, light beige, soft paste \\
\hline 5 & $D$ & \begin{tabular}{|l|} 
Jug - Ceramic (stoneware) \\
\end{tabular} & Ceramic & Kitchen & & 2268 & Bag 5, Level 2, 83-103 cmbs & $\begin{array}{l}J-615^{n} \text { incised on side and } \\
615 \text { in a circle on base }\end{array}$ & & 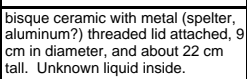 \\
\hline$\overline{6}$ & $6-1$ & \begin{tabular}{|l|l|} 
Adult shoe heel \\
\end{tabular} & Metal & Kitchen & & 8 & Bag 6, Level 3, 103-123 cmbs & Unknown & & \begin{tabular}{|l}
$\begin{array}{l}\text { Rectangular lid for spice can (holes } \\
\text { or shaking out spice) } 11 / 22^{*} \times 2 \\
\text { 1/14" }\end{array}$ \\
\end{tabular} \\
\hline 6 & $6-2$ & \begin{tabular}{|l|} 
Rectangular can base \\
\end{tabular} & Metal & Kitchen & & 5 & Bag 6, Level 3, 103-123 cmbs & Cin a triangle & & $23 / 16^{\prime \prime} \times 11 / 8^{\prime \prime}$ \\
\hline 6 & 6-3 & $\begin{array}{l}\text { Rectangular lid with oval } \\
\text { opening in center }\end{array}$ & Metal & Kitichen & & 10 & Bag 6, Level 3, 103-123 cmbs & & & $11 / 2^{\prime \prime} \times 21 / 4^{\prime \prime}$ \\
\hline 6 & $6-4$ & Rectangular metal lid or base & $\begin{array}{l}\text { Metal } \\
\end{array}$ & Kitchen & 1 & 11 & Bag 6, Level 3, 103-123 cmbs & Unknown & & $21 / 4^{\prime \prime} \times 11 / 2^{\prime \prime}$ \\
\hline$\overline{6}$ & $6-5$ & Mustard & 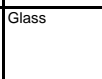 & Kitchen & & 166 & Bag 6, Level 3, 103-123 cmbs & $\begin{array}{l}\begin{array}{l}\text { Hover A-Hazel Atlas } \\
(1923-1964)\end{array} \\
\end{array}$ & 1923-1964 & 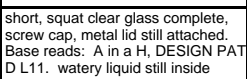 \\
\hline$\overline{6}$ & $6-6$ & Pepper Sauce Bottle & 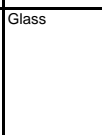 & Kitchen & & 142 & Bag 6, Level 3, 103-123 cmbs & $\begin{array}{l}\text { Jin a keystone- - Knox } \\
\text { Bottle Co.(1933-19953). } \\
\text { Jacksonville, MS plant }\end{array}$ & 1932-1953 & 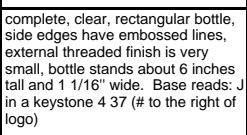 \\
\hline
\end{tabular}




\begin{tabular}{|c|c|c|c|c|c|c|c|c|c|c|}
\hline Lot\# & \begin{tabular}{|l} 
Unique \\
Item \#
\end{tabular} & Item Description & Material type & \begin{tabular}{|l|}
$\begin{array}{l}\text { Functional } \\
\text { Category }\end{array}$ \\
\end{tabular} & QTY & WT (G) & Provenience & Maker's Mark - maker & Date of mark & Notes \\
\hline 6 & 6 & Perfume/nail polish Bottle? & Glass & Grooming & 1 & 41 & Bag 6, Level 3, 103-123 cmbs & |Revlon & & 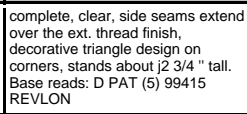 \\
\hline 6 & 6-8 & \begin{tabular}{|l|} 
Disney Figurine \\
\end{tabular} & Ceramic & Recreation & & 73 & Bag 6, Level 3, 103-123 cmbs & Disney & & 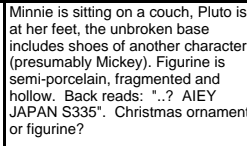 \\
\hline 6 & $6-9$ & Foundation Make-up bottle & Glass & Grooming & & 99 & Bag 6, Level 3, 103-123 cmbs & Unknown & & 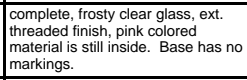 \\
\hline 6 & 6-D & Bottle base frag & Glass & Kitchen & 1 & 58 & Bag 6, Level 3, 103-123 cmbs & Unknown & & \begin{tabular}{|l} 
Clear glass, round, stippling, \\
possibly has numbers but too \\
blurred to read
\end{tabular} \\
\hline 6 & $6-10$ & Cologne Bottle & Glass & Grooming & & 88 & Bag 6, Level 3, 103-123 cmbs & \begin{tabular}{|l|}
$\begin{array}{l}\text { Owens-Illinois (1929- } \\
\text { presentt) }\end{array}$ \\
\end{tabular} & 1936 or 1946 & 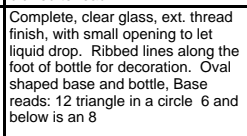 \\
\hline 6 & $6-11$ & $\begin{array}{l}\text { Vinegar bottle } \\
\end{array}$ & Glass & Kitchen & 1 & 284 & Bag 6, Level 3, 103-123 cmbs & $\begin{array}{l}\begin{array}{l}\text { Owens--llinois (1929- } \\
\text { present) }\end{array} \\
\end{array}$ & 1947 & $\begin{array}{l}\text { Smaller vinegar bottle, but } \\
\text { otherwise the same. Base reads: " } \\
\text { ot to the right of logo (diamonds-ova } \\
\text { 1) } 47 \text { to the leftif below is } 5 \text {, below } \\
\text { that is } 1555 \text {, with stippling } \\
\text { covering the base }\end{array}$ \\
\hline 6 & $6-12$ & condiment bottle? & Glass & Kitchen & & 287 & Bag 6, Level 3, 103-123 cmbs & 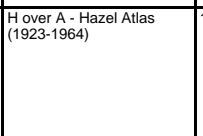 & $\begin{array}{ll}923-1964 \\
\end{array}$ & $\begin{array}{l}\text { Almost complete, clear glass bottle, } \\
\text { part of the ext threaded finish is } \\
\text { broken. } 14 \text { section panels that run } \\
\text { to shoulder of botlte. Base reads: } \\
7452 \text { below that is } A \text { inside an } \mathrm{H}: 0 \\
\text { to the left and } 7 \text { to the right and } 24 \\
\text { below. }\end{array}$ \\
\hline$\overline{6}$ & $\frac{6-13}{6-3}$ & Bottle base frag & Glass & Kitchen & & 35 & Bag 6, Level 3, 103-123 cmbs & 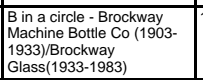 & $\begin{array}{ll}925-1964 \\
\end{array}$ & 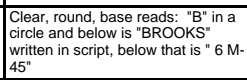 \\
\hline 6 & 6-14 & Indeterminate Glass Item & Glass & Unknown & 1 & 1 & Bag 6, Level 3, 103-123 cmbs & Unknown & & $\begin{array}{l}\text { glass tube, one end complete with } \\
\text { hole, possibly medical. Reminds } \\
\text { one of a syringe }\end{array}$ \\
\hline 6 & D & \begin{tabular}{|l|} 
Machine Part \\
\end{tabular} & Metal & Unknown & 1 & 256 & Bag 6, Level 3, 103-123 cmbs & Unknown & & cast iron, unknown function \\
\hline 6 & $\bar{D}$ & $\begin{array}{l}\text { Pulled wire nail } \\
\end{array}$ & Metal & Architecture & 25 & 129 & Bag 6, Level 3, 103-123 cmbs & Unknown & & ca.2 23/4" \\
\hline 6 & $\bar{D}$ & $\begin{array}{l}\text { Pulled wire nails } \\
\end{array}$ & Metal & \begin{tabular}{|l|l|l|l} 
Architecture \\
\end{tabular} & 3 & 42 & 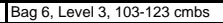 & Unknown & & \\
\hline 6 & D & Finishing nails & Metal & Architecture & 16 & 15 & Bag 6, Level 3, 103-123 cmbs & Unknown & & ca. $1.5^{\prime \prime}$ \\
\hline 6 & $\mathrm{D}$ & Cut wire nail & Metal & Architecture & 1 & 3 & Bag 6, Level 3, 103-123 cmbs & Unknown & & ca. $23 / 32^{\prime \prime}$ \\
\hline 6 & D & \begin{tabular}{|l|}
$\begin{array}{l}\text { Rusted tin cans and } \\
\text { unidentifiable scrap metal }\end{array}$ \\
\end{tabular} & Metal & Kitchen & & 5670 & Bag 6, Level 3, 103-123 cmbs & Unknown & & 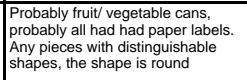 \\
\hline 6 & $\mathrm{D}$ & Tractor seat & Metal & Transportation & 1 & 1474 & Bag 6, Level 3, 103-123 cmbs & Unknown & & \\
\hline 6 & D & Motor Oil & \begin{tabular}{|c|c|c|} 
Metal \\
\end{tabular} & Transportation & 6 & 651 & Bag 6, Level 3, 103-123 cmbs & "GULF MOTOR OIL" & & $M N V=5$ \\
\hline 6 & $\mathrm{D}$ & Folger's Coffee Can Lids & Metal & Kitchen & 2 & 84 & Bag 6, Level 3, 103-123 cmbs & $\begin{array}{l}\text { J.A. Folger \& co, San } \\
\text { Francisco, CA since 1872, } \\
\text { in 1946 the elters are all } \\
\text { caps, by } 1956 \text { onsly the } \mathrm{F} \text { is } \\
\text { in capital letters. }\end{array}$ & & "FOLGER'S REGULAR" \\
\hline$\frac{6}{6}$ & $\frac{D}{D}$ & \begin{tabular}{|l|} 
Threaded Jar lids' \\
Coffee Can \\
\end{tabular} & \begin{tabular}{|l|l|} 
Metal \\
Metal
\end{tabular} & $\begin{array}{l}\text { Kitchen } \\
\text { Kitchen }\end{array}$ & $\frac{2}{3}$ & $\begin{array}{l}42 \\
369\end{array}$ & \begin{tabular}{|l|l|l|} 
Bag 6, Level 3, 103-123 cmbs \\
Bag 6, Level 3, 103-123 cmbs
\end{tabular} & \begin{tabular}{|l|} 
Unknown \\
J.A. Folger \& co, San \\
Francico, CA since 1872, \\
in 1944 the letters are all \\
caps, by 1956 only the Fis \\
in capital letters.
\end{tabular} & & \begin{tabular}{|l}
$\begin{array}{l}\text { red and white paint and lettering, } \\
\text { nautical scene (two boats) in center } \\
\text { circle as logo }\end{array}$ \\
\end{tabular} \\
\hline 6 & D & Motor oil & 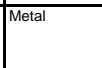 & Transportation & & 117 & Bag 6, Level 3, 103-123 cmbs & Unknown & & $\begin{array}{l}\text { taded paint, "AE 30" embossed on } \\
\text { lid, opened with church key, } \\
\text { perhaps used to have paper label }\end{array}$ \\
\hline 6 & D & Paint Can & Metal & Activities & 1 & 30 & Bag 6, Level 3, 103-123 cmbs & Unknown & & 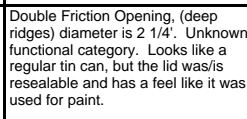 \\
\hline$\overline{6}$ & D & \begin{tabular}{|l|} 
Paint Can \\
\end{tabular} & 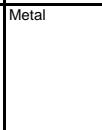 & Activities & & 86 & Bag 6, Level 3, 103-123 cmbs & Unknown & & 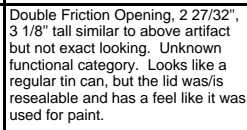 \\
\hline$\overline{6}$ & D & pop-off lid & 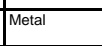 & Kitchen & & 24 & Bag 6, Level 3, 103-123 cmbs & Unknown & & $\begin{array}{l}27 / 8 " \text { diameter, too rusty to read if } \\
\text { ever said anything }\end{array}$ \\
\hline 6 & $\mathrm{D}$ & Tin enameled Bucket & Metal & Tools & 1 & 227 & Bag 6, Level 3, 103-123 cmbs & Unknown & & white with red strip along rim \\
\hline 6 & $\mathrm{D}$ & Battery & Composite & Tools & 1 & 110 & Bag 6, Level 3, 103-123 cmbs & Unknown & & size D \\
\hline 6 & D & Rubber Hose & Synthetic & Tools & 4 & 39 & Bag 6, Level 3, 103-123 cmbs & Unknown & & $\begin{array}{l}\text { black, possibly burned, possibly a } \\
\text { soaker hose }\end{array}$ \\
\hline$\frac{6}{6}$ & $D$ & \begin{tabular}{|l} 
Botle cap \\
Kotchun botte
\end{tabular} & \begin{tabular}{|l|l} 
Synthetic \\
Shasc
\end{tabular} & $\begin{array}{l}\text { Kitchen } \\
\text { Ktchon }\end{array}$ & $\frac{1}{10}$ & 5 & Bag 6, Level 3, 103-123 cmbs & \begin{tabular}{|l|l} 
Unknown \\
Hener
\end{tabular} & $1923-1964$ & \begin{tabular}{|l|} 
white, plastic and rubber \\
\end{tabular} \\
\hline $6^{6}$ & D & Ketchup bottle & Glass & Kitchen & & 301 & Bag 6, Level 3, 103-123 cmbs & $\begin{array}{l}\begin{array}{l}\text { Hover A- - azzel Atlas } \\
\text { (1923-1964) }\end{array} \\
\end{array}$ & 1923-1964 & $\begin{array}{l}\text { completet, clear glass, , Base reads : } \\
7406 \mathrm{~A} \text { in a } \mathrm{H} 15^{2}\end{array}$ \\
\hline 6 & D & \begin{tabular}{|l|} 
Jergens lotion \\
\end{tabular} & Glass & Grooming & 1 & 31 & Bag 6, Level 3, 103-123 cmbs & Jergens Lotion & & $\begin{array}{l}\text { "Jergens Lotion" embossed on base } \\
\text { of rectangular bottle, clear glass, } \\
\text { fragment, }\end{array}$ \\
\hline 6 & D & Vinegar bottle & Glass & Kitchen & 1 & 453 & Bag 6, Level 3, 103-123 cmbs & Unknown & & $\begin{array}{l}\text { Complete jar, clear glass, ext. } \\
\text { threeading finish, base reads: } 4425 \\
\text { K } 14-7\end{array}$ \\
\hline 6 & D & Window pane glass & Glass & Architecture & 5 & 36 & Bag 6, Level 3, 103-123 cmbs & Unknown & & \\
\hline
\end{tabular}




\section{Archeological Testing of the Engstrand Well 41WM1157, in Williamson County, Texas}

\begin{tabular}{|c|c|c|c|c|c|c|c|c|c|c|}
\hline Lot\# & \begin{tabular}{|l|l} 
Unique \\
Item \#
\end{tabular} & |ltem Description & Material type & \begin{tabular}{|l} 
Functional \\
Category
\end{tabular} & QTY & WT (G) & Provenience & Maker's Mark - maker & Date of mark & Notes \\
\hline 6 & D & Bottle base frag & Glass & |Kitchen & 1 & 66 & Bag 6, Level 3, 103-123 cmbs & \begin{tabular}{|l} 
Owens-Illinois (1929- \\
present)
\end{tabular} & 1934 or 1944 & $\begin{array}{l}\text { Clear glass, round, } 15 \text { to the left of } \\
\text { the logo, } 4 \text { t the right, 3e below } \\
\text { DES PAT RE 2191??" with stippling }\end{array}$ \\
\hline 6 & D & Base-clear glass bottle frag & Glass & Kitchen & 1 & 44 & Bag 6, Level 3, 103-123 cmbs & $\begin{array}{l}\text { Owens-Illinois (1929- } \\
\text { present) }\end{array}$ & 1934 or 1944 & $\begin{array}{l}\text { Clear glass, round, } 15 \text { to the elft of } \\
\text { the logo, } 4 \text { to the right, } 14 \text { below. }\end{array}$ \\
\hline 6 & D & Base-clear glass bottle frag & Glass & Kitchen & 1 & 47 & Bag 6, Level 3, 103-123 cmbs & $\begin{array}{l}\text { Hover A- Hazel Atlas } \\
(1923-1964)\end{array}$ & \begin{tabular}{|c|}
$1923-1964$ \\
\end{tabular} & $\begin{array}{l}\text { Clear glass, round, Base reads: 6-2 } \\
\text { abovevogo (A inside an H) and } \\
\text { K } 46434 \text { below }\end{array}$ \\
\hline 6 & D & Base - clear glass bottle frag & Glass & Kitchen & 1 & 59 & Bag 6, Level 3, 103-123 cmbs & $\mid \begin{array}{l}\text { Hover A- Hazel Atlas } \\
(1923-1964)\end{array}$ & 1923-1964 & $\begin{array}{l}\text { Clear glass, round Base reads: } 3-6.6 \\
\text { abovev logo }(\mathrm{A} \text { inside an } \mathrm{H} \text { ) and } 634 \\
\text { below. }\end{array}$ \\
\hline 6 & D & Base clear glass bottle frag & Glass & Kitchen & 1 & 85 & Bag 6, Level 3, 103-123 cmbs & \begin{tabular}{|l|} 
Ball liltothers Company \\
(1888-1996), Muncie, IN \\
(lockhart, 200, appendix D)
\end{tabular} & 1919-1969 & $\begin{array}{l}\text { Clear glass, round, base reads: 16- } \\
\text { ?? Above logo ("BALL" in script) }\end{array}$ \\
\hline 6 & D & Base-clear glass bottle frag & Glass & Kitchen & 1 & 76 & Bag 6, Level 3, 103-123 cmbs & \begin{tabular}{|l}
$\begin{array}{l}\text { Owens-Illinois (1929- } \\
\text { present) }\end{array}$ \\
\end{tabular} & 1937 & 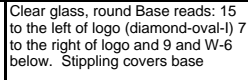 \\
\hline 6 & D & Bottle base frag & Glass & Kitchen & 1 & 51 & Bag 6, Level 3, 103-123 cmbs & \begin{tabular}{|l|} 
Ball Brothers Company \\
(11888-1996), Muncie, IN \\
(lockhart, 200, appendix D)
\end{tabular} & 1919-1969 & $\begin{array}{l}\text { Clear glass, round Base reads: } 5 \\
\text { PAT } 105251 \text { abovev logo (BALL } \\
\text { written in script) }\end{array}$ \\
\hline 6 & D & Bottle base frag & Glass & Kitchen & 1 & 6 & Bag 6, Level 3, 103-123 cmbs & \begin{tabular}{|l|} 
Duraglas (1940+) - Owens- \\
Ilinois (1929-present)
\end{tabular} & $1940+$ & $\begin{array}{l}\text { Clear glass, round "Duraglas" in } \\
\text { script is along foot of bottle }\end{array}$ \\
\hline 6 & D & Bottle base frag & Glass & Kitchen & 1 & 48 & Bag 6, Level 3, 103-123 cmbs & $\begin{array}{l}\text { Owens-Illinois (1929- } \\
\text { present) }\end{array}$ & 1937 & \begin{tabular}{|l} 
Clear glass, round, Base reads: 15 \\
to the left of logo (diamonddo-oral-1) \\
with 7 to the right of logo and 10 \\
below.
\end{tabular} \\
\hline 6 & D & Bottle base frag & Glass & Kitchen & 1 & 23 & Bag 6, Level 3, 103-123 cmbs & Unknown & & \begin{tabular}{|l} 
Clear glass, round, $40 \%$ of base \\
intact. "W-9" with stippling
\end{tabular} \\
\hline 6 & D & Bottle base frag & Glass & Kitchen & 1 & 32 & Bag 6, Level 3, 103-123 cmbs & Unknown & & \begin{tabular}{|l|} 
Clear glass, round, base reads: \\
"as58"
\end{tabular} \\
\hline 6 & D & Bottle base frag & Glass & Kitchen & 1 & $\sqrt{35}$ & Bag 6, Level 3, 103-123 cmbs & $\begin{array}{l}\text { Sin a keystone- Knox } \\
\text { Bottle Co. (1932-1953)- } \\
\text { Jacksonville, MS plant }\end{array}$ & 1932-1953 & $\begin{array}{l}\text { Clear, round, Base reads: } 15 \text { above } \\
\text { logog ( I I in a keystone) and } 4422 \text { to } \\
\text { the right }\end{array}$ \\
\hline 6 & D & Bottle base frag & Glass & Kitchen & 1 & 88 & Bag 6, Level 3, 103-123 cmbs & \begin{tabular}{|l|}
$\begin{array}{l}\text { Anchor Hocking (1937- } \\
\text { present) }\end{array}$ \\
\end{tabular} & & \begin{tabular}{|l} 
clear glass, round, Base reads: 50- \\
76 above logo ( $\mathrm{H}$ over an anchor \\
design)
\end{tabular} \\
\hline 6 & D & light cobalt blue glass & Glass & \begin{tabular}{|l}
$\begin{array}{l}\text { Household// } \\
\text { Furniture }\end{array}$ \\
\end{tabular} & 5 & 53 & Bag 6, Level 3, 103-123 cmbs & $\begin{array}{l}\text { Philips Milk of Magnesia, } \\
\text { Glentrook, Conn. }\end{array}$ & $\begin{array}{l}\text { Philips Milik of } \\
\text { mangesia reached the } \\
\text { market in } 1873 \text {, also } \\
\text { made toothpaste }\end{array}$ & 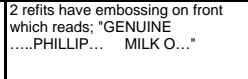 \\
\hline 6 & D & Blue glass & Glass & $\begin{array}{l}\text { Household// } \\
\text { Furniture }\end{array}$ & 3 & 2 & Bag 6, Level 3, 103-123 cmbs & Unknown & & $\begin{array}{l}\text { super light weight thin, transparent } \\
\text { glass or plastic }\end{array}$ \\
\hline \begin{tabular}{|l}
6 \\
6
\end{tabular} & $\frac{D}{D}$ & \begin{tabular}{|l} 
Unmarked brown glass \\
Bronn glass body Fragment \\
\end{tabular} & Glass & \begin{tabular}{|l|l} 
Kitchen \\
Kitthen
\end{tabular} & $\frac{20}{1 .}$ & 149 & Bag 6, Level 3, 103-123 cmbs & $\begin{array}{ll}\text { Unknown } \\
\text { non ne }\end{array}$ & & \\
\hline$D^{\circ}$ & ]$^{0}$ & Brown glass body Fragment & |Giass & Jilchen & T & $D^{8}$ & Bag 6, Level 3, 103-123 cmbs & |"... о O..." & & \\
\hline 6 & D & Dark red glass, possibly a plate & Glass & Kitchen & 1 & $1^{10}$ & Bag 6, Level 3, 103-123 cmbs & Unknown & & \\
\hline 6 & D & Canning Jar & Glass & Kitchen & $2^{2}$ & 35 & Bag 6, Level 3, 103-123 cmbs & 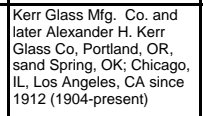 & 1909-present & $\begin{array}{l}\text { "Ke.. (in script) GLASS } \\
\text { TTPP...MASON" clear glass, body } \\
\text { frag, }\end{array}$ \\
\hline 6 & D & Light bulb base fragment & Glass & $\begin{array}{l}\text { Household/ } \\
\text { Furniture }\end{array}$ & 1 & 19 & Bag 6, Level 3, 103-123 cmbs & Unknown & & \\
\hline 6 & D & Olive green glass frag & Glass & Kitchen & 1 & 5 & Bag 6, Level 3, 103-123 cmbs & Unknown & & \\
\hline 6 & $D$ & Milk glass frag & Glass & Grooming & 1 & 23 & Bag 6, Level 3, 103-123 cmbs & Unknown & & round, plain, cold cream jar? \\
\hline 6 & D & Jar neck frag & Glass & Kitchen & 7 & 146 & \begin{tabular}{|l} 
Bag 6, Level 3, $103-123 \mathrm{cmbs}$ \\
\end{tabular} & Unknown & & Ext. thread finish, clear glass \\
\hline 6 & D & Bottle neck frags & Glass & Kitchen & $3^{3}$ & 87 & Bag 6, Level 3, 103-123 cmbs & Junkown & & $\begin{array}{l}\text { Exxt thereaded, llaear glass, seams } \\
\text { extend over top of lip }\end{array}$ \\
\hline 6 & D & Bottle neck frags & Glass & Kitchen & 1 & 60 & Bag 6, Level 3, 103-123 cmbs & Unknown & & $\begin{array}{l}\text { equal to ketchup bottle finish from } \\
\text { Lot } 6 \text { t }-10\end{array}$ \\
\hline 6 & D & Clear glass body fragments & Glass & Kitchen & 202 & $\begin{array}{l}1,917 \\
-19\end{array}$ & Bag 6, Level 3, 103-123 cmbs & Unknown & & \\
\hline 6 & D & Clear glass body fragments & Glass & Kitchen & 1 & 17 & Bag 6, Level 3, 103-123 cmbs & \begin{tabular}{|l|}
\begin{tabular}{|} 
Anchor Hocking (1937- \\
present)
\end{tabular} \\
\end{tabular} & $1937+$ & "ANCHOR" on foot of bottle \\
\hline 6 & D & Clear glass body fragments & Glass & Kitchen & 1 & 12 & Bag 6, Level 3, 103-123 cmbs & \begin{tabular}{|l|} 
Duraglas (1940+) - Owens- \\
Illinois (1929-present)
\end{tabular} & $1940+$ & $\begin{array}{l}\text { "Dura" in script along foot of } \\
\text { fragment }\end{array}$ \\
\hline 6 & D & ACL drinking glasses & Glass & Kitchen & 13 & 137 & Bag 6, Level 3, 103-123 cmbs & Unknown & & 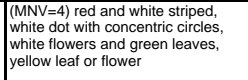 \\
\hline 6 & D & Consumable bottle with $\mathrm{ACL}$ & Glass & Kitchen & 1 & 22 & Bag 6, Level 3, 103-123 cmbs & $\begin{array}{l}\text { Sandahl Beverage - } \\
\text { SunTex }\end{array}$ & & 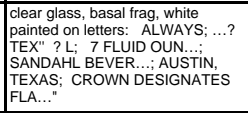 \\
\hline 6 & D & Consumable bottle with $\mathrm{ACL}$ & Glass & Kitchen & 1 & 10 & Bag 6, Level 3, 103-123 cmbs & $\begin{array}{l}\text { Sandahl Beverage - } \\
\text { SunTex }\end{array}$ & & 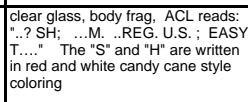 \\
\hline 6 & D & Consumable bottle with $\mathrm{ACL}$ & Glass & Kitchen & 1 & 8 & Bag 6, Level 3, 103-123 cmbs & Unknown & & "eu" in yellow script \\
\hline 6 & D & Nozzle & Metal & Tool & 1 & 7 & Bag 6, Level 3, 103-123 cmbs & Unknown & & \begin{tabular}{|l} 
Unknown metal, external threading \\
cap, probabably was attached to a \\
tube of sorts
\end{tabular} \\
\hline 6 & D & Flower Pot & Ceramic & $\begin{array}{l}\begin{array}{l}\text { Household } / \\
\text { Furniture }\end{array} \\
\end{array}$ & 5 & 139 & Bag 6, Level 3, 103-123 cmbs & |Unknown & & \begin{tabular}{|l|} 
Beige/yellow glazing with raised \\
green leaves on whiteware
\end{tabular} \\
\hline 6 & D & Flower Pot & Ceramic & $\begin{array}{l}\text { Household/ } \\
\text { Furniture }\end{array}$ & 13 & 301 & Bag 6, Level 3, 103-123 cmbs & Unknown & & Bisque terracotta \\
\hline 6 & D & Plain whiteware & Ceramic & Kitchen & 4 & 111 & Bag 6, Level 3, 103-123 cmbs & Unknown & & \begin{tabular}{|l|l|} 
Bowl fragments \\
\end{tabular} \\
\hline 6 & D & Plain whiteware & Ceramic & Kitchen & 1 & 21 & Bag 6, Level 3, 103-123 cmbs & Unknown & & $\begin{array}{l}\text { Cup fragments-(place where handle } \\
\text { has broken off) molded flower } \\
\text { design }\end{array}$ \\
\hline 6 & D & Plain whiteware & Ceramic & Kitchen & 5 & 102 & Bag 6, Level 3, 103-123 cmbs & Unknown & & $\begin{array}{l}\text { Cup fragments with molded design } \\
\text { along base }\end{array}$ \\
\hline 6 & D & 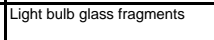 & Glass & \begin{tabular}{|l} 
Household \\
Furniture
\end{tabular} & 4 & 3 & Bag 6, Level 3, 103-123 cmbs & Unknown & & \\
\hline & 7-1 & Pop-off lid with shaker holes & Metal & Kitchen & & 8 & Bag 7, Level 4, $123-143 \mathrm{cmbs}$ & & & fits into lot 7-2 \\
\hline
\end{tabular}




\begin{tabular}{|c|c|c|c|c|c|c|c|c|c|c|}
\hline Lot\# & \begin{tabular}{|l} 
Unique \\
Item\#\#
\end{tabular} & Item Description & Material type & \begin{tabular}{|l|}
$\begin{array}{l}\text { Functional } \\
\text { Category }\end{array}$ \\
\end{tabular} & QTY & WT (G) & Provenience & Maker's Mark - maker & Date of mark & Notes \\
\hline 7 & $77^{7-2}$ & Ketchup bottle & Glass & Kitchen & 1 & 288 & Bag 7, Level 4, 123-143 cmbs & $\begin{array}{l}\text { Owens-llinois (1929-- } \\
\text { presentt) }\end{array}$ & $1937 ?$ & 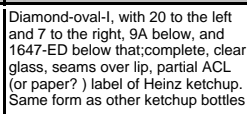 \\
\hline & $\overline{7-3}$ & Medical bottle & Glass & Medical & 1 & 113 & Bag 7, Level 4, 123-143 cmbs & & & 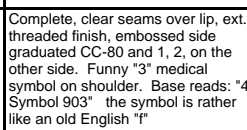 \\
\hline & $7-4$ & cologne? & Glass & Grooming & 1 & 159 & Bag 7, Level 4, $123-143 \mathrm{cmbs}$ & $\begin{array}{l}\text { J in a keystone- Knox } \\
\text { Bottle Co. (1932-1953)- } \\
\text { Jacksonville, MS plant }\end{array}$ & $1932-1953$ & 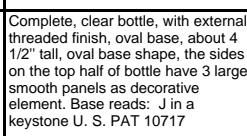 \\
\hline & 77 & Vanilla extract? & Glass & Kitchen & 1 & 48 & & & & 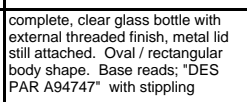 \\
\hline & $7-6$ & Ketchup bottle & Glass & Kitchen & 1 & 284 & Bag 7, Level 4, 123-143 cmbs & $\begin{array}{l}\text { Hover A-Hazel Atlas } \\
(1923-1964)\end{array}$ & 1923-1964 & 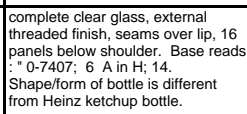 \\
\hline & $7-7$ & Canning Jar & Glass & Kitchen & 1 & 209 & Bag 7, Level 4, 123-143 cmbs & \begin{tabular}{|l|} 
Duraglas (1940+)- - Owens- \\
llinois (1929-present)
\end{tabular} & $1940+$ & $\begin{array}{l}\text { clear glass, complete, external } \\
\text { threaded finish, "Duraglas" in script } \\
\text { on toot. Base reads; " unreadabale } \\
\text { numbers and diamond-ovall. } \\
\text { Stippling covers the basea, luuring } \\
\text { the maker's mark }\end{array}$ \\
\hline 7 & $7-8$ & Decorative glass & Glass & \begin{tabular}{|l|} 
Householdd/ \\
Furniture
\end{tabular} & 1 & 26 & Bag 7, Level 4, 123-143 cmbs & & & $\begin{array}{l}\begin{array}{l}\text { Matches light blue decorative glass } \\
\text { from bag } 9\end{array} \\
\text { int }\end{array}$ \\
\hline & 7-D & Brown bottle with lid & Composite & Medical & 1 & 337 & \begin{tabular}{|c|} 
Bag 7, Level 4, $123-143$ cmbs \\
\end{tabular} & \begin{tabular}{|l|} 
MTC- - Thatcher \\
Manufacturing Corp. (1904- \\
1985)
\end{tabular} & 1923-1950's or 1949+ & 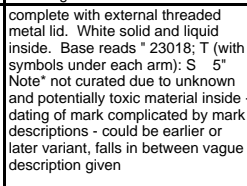 \\
\hline & 7-D & Bottle base frag & Glass & Kitchen & 1 & 26 & Bag 7, Level 4, 123-143 cmbs & $\begin{array}{l}\text { Owens-llinois (1929- } \\
\text { present) }\end{array}$ & 1936? & $\begin{array}{l}\text { Diamond-oval-1 with } 7 \text { to the left, }, 6 \\
\text { to the right, } 3 \text { below. Clear glass } \\
\text { and round base shape }\end{array}$ \\
\hline & 7-D & Bottle base frag & Glass & Kitchen & 1 & 76 & Bag 7, Level 4, 123-143 cmbs & $\begin{array}{l}\begin{array}{l}\text { Hover A-Hazel Atlas } \\
(1923-1964)\end{array} \\
\text { (1) A }\end{array}$ & 1923-1964 & $\begin{array}{l}\text { Ain H with } 4625 \text { above, } A \text { and } 12 \\
\text { below logo }\end{array}$ \\
\hline & 7-D & Clear glass body fragments & Glass & Kitchen & 77 & 822 & Bag 7, Level 4, 123-143 cmbs & & & $\begin{array}{l}\text { leblow logo } \\
\text { some have molded ridges or } \\
\text { stippling, one has wheat pattern, } \\
\text { line with embossed pattean rather } \\
\text { like a football or shoe }\end{array}$ \\
\hline & 7-D & Unmarked brown glass & Glass & Kitchen & 6 & 80 & Bag 7, Level 4, 123-143 cmbs & & & \\
\hline 7 & 7-D & $\begin{array}{l}\text { Clear glass neck frag with } \\
\text { metal screw cap attached }\end{array}$ & Glass & Kitchen & 1 & 35 & Bag 7, Level 4, 123-143 cmbs & & & \\
\hline 7 & $7-D$ & \begin{tabular}{|l} 
Brown nlass neck fag with \\
metat screw cap attached
\end{tabular} & Glass & Kitchen & 1 & 32 & Bag 7, Level 4, 123-143 cmbs & & & \\
\hline 7 & $\mathrm{D}$ & Metal oilkerosenene refillable can & Metal & Transportation & 1 & 361 & Bag 7, Level 4, 123-143 cmbs & Unknown & & $\begin{array}{l}\text { fairly large, round, ridged sides, } \\
\text { tarndeger }\end{array}$ \\
\hline 7 & D & Motor oil can & Metal & \begin{tabular}{|l|} 
Transportation \\
\end{tabular} & 4 & 378 & Bag 7, Level 4, 123-143 cmbs & Gulf motor oil & & \begin{tabular}{|l} 
same as others, 2 almost complete, \\
2 frags)
\end{tabular} \\
\hline 7 & D & Metal file fragment & Metal & \begin{tabular}{|l|} 
Tool \\
\end{tabular} & 1 & 279 & Bag 7, Level 4, $123-143$ cmbs & Unknown & & slightly bent possibly burned \\
\hline & D & Texas License Plate & Metal & Transportation & 4 & $\mid 112$ & Bag 7, Level 4, 123-143 cmbs & \begin{tabular}{|l} 
Texas Prisons \\
\end{tabular} & & 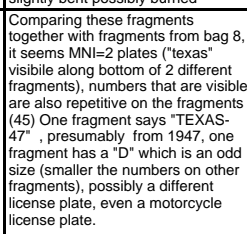 \\
\hline & $\mathrm{D}$ & Paint Can & Metal & Activities & 1 & 97 & Bag 7, Level 4, 123-143 cmbs & Unknown & & double friction lid \\
\hline & D & Metal screw cap lid & Metal & Kitchen & 1 & 20 & Bag 7, Level 4, 123-143 cmbs & Unknown & & for a glass jar \\
\hline & D & Polish Container & Metal & 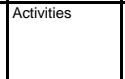 & 1 & 114 & Bag 7, Level 4, 123-143 cmbs & Unknown & & 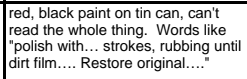 \\
\hline & D & Misc. Wire & Metal & Unknown & 4 & 76 & Bag 7, Level 4, $123-143 \mathrm{cmbs}$ & & & average $4 \mathrm{~mm}$ thick \\
\hline & $\mathrm{D}$ & Pulled wire nail & Metal & \begin{tabular}{|l|l|} 
Archititecture \\
\end{tabular} & $\frac{76}{16}$ & 83 & Bag 7, Level $4,123-143$ cmbs & & & ca. 2.5 "long \\
\hline & $\mathrm{D}$ & Finishing Nails-Pulled wire & Metal & Architecture & 5 & 4 & Bag 7, Level 4, 123-143 cmbs & & & $2.5^{\mathrm{m}}$ long \\
\hline & $\mathrm{D}$ & & Metal & Unknown & 1 & 161 & Bag 7, Level 4, 123-143 cmbs & & & Railroad? Fragment, iron \\
\hline & $\mathrm{D}$ & Unknown metal & Metal & Unknown & 1 & 4 & Bag 7, Level 4, 123-143 cmbs & & & \\
\hline & $\mathrm{D}$ & Rectangular tin can & Metal & kitchen & 1 & 5 & Bag 7, Level 4, 123-143 cmbs & & & just the top/ bottom seam remains \\
\hline 7 & D & $\begin{array}{l}\text { Tin cans and unidentifiable } \\
\text { metal fragments }\end{array}$ & Metal & kitchen & & 1950 & Bag 7, Level 4, $123-143 \mathrm{cmbs}$ & & & \\
\hline & D & Pry-off tin can lid fragment & Metal & Kitchen & 1 & 6 & Bag 7, Level 4, 123-143 cmbs & & & \\
\hline & D & Plastic threaded cap & Synthetic & Kitchen & 1 & 1 & Bag 7, Level 4, 123-143 cmbs & & & red \\
\hline & $\mathrm{D}$ & Unknown black plastic cover & Synthetic & Unknown & 1 & 87 & Bag 7, Level 4, 123-143 cmbs & $\begin{array}{l}\text { front reads: "WICO; } \\
\text { SERIES AP" }\end{array}$ & & to a machine part? \\
\hline & D & Plastic washer & Synthetic & Tool & 1 & 2 & Bag 7, Level 4, 123-143 cmbs & & & \\
\hline
\end{tabular}


50 Archeological Testing of the Engstrand Well 41WM1157, in Williamson County, Texas

\begin{tabular}{|c|c|c|c|c|c|c|c|c|c|c|}
\hline Lot\# & \begin{tabular}{|l} 
Unique \\
litem \#
\end{tabular} & Item Description & Material type & \begin{tabular}{|l}
$\begin{array}{l}\text { Functional } \\
\text { Category }\end{array}$ \\
\end{tabular} & QTY & WT (G) & Provenience & Maker's Mark - maker & Date of mark & Notes \\
\hline 7 & D & Spark plug & Composite & Transportation & 1 & 63 & Bag 7, Level 4, 123-143 cmbs & & & porcelain, metal \\
\hline & $\mathrm{D}$ & Spark plug & Composite & Transportation & & 35 & Bag 7, Level 4, 123-143 cmbs & & & $\begin{array}{l}\text { metal rod or wire through tubular } \\
\text { semi-porcelain }\end{array}$ \\
\hline & D & Concrete & Ceramic & Architecture & 1 & 24 & Bag 7, Level 4, $123-143 \mathrm{cmbs}$ & & & \\
\hline & D & Jnknown, white chalk-lime? & mineral & Jnknown & & 66 & Bag 7, Level 4, 123-143 cmbs & & & \\
\hline 7 & D & Rectangular tin can container & Metal & Kitchen & 1 & 66 & Bag 7, Level 4, 123-143 cmbs & & & 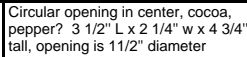 \\
\hline & D & Spoon & Metal & Kitchen & 1 & 46 & Bag 7, Level 4, $123-143 \mathrm{cmbs}$ & & & table spoon \\
\hline & D & Rectangular tin can lid or base & Metal & Kitchen & 1 & 17 & |Bag 7, Level 4, 123-143 cmbs & & & 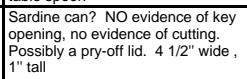 \\
\hline 7 & D & Cut wire nail & Metal & Architecture & 1 & 111 & Bag 7, Level 4, 123-143 cmbs & & & \begin{tabular}{|l} 
bent at 45 degree angle at end, long \\
over $311 / 2$ "long
\end{tabular} \\
\hline 7 & D & Fork & Metal & Kitchen & 1 & 12 & Bag 7, Level 4, 123-143 cmbs & & & $\begin{array}{l}\text { stainless steel, just top half, made to to } \\
\text { fit into a handle of different material }\end{array}$ \\
\hline 7 & D & Clear glass neck frag with cap & Composite & Kitchen & 1 & 32 & Bag 7, Level 4, 123-143 cmbs & Heinz Ketchup & & $\begin{array}{l}\text { External threaded finish, painted } \\
\text { white aluminum cap with "H...?; } \\
57 \text { : VARIE..." }\end{array}$ \\
\hline & D & Cologne Bottle? & Glass & Grooming & & 160 & Bag 7, Level 4, 123-143 cmbs & $\begin{array}{l}\text { Sin a circle on base- } \\
\text { Swindnell Bros. (?)(1869- } \\
\text { 1959) }\end{array}$ & 1920-1959 & 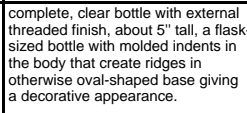 \\
\hline & D & Vinegar bottle & Glass & Kitchen & & 276 & & \begin{tabular}{|l|} 
Duraglas (1940+)- Owens- \\
Illinois (1929-present)
\end{tabular} & 1947 & 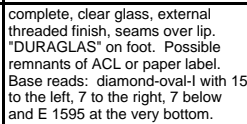 \\
\hline & D & Vinegar bottle & Glass & Kitchen & 1 & 280 & Bag 7, Level 4, $123-143 \mathrm{cmbs}$ & $\begin{array}{l}\text { Hover A- Hazel Atlas } \\
(1923-1964)\end{array}$ & 1923-1964 & 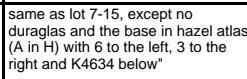 \\
\hline $7^{7}$ & D & Canning Jar & Glass & Kitchen & 1 & 285 & Bag 7, Level 4, 123-143 cmbs & $\begin{array}{l}\text { Ball brothers Company, } \\
\text { Muncie, IN }\end{array}$ & 1919-1969 & 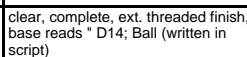 \\
\hline $7^{7}$ & D & Canning Jar & Glass & Kitchen & 1 & 228 & Bag 7, Level 4, 123-143 cmbs & $\begin{array}{l}\begin{array}{l}\text { Hover A- Hazel Atlas } \\
(1923-1964)\end{array} \\
\end{array}$ & 1923-1964 & 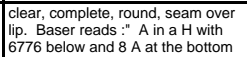 \\
\hline & $\mathrm{D}$ & small mouth bottle or jar & Glass & Kitchen & & 268 & & & & $\begin{array}{l}\text { clear, complete, round, external } \\
\text { threadedd tinish, sidis seams over top } \\
\text { of lip, plain, no markings }\end{array}$ \\
\hline 7 & D & Bottle base frag & Glass & Kitchen & 1 & 34 & & $\begin{array}{l}\text { Owens-Illinois (1929- } \\
\text { present) }\end{array}$ & 1937? & $\begin{array}{l}\text { clear, round, base has diamond- } \\
\text { oval- with } 5 \text { t to the left and } 7 \text { to the } \\
\text { right and } E 1602 \text { below }\end{array}$ \\
\hline $7^{7}$ & D & Jar finishes & Glass & Kitchen & 6 & 85 & Bag 7, Level 4, 123-143 cmbs & & & all are external threaded finishes \\
\hline & D & Bottle finishes & Glass & Kitchen & 3 & 83 & Bag 7, Level 4, 123-143 cmbs & & & \begin{tabular}{|l} 
all are external threaded finishes \\
and clear glass with side seams \\
over top of lip
\end{tabular} \\
\hline & D & Preserve ware jar & Glass & Kitchen & 1 & 82 & Bag 7, Level 4, 123-143 cmbs & & & $\begin{array}{l}\text { clear glass, tall cylinder, external } \\
\text { threaded finish, seams over top, no } \\
\text { base attached. }\end{array}$ \\
\hline $7^{7}$ & D & large clear glass bottle base & Glass & Kitchen & $\overline{1}$ & 210 & Bag 7, Level 4, 123-143 cmbs & \begin{tabular}{|l} 
Jin a keystone - Knox \\
Bottle Co. (1932-1953). \\
Jacksonville, MS plant
\end{tabular} & $1932-1953$ & J in a keystone with 442 to the right \\
\hline 7 & D & Base frag & Glass & Kitchen & 1 & 210 & Bag 7, Level 4, 123-143 cmbs & $\begin{array}{l}\text { Bin a circle - Brockway } \\
\text { Machine Botle Co (1903- } \\
\text { 1933)/Bockway } \\
\text { Glass(1933-1983) }\end{array}$ & 1925 & $\begin{array}{l}\text { clear glass, round shape, base } \\
\text { reads : 10-7.77; } 5 \mathrm{~B} \text { in a circle and } \mathrm{M} \\
77 \text { below logo }\end{array}$ \\
\hline 7 & D & Base frag & Glass & Kitchen & 1 & 46 & Bag 7, Level 4, 123-143 cmbs & \begin{tabular}{|l|} 
Duraglas (1940+) - Owens- \\
Illinois (1929-present)
\end{tabular} & 1947 & 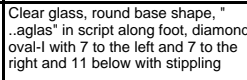 \\
\hline 7 & $\mathrm{D}$ & Brown basal frag & Glass & Kitchen & 1 & 111 & Bag 7, Level 4, 123-143 cmbs & \begin{tabular}{|l} 
Duraglas (1940+)- Owens- \\
lilinois (1929-present)
\end{tabular} & 1947 & $\begin{array}{l}\text { "Duraglas" in script along foot, } \\
\text { Diamond-oval-1 with } 7 \text { to the elett, } 7 \\
\text { to the right, and } 17 \text { below with } \\
\text { stippling }\end{array}$ \\
\hline 7 & D & Hi-lex basal frag & Glass & Activities & 1 & 56 & Bag 7, Level 4, 123-143 cmbs & Hi-lex & & $\begin{array}{l}\text { round base, brown glass, base } \\
\text { reads : :..lex; U.S. PAT. OFF. } \\
\text { Matches bag } 8 .\end{array}$ \\
\hline 7 & $\mathrm{D}$ & Hi-lex body frag & Glass & Activities & 1 & 32 & Bag 7, Level 4, $123-143 \mathrm{cmbs}$ & Hi-lex & & $\begin{array}{l}\text { "ONE HALF" and stippling, matches } \\
\text { complete bottles from bag } 8\end{array}$ \\
\hline 7 & D & Blue glass & Glass & Medical & 1 & 2 & Bag 7, Level 4, 123-143 cmbs & Phillips Milk of Magnesia & & matches " genuine Phillip" \\
\hline 7 & D & ACL marked drinking glasses & Glass & Kitchen & 5 & 49 & Bag 7, Level 4, 123-143 cmbs & & & \begin{tabular}{|l} 
clear glass, white flowers with green \\
leaves; red and white striped with \\
wide ridges, 3 with \\
undistinguishable and small spots o \\
color
\end{tabular} \\
\hline 7 & D & Unknown metal & Metal & Unknown & 1 & 18 & Bag 7, Level 4, 123-143 cmbs & & & looks like an electric plug end \\
\hline 7 & D & Flower Pot & ceramic & $\begin{array}{l}\text { Household/ } \\
\text { Furniture }\end{array}$ & $\frac{2}{2}$ & 206 & Bag 7, Level 4, 123-143 cmbs & & & $\begin{array}{l}\text { beige and y yillow with raised green } \\
\text { leaves, white ware }\end{array}$ \\
\hline 7 & D & Flower Pot & ceramic & $\begin{array}{l}\text { Household// } \\
\text { Furniture }\end{array}$ & 1 & 134 & Bag 7, Level 4, 123-143 cmbs & & & \begin{tabular}{|l|}
$\begin{array}{l}\text { small statter planter, bisque light } \\
\text { colored terra cottla. Complete pot, } \\
\text { about } 3 \text { 3" tall }\end{array}$ \\
\end{tabular} \\
\hline 7 & D & Flower Pot & ceramic & \begin{tabular}{|l} 
Household/ \\
Furniture
\end{tabular} & 2 & 51 & Bag 7, Level 4, 123-143 cmbs & & & \begin{tabular}{|} 
bisque terra cotta, matches frags \\
from other levels
\end{tabular} \\
\hline 7 & D & Plain whiteware cup frag & ceramic & Kitchen & 1 & 18 & Bag 7, Level 4, 123-143 cmbs & & & $\begin{array}{l}\text { molded/ /raised geometric design } \\
\text { along base, matches other levels }\end{array}$ \\
\hline 7 & D & Plain whiteware plate frag & ceramic & Kitchen & 2 & 52 & Bag 7, Level 4, $123-143 \mathrm{cmbs}$ & & & \\
\hline 8 & 8-1 & Spice can & Metal & Kitchen & 1 & 41 & Bag 8, Level 5, 143-163 cmbs & & & 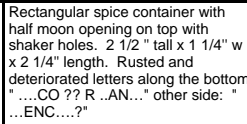 \\
\hline
\end{tabular}




\begin{tabular}{|c|c|c|c|c|c|c|c|c|c|c|}
\hline Lot \# & \begin{tabular}{|l} 
Unique \\
Item \#
\end{tabular} & |tem Description & Material type & \begin{tabular}{|l}
$\begin{array}{l}\text { Functional } \\
\text { Category }\end{array}$ \\
\end{tabular} & QTY & WT (G) & Provenience & Maker's Mark - maker & Date of mark & Notes \\
\hline 8 & 8-2 & SunTex Soda bottle & Glass & |Kitchen & 1 & 337 & Bag 8, Level 5, 143-163 cmbs & 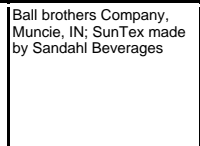 & |1919-1969 & 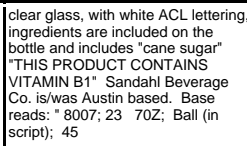 \\
\hline 8 & $8-3$ & Unknown Glass bottle & Glass & Kitchen & 1 & 157 & Bag 8, Level 5, 143-163 cmbs & & & 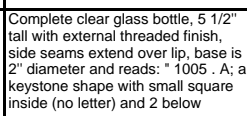 \\
\hline 8 & $8-4$ & Flavoring, perfume, hair oil? & Glass & Grooming & 1 & 121 & Bag 8, Level 5, 143-163 cmbs & & & 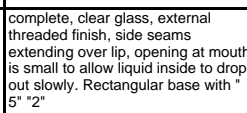 \\
\hline 8 & $8-5$ & Poison? & Glass & $\begin{array}{l}\text { Medical? } \\
\text { Activity? }\end{array}$ & 1 & 34 & Bag 8, Level 5, $143-163 \mathrm{cmbs}$ & & & 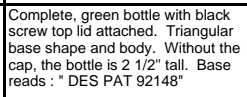 \\
\hline 8 & $8 \cdot 6$ & Milk glass-Cold cream jar & Glass & Grooming & 1 & 181 & Bag 8, Level 5, $143-163 \mathrm{cmbs}$ & \begin{tabular}{|} 
Chas. H. Phillips Company. \\
Phillips' cleansing cream
\end{tabular} & & 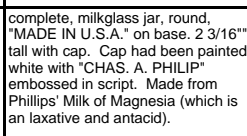 \\
\hline 8 & $8-7$ & Milk Glass saucer & Glass & Kitchen & 1 & 160 & Bag 8, Level 5, 143-163 cmbs & & & 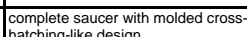 \\
\hline 8 & $8-8$ & Smaller Hi-lex bleach bottle & Glass & Activities & 1 & 803 & & \begin{tabular}{|l} 
Duraglas (1940+1)- Owens- \\
llinois (1929-9resent); Hi- \\
lex bleach
\end{tabular} & 1946 & 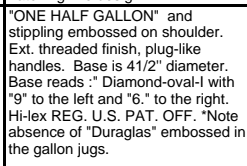 \\
\hline 8 & $8-9$ & \begin{tabular}{|l} 
Complete bottle-Root beer \\
flavoring
\end{tabular} & Glass & Kitchen & 1 & 102 & Bag 8, Level 5, 143-163 cmbs & 1900-present & & 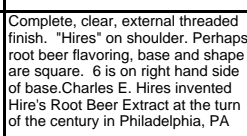 \\
\hline 8 & $8-10$ & \begin{tabular}{|l|} 
Milk of Magnesia frags-blue \\
glass
\end{tabular} & Glass & Medical & 1 & 142 & & 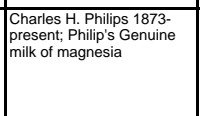 & & 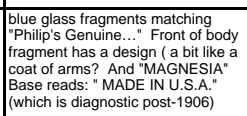 \\
\hline 8 & D & \begin{tabular}{|l} 
Tin can and small scraps of \\
metal
\end{tabular} & Metal & Kitchen & 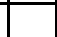 & 1588 & Bag 8, Level 5, 143-163 cmbs & & & \\
\hline 8 & D & \begin{tabular}{|l} 
Unknown metal strips with nails \\
an bolts
\end{tabular} & Metal & Unknown & $2^{2}$ & 213 & Bag 8, Level 5, 143-163 cmbs & & & \\
\hline 8 & D & Metal file & Metal & Tool & 1 & 372 & Bag 8, Level 5, 143-163 cmbs & & & \\
\hline 8 & D & Folgers Coffee Can Lid & Metal & Kitchen & 1 & 49 & Bag 8, Level 5, 143-163 cmbs & 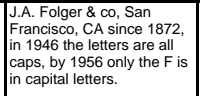 & & \\
\hline 8 & $\mathrm{D}$ & $\begin{array}{l}\text { tin can frag with maker's mark } \\
\text { on base }\end{array}$ & Metal & Kitchen & 1 & 43 & Bag 8, Level 5, 143-163 cmbs & \begin{tabular}{|l|}
$\begin{array}{l}\text { Possibly Canco 1930-1940 } \\
\text { (SW Arch. Field manual) }\end{array}$ \\
(Sw
\end{tabular} & & C in a circle \\
\hline 8 & D & Folgers Coffee can & Metal & Kitchen & 1 & 146 & Bag 8, Level 5, 143-163 cmbs & $\begin{array}{l}\text { J.A. Folger \& co, San } \\
\text { FFancisco, CA since } 1872, \\
\text { in } 1946 \text { the letters are all } \\
\text { caps, by 1956 only the Fis } \\
\text { in capital letters. }\end{array}$ & & \\
\hline 8 & D & Oil can lid & Metal & Transportation & 1 & 26 & Bag 8, Level 5, 143-163 cmbs & Gulf pride $10 / 10-W$ & & \\
\hline 8 & D & $\begin{array}{l}\begin{array}{l}\text { Rectangular metal can, } \\
\text { possibly meat can }\end{array} \\
\end{array}$ & Metal & Kitchen & 1 & 21 & Bag 8, Level 5, $143-163$ cmbs & & & $\begin{array}{l}23 / 8 \text { "Iong and too twisted for other } \\
\text { measurements, meat can was a } \\
\text { suggestions from John Clarke }\end{array}$ \\
\hline 8 & D & Texas License Plate & Metal & Transportation & 4 & 119 & Bag 8, Level 5, 143-163 cmbs & & & \\
\hline 8 & D & Folgers Coffee Can frag & Metal & Kitchen & 1 & 65 & Bag 8, Level 5, 143-163 cmbs & $\begin{array}{l}\text { J.A. Folger \& co, San } \\
\text { Francisco, CA since } 1872, \\
\text { in } 1946 \text { the leterters are all, } \\
\text { caps, by 1956 only the } \mathrm{F} \text { is } \\
\text { in capital letters. }\end{array}$ & & \\
\hline 8 & D & Tin can frag, & Metal & Kitchen & 1 & 45 & Bag 8, Level 5, $143-163 \mathrm{cmbs}$ & & & 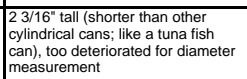 \\
\hline 8 & D & Motor oil can & Metal & Transportation & 2 & 30 & Bag 8, Level 5, 143-163 cmbs & Gulf pride 10/10-W & & \\
\hline 8 & D & \begin{tabular}{|l} 
Pulled wire nail \\
\end{tabular} & Metal & \begin{tabular}{|l|l|l} 
Architecture \\
\end{tabular} & 6 & 42 & Bag 8, Level 5, 143-163 cmbs & & & \\
\hline 8 & D & \begin{tabular}{|} 
Unknownnn fragment of metal \\
bar with thin wire attached
\end{tabular} & Metal & |Unknown & & 29 & Bag 8, Level 5, 143-163 cmbs & & & \\
\hline 8 & D & belt & Synthetic & Clothing & & 48 & Bag 8, Level 5, 143-163 cmbs & & & $\begin{array}{l}\text { white plastic with evenly spaced } \\
\text { holes make design on length of belt }\end{array}$ \\
\hline 8 & D & spool of thread & $\begin{array}{l}\text { Synthetic or } \\
\text { animal }\end{array}$ & Activities & 1 & 886 & Bag 8, Level 5, $143-163 \mathrm{cmbs}$ & & & \\
\hline 8 & ID & IScrap of sheet metal & Metal & Unknown & 1 & 310 & Bag 8, Level 5, 143-163 cmbs & & & \\
\hline
\end{tabular}




\section{Archeological Testing of the Engstrand Well 41WM1157, in Williamson County, Texas}

\begin{tabular}{|c|c|c|c|c|c|c|c|c|c|c|}
\hline Lot\# & \begin{tabular}{|l} 
Unique \\
Item \#
\end{tabular} & Item Description & Material type & \begin{tabular}{|l|l|}
$\begin{array}{l}\text { Functional } \\
\text { Category }\end{array}$ \\
Cate
\end{tabular} & QTY & $\mid$ WT (G) & Provenience & Maker's Mark - maker & Date of mark & Notes \\
\hline 8 & D & Ketchup bottle & Glass & Kitchen & 1 & 273 & Bag 8, Level 5, $143-163$ cmbs & $\begin{array}{l}\text { Owens-Illinois (1929- } \\
\text { present); Heinz Ketchup }\end{array}$ & $1937 ?$ & 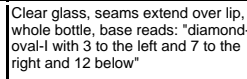 \\
\hline$\overline{8}$ & D & Ketchup bottle & Glass & Kitchen & & 300 & Bag 8, Level 5, 143-163 cmbs & \begin{tabular}{|l|} 
May wood glass co.; Heinz \\
Ketchup
\end{tabular} & $1930-1959$ & $\begin{array}{l}\text { Base reads: } 9580 \text { above logo (MG } \\
\text { combined) with } 47 \text { to the right and } \\
15 \text { below }\end{array}$ \\
\hline$\overline{8}$ & D & Ketchup bottle & Glass & Kitchen & & 307 & Bag 8, Level 5, 143-163 cmbs & 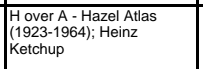 & & $\begin{array}{l}77406 \text { above logo (A in H) with } 7 \text { to } \\
\text { thight and } 0 \text { to the lower left and } \\
15 \text { to the lower right }\end{array}$ \\
\hline 8 & D & Ketchup bottle & Glass & Kitchen & 1 & 302 & Bag 8, Level 5, $143-163 \mathrm{cmbs}$ & \begin{tabular}{|l}
$\begin{array}{l}\text { Hover A-Hazel Atlas } \\
\text { (19923-19944); Heinz } \\
\text { Ketchup }\end{array}$ \\
\end{tabular} & & $\begin{array}{l}\text { Has someremaining paper label } \\
\text { Base reads: } 7406 \text { above logo }(\mathrm{A} \text { in } \\
\text { H) with } 7 \text { to the right and } 0 \text { to the } \\
\text { lower left and } 15 \text { to the lower right }\end{array}$ \\
\hline 8 & D & \begin{tabular}{|l|} 
Ketchup bottle \\
\end{tabular} & Glass & Kitchen & 1 & 270 & Bag 8, Level 5, 143-163 cmbs & 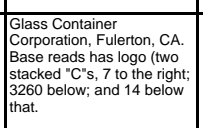 & & \begin{tabular}{|l|}
16 panelshbevels on the bottom hall \\
clear glass, whole bottle
\end{tabular} \\
\hline 8 & D & \begin{tabular}{|l|} 
Ketchup bottle \\
\end{tabular} & Glass & Kitchen & 1 & 273 & Bag 8, Level 5, $143-163 \mathrm{cmbs}$ & $\begin{array}{l}\text { Glass Containers Corp. } \\
\text { Base has double stacked } \\
\text { stylized "c" symbol with } \\
3260 \text { below }\end{array}$ & & 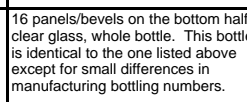 \\
\hline 8 & D & Ketchup bottle & Glass & Kitchen & 1 & 295 & Bag 8, Level 5, $143-163 \mathrm{cmbs}$ & 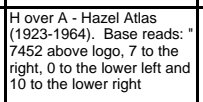 & & $\begin{array}{l}14 \text { panels or bevels run the length } \\
\text { of the bottle, more sloppining less } \\
\text { pronounced shoulders, circuar } \\
\text { shape, external threaded finish }\end{array}$ \\
\hline$\overline{8}$ & D & Ketchup bottle & Glass & Kitchen & & 289 & Bag 8, Level 5, 143-163 cmbs & 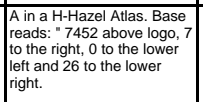 & & 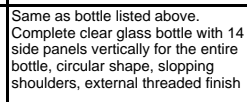 \\
\hline 8 & D & Vinegar bottle & Glass & Kitchen & & 443 & Bag 8, Level 5, 143-163 cmbs & base reads: $4625 ; 0$ & & 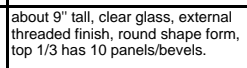 \\
\hline 8 & D & Vinegar bottle & Glass & Kitchen & 1 & 461 & Bag 8, Level 5, 143-163 cmbs & $\begin{array}{l}\text { FOSTER FORBES GLASS } \\
\text { CO., MARION, IN }\end{array}$ & $1942-2000$ & 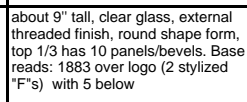 \\
\hline 8 & D & Vinegar bottle & Glass & Kitchen & 1 & 456 & Bag 8, Level 5, $143-163$ cmbs & \begin{tabular}{|l|} 
FOSTER FORBES GLASS \\
CO., MARION, IN
\end{tabular} & $1942-2000$ & 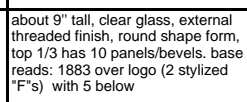 \\
\hline 8 & D & Vinegar bottle & Glass & Kitchen & & 470 & Bag 8, Level 5, 143-163 cmbs & C. H.B. & & 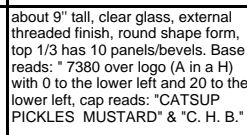 \\
\hline 8 & D & Vinegar bottle & Glass & Kitchen & 1 & 492 & Bag 8, Level 5, $143-163$ cmbs & $\begin{array}{l}\text { Hover A- Hazel Atlas } \\
(1923-1964)\end{array}$ & & 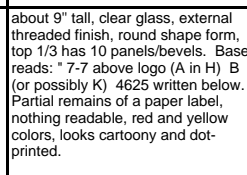 \\
\hline 8 & $\mathrm{D}$ & Vinegar bottle (Small) & Glass & Kitchen & & 283 & Bag 8, Level 5, 143-163 cmbs & $\begin{array}{l}\text { Ball Brothers Company } \\
\text { (11888-1996). Base eads } \\
180-16 \text { over logo (Ball in } \\
\text { script) }\end{array}$ & 1919-1969 & 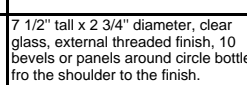 \\
\hline 8 & D & Vinegar bottle (Small) & Glass & Kitchen & & 291 & Bag 8, Level 5, 143-163 cmbs & $\begin{array}{l}\text { Hazel Atlas, base reads: " } \\
17-6 \text { over logo ( A in H) } 8 \\
\text { (or B or K) } 434 \text { written } \\
\text { below. Stippling present. }\end{array}$ & & $\begin{array}{l}71 / 2 " \text { tall } \times 23 / 4 " \text { "diameter, clear } \\
\text { glass, external threaded fininh, , } 10 \\
\text { bevels or panels around circle bottle } \\
\text { fro the shoulder to the finish. }\end{array}$ \\
\hline 8 & D & Vinegar bottle (Small) & Glass & Kitchen & & 294 & Bag 8, Level 5, $143-163$ cmbs & \begin{tabular}{|l|}
$\begin{array}{l}\text { naox Glasss Botlle co. } \\
\text { Jackson, Mississippi, } 9932-\end{array}$ \\
1953
\end{tabular} & & 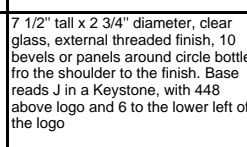 \\
\hline 8 & D & Vinegar bottle (Small) & Glass & Kitchen & & 296 & Bag 8, Level 5, 143-163 cmbs & $\begin{array}{l}\text { Hover A- Hazel Atlas } \\
(\text { (1923-1964) }\end{array}$ & & 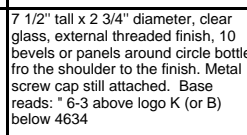 \\
\hline 8 & D & Vinegar bottle (Small) & Glass & Kitchen & $\overline{1}$ & 405 & Bag 8, Level 5, 143-163 cmbs & 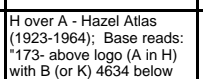 & & 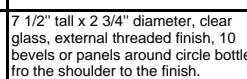 \\
\hline
\end{tabular}




\begin{tabular}{|c|c|c|c|c|c|c|c|c|c|c|}
\hline Lot\# & \begin{tabular}{|l} 
Unique \\
Item\#\#
\end{tabular} & |ltem Description & Material type & \begin{tabular}{|l} 
Functional \\
Catagory
\end{tabular} & QTY & WT (G) & Provenience & Maker's Mark - maker & Date of mark & Notes \\
\hline 8 & D & Canning Jar & Glass & |Kitchen & $\left.\right|^{2}$ & 666 & Bag 8, Level 5, $143-163$ cmbs & \begin{tabular}{|l|} 
Duragalas (1940+) - Owens- \\
llinois (1929-present)
\end{tabular} & 1947 & 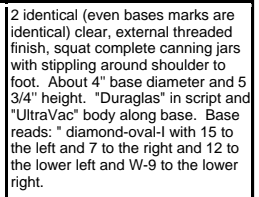 \\
\hline 8 & D & Canning jar & Glass & Kitchen & 1 & 184 & Bag 8, Level 5, 143-163 cmbs & \begin{tabular}{|l|} 
Duraglas (1940+) - Owens- \\
llinois (1929-present)
\end{tabular} & 1943 & 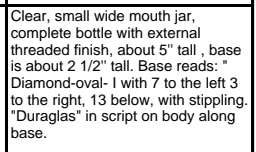 \\
\hline 8 & D & Canning Jar & Glass & Kitchen & 1 & 220 & Bag 8, Level 5, 143-163 cmbs & $\begin{array}{l}\text { Ball Brothers Company, } \\
\text { Muncie, IN }\end{array}$ & \begin{tabular}{|l|}
$1919-1969$ \\
\end{tabular} & 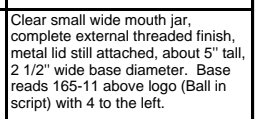 \\
\hline 8 & D & Canning Jar & Glass & Kitchen & 1 & 214 & Bag 8, Level 5, 143-163 cmbs & Hazel Atlas. & & 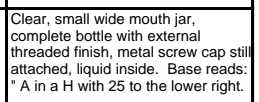 \\
\hline 8 & D & Canning jar (Tall) & Glass & Kitchen & 1 & 358 & Bag 8, Level 5, 143-163 cmbs & $\begin{array}{l}\begin{array}{l}\text { Hover A-Hazel Atlas } \\
(1923-1964)\end{array} \\
\end{array}$ & & 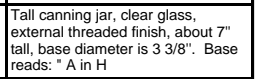 \\
\hline 8 & D & Preserve ware jar & Glass & Kitchen & 1 & 520 & Bag 8, Level 5, 143-163 cmbs & \begin{tabular}{|l}
$\begin{array}{l}\text { Hover A- Hazel Atlas } \\
(1923-1964)\end{array}$ \\
\end{tabular} & & 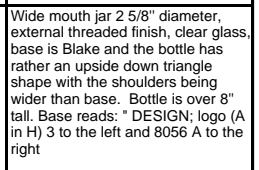 \\
\hline 8 & D & Pickle/ preserve ware & Glass & Kitchen & 1 & 238 & Bag 8, Level 5, 143-163 cmbs & $\begin{array}{l}\begin{array}{l}\text { Hover A- Hazel Atlas } \\
(1923-1964)\end{array} \\
\end{array}$ & & 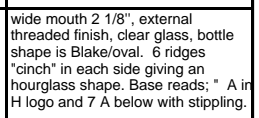 \\
\hline 8 & D & Mustard & Glass & Kitchen & 1 & 339 & Bag 8, Level 5, 143-163 cmbs & & & 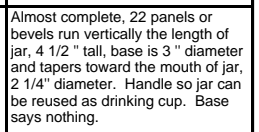 \\
\hline 8 & D & condiment bottle? & Glass & Kitchen & 1 & 280 & Bag 8, Level 5, $143-163 \mathrm{cmbs}$ & \begin{tabular}{|l|} 
Duraglas (1940+) - Owens- \\
llinois (1929-present)
\end{tabular} & 1947 & 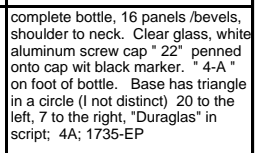 \\
\hline 8 & $D$ & mustard jar & & Kitchen & 1 & 339 & & & & 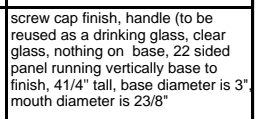 \\
\hline 8 & D & complete brown bottle & Glass & Kitchen & 1 & 275 & Bag 8, Level 5, $143-163$ cmbs & \begin{tabular}{|l|}
$\begin{array}{l}\text { Owens-Illinois (1929- } \\
\text { present) }\end{array}$ \\
\end{tabular} & 1933 & 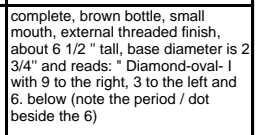 \\
\hline 8 & D & Medical bottle & Glass & Medical & 1 & 82 & Bag 8, Level 5, 143-163 cmbs & 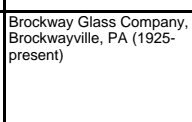 & & 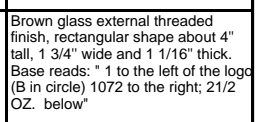 \\
\hline 8 & D & Medical bottle, cough syrup? & Glass & Medical & 1 & 74 & Bag 8, Level 5, 143-163 cmbs & \begin{tabular}{|l|}
$\begin{array}{l}\text { Duraglas (1940+) - Owens- } \\
\text { llinois (1929-present) }\end{array}$ \\
\end{tabular} & $1940+$ & \begin{tabular}{|l|} 
complete, clear, medical bottle with \\
graduated co's on the side, and \\
funny looking 3 followed by two \\
small cursive ii. "Duraglas and \\
diamond-oval-i a are on the base.
\end{tabular} \\
\hline 8 & D & complete bottle-cologne? & Glass & Grooming & 1 & 162 & Bag 8, Level 5, $143-163 \mathrm{cmbs}$ & & & 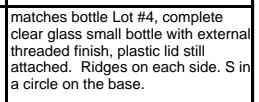 \\
\hline 8 & D & Milk glass & Glass & Grooming & 1 & 141 & Bag 8, Level 5, 143-163 cmbs & & & 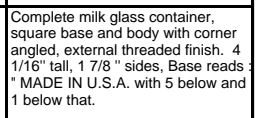 \\
\hline
\end{tabular}


54 Archeological Testing of the Engstrand Well 41WM1157, in Williamson County, Texas

\begin{tabular}{|c|c|c|c|c|c|c|c|c|c|c|}
\hline Lot\# & \begin{tabular}{|l} 
Unique \\
Item \#\#
\end{tabular} & Item Description & Material type & \begin{tabular}{|l|}
$\begin{array}{l}\text { Functional } \\
\text { Category }\end{array}$ \\
\end{tabular} & QTY & WT (G) & Provenience & Maker's Mark - maker & Date of mark & Notes \\
\hline 8 & D & Milk glass-Cold cream jar & Glass & Grooming & 1 & 181 & Bag 8, Level 5, 143-163 cmbs & $\begin{array}{l}\text { Chas. H. Phillips Company. } \\
\text { Phillips' cleansing cream }\end{array}$ & & 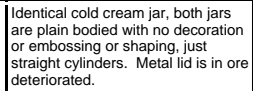 \\
\hline 8 & D & Milk glass frag & Glass & Grooming & 1 & 24 & Bag 8, Level 5, 143-163 cmbs & & & $\begin{array}{l}\text { Unknown grooming jar fragment. } \\
\text { Base reads: : P A A... NO NO } \\
12 . ; 94 . . . \text { Jar shows panel } \\
\text { indents as decorative elements. }\end{array}$ \\
\hline 8 & D & Hi-lex bleach bottle & Glass & Activities & 1 & 1424 & & \begin{tabular}{|l}
$\begin{array}{l}\text { Duraglas (1940+) - Owens- } \\
\text { Wilinois (1929-present) }\end{array}$ \\
\end{tabular} & 1946 & 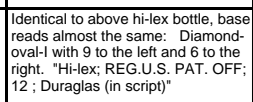 \\
\hline 8 & $\mathrm{D}$ & Unknown Bone & Animal & Dietary & 1 & 10 & & & & Burned \\
\hline 8 & $\mathrm{D}$ & White ware cup fragments & ceramic & Kitchen & 2 & 62 & & & & $\begin{array}{l}\text { geometric molded design along the } \\
\text { base. Matches fragments from } \\
\text { ther levels. }\end{array}$ \\
\hline 8 & D & Flower pot & ceramic & \begin{tabular}{|l} 
Household/ \\
Furniture
\end{tabular} & 2 & 89 & & & & \begin{tabular}{|l} 
thick whiteware with yellow/ beige \\
glaze with raised dreen netaves. \\
Matches fragments in ther levels
\end{tabular} \\
\hline$\overline{8}$ & D & Flower pot & ceramic & $\begin{array}{l}\begin{array}{l}\text { Household / } \\
\text { Furniture }\end{array} \\
\end{array}$ & 1 & 12 & & & & $\begin{array}{l}\text { bisque terra cotta, matches frags } \\
\text { from other levels }\end{array}$ \\
\hline 8 & D & Lid & synthetic & Kitchen & 1 & 1 & & Clorox & & \begin{tabular}{|l|} 
Brown plastic screw cap with \\
"CLOROX" on top
\end{tabular} \\
\hline 8 & D & ACL marked drinking glasses & 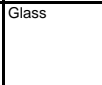 & Kitchen & 2 & 21 & & & & $\begin{array}{l}\text { ACL on clear glass fragments one is } \\
\text { a drinking glass with red and white } \\
\text { tlowers the other fragment tis too } \\
\text { faded and small to identify. }\end{array}$ \\
\hline 8 & D & Hi-lex bleach frags. & Glass & Activities & 9 & 53 & & \begin{tabular}{|l} 
Hi-lex, St. Paul, Minnesota. \\
Began in 1927 and ended \\
production in $1970 \mathrm{~s}$
\end{tabular} & & 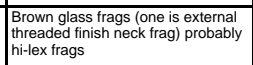 \\
\hline$\overline{8}$ & D & Hillex bleach bottle frags. & Glass & Activities & 2 & 25 & & $\begin{array}{l}\text { Hi-lex, St. Paul, Minnesota. } \\
\text { Began in } 1927 \text { and ended } \\
\text { production in } 1970 \mathrm{~s}\end{array}$ & & \\
\hline 8 & D & \begin{tabular}{|l|l|} 
Finish fragments -clear glass \\
Canning Jar
\end{tabular} & Glass & Kitchen & 7 & 276 & & & & $\begin{array}{l}\text { Clear glass, external threaded } \\
\text { finish, side seams extend over lip. }\end{array}$ \\
\hline 8 & D & Finish-Medical bottle & Glass & Medical & 1 & 17 & & & & $\begin{array}{l}\text { clear glass, botlle neck frag with "2 "2 } \\
\text { 1/2 oz" embossed, prescription-like } \\
\text { finish round body shape, side } \\
\text { seams over top. }\end{array}$ \\
\hline 8 & D & \begin{tabular}{|l}
$\begin{array}{l}\text { Finish clear glass bottle } \\
\text { fragments }\end{array}$ \\
font
\end{tabular} & Glass & Kitchen & 3 & 11 & & & & External threaded finishes \\
\hline 8 & D & Hi-lex bleach bottle & & Activities & 1 & 1304 & & $\begin{array}{l}\text { Duraglas (1940+) - Owens- } \\
\text { |linois (1929-present); Hi- } \\
\text { lex bleach }\end{array}$ & 1946 & 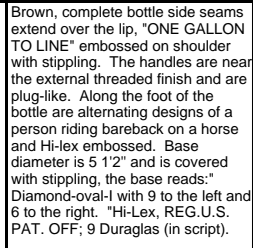 \\
\hline 8 & D & $\begin{array}{l}\text { Milk of Magnesia frags-blue } \\
\text { glass }\end{array}$ & & Medical & 2 & 23 & & $\begin{array}{l}\begin{array}{l}\text { Philip's Genuine milk of } \\
\text { magnesia }\end{array} \\
\text { meses }\end{array}$ & & smaller refit fragments of 8-10 \\
\hline 8 & D & \begin{tabular}{|l|} 
Base-clear glass bottle base \\
\end{tabular} & $\begin{array}{l}\text { Glass } \\
\end{array}$ & Kitchen & 1 & 82 & & \begin{tabular}{|l|}
$\begin{array}{l}\text { owens-Illinois (1929- } \\
\text { present) }\end{array}$ \\
\end{tabular} & 1937? & $\begin{array}{l}\text { Diamond-oval- with "2" to the left, } \\
\text { "7" to the right and "3" below }\end{array}$ \\
\hline 8 & D & Base-clear glass bottle base & Glass & Kitchen & 1 & 64 & & $\begin{array}{l}\text { Hover A-Hazel Atlas } \\
(1923-1964)\end{array}$ & & $\begin{array}{l}4625 \text { above the logo, A to the lower } \\
\text { left and } 4 \text { below, with stippling }\end{array}$ \\
\hline 8 & D & Base-clear glass bottle base & Glass & Kitchen & 1 & 50 & & $\begin{array}{l}\text { Owens-Illinois (1929- } \\
\text { present) }\end{array}$ & 1945 & $\begin{array}{l}\text { Diamond-oval-17 t t the leff, } 5 \text { to the } \\
\text { right, and } 6 \text { below, with stippling }\end{array}$ \\
\hline$\frac{8}{8}$ & $\mathrm{D}$ & \begin{tabular}{|l|} 
Base clear glass bottle \\
\end{tabular} & Glass & Kitchen & 1 & 80 & & Unknown & & Base reads : "....234; 11" \\
\hline 8 & D & Base-clear glass bottle & Glass & Kitchen & 1 & 79 & & & & base reads: " 20 " with stippling \\
\hline 8 & D & \begin{tabular}{|l|} 
Base-clear glass bottle \\
\end{tabular} & Glass & Kitchen & 1 & 75 & & $\begin{array}{l}\text { Jin a keystone - Knox } \\
\text { Bottle Co. (1932-1953). } \\
\text { Jacksonville, MS plant }\end{array}$ & 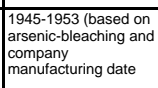 & $\begin{array}{l}\text { base reads: I in a keystone shape, } \\
\text { and } 292 \text { to the right. Bootle is oval } \\
\text { or rectangular shape }\end{array}$ \\
\hline 8 & D & Base- clear glass & Glass & Kitchen & 1 & 36 & & Owens-Illinois, Alton, IIII & 1948 & $\begin{array}{l}\text { Base reads: " DES PAT; } 94824 \\
\text { with Diamond-oval- with } 7 \text { to the left } \\
\text { and } 8 \text { of the right. Base shape is } \\
\text { irregular polygonn }\end{array}$ \\
\hline 8 & D & \begin{tabular}{|l} 
Finish-wide mouth clear glass \\
jars
\end{tabular} & $\begin{array}{l}\text { Glass } \\
\end{array}$ & Kitchen & 2 & 69 & & & & \begin{tabular}{|l|} 
External threaded wide mouth jar \\
with metal screw caps antached \\
on has unreadable red and white \\
lettering.
\end{tabular} \\
\hline 8 & D & \begin{tabular}{|l}
$\begin{array}{l}\text { Body fragments-clear glass } \\
\text { bottles }\end{array}$ \\
\end{tabular} & Glass & Kitchen & 69 & 632 & & & & $\begin{array}{l}3 \text { of these clearly have panels like a } \\
\text { ketchup bottle and 2 have shape/ } \\
\text { form like vinegar jars. }\end{array}$ \\
\hline
\end{tabular}


Appendix B

\section{Coordination Letters}





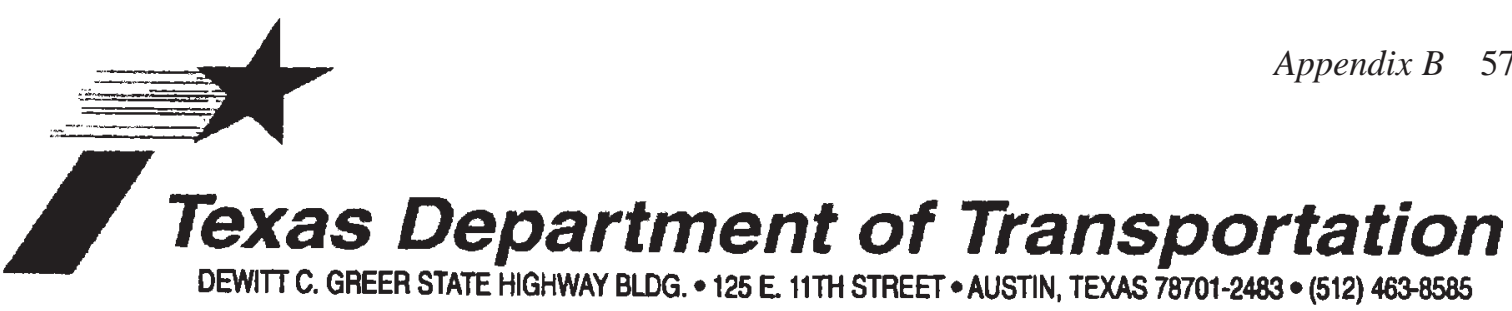

January 18,2007

RE: Transmittal of Hicks and Company Interim Report for NRHP Eligibility Testing of 41WM1 157: The Post Review Discovery of a Historical Stone Lined Well Located Immediately North of US 79 and 200 meters east of the Palm Valley Church Driveway Entrance in Williamson County: CSJ: 0204-01-049: Texas Antiquities Permit No. 4347

James E. Bruseth, Ph.D.

Division of Archeology, Texas Historical Commission

P.O. Box 12276

Austin, Texas 78711

Dear Dr. Bruseth:

In accord with the Programmatic Agreement (PA) among TxDOT, Federal Highways

Administration, the Advisory Council on Historic Preservation, and the Texas Historical Commission (THC), and the Memorandum of Understanding (MOU) between TxDOT and THC, we are continuing Section 106 and Antiquities Code consultation for this proposed undertaking.

This project entails widening the existing US 79 roadway between FM 1460 and CR 195 in Williamson County. Approximately 14 acres of new right-of-way is required. In 2002, TxDOT conducted an archeological assessment of the undertaking' $s$ area of potential effect. No archeological remains were identified. On September 9, 2002, the THC concurred with TxDOT's finding of "no historic properties affected". The project has been under construction since that consultation.

On November 27, 2007, the TxDOT Environmental Affairs Division was notified by the Austin District that a historical well had been uncovered near the northern US 79 shoulder approximately 0.33 miles east of the Palm Valley Church entrance driveway. TxDOT notified the THC in regard to this discovery via e-mail on November 27,2006. A TxDOT staff archeologist inspected the find and recommended an immediate archeological investigation in the form of National Register of Historic Places (NRHP) Eligibility Testing. The THC issued Texas Antiquities Permit No. 4347 to Hicks and Company to conduct the testing investigation.

From December 7 to 12,2006 , staff from Hicks and Company conducted the recommended NRHP eligibility testing for the historical well. The investigators recorded the well as 41WM1157 and completely excavated the well. On December 18, 2006, the THC concurred that the data potential of the well had been exhausted and that the excavation could be refilled (see attached letter).

Staff from Hicks and Company conducted an analysis of the artifacts recovered from their excavation. They also conducted archival research and informant interviews involving the property parcel on which the well is located. Based upon the relatively modern artifact assemblage dating

1

Transmittal of Hicks and Company Interim Report for NRHP Eligibility Testing of 41WM1157: The Post Review Discovery of a Historical Stone Lined Well Located Immediately North of US 79200 meters east of the Palm Valley Church Driveway Entrance in Williamson County: CSJ: 0204-01-049: Texas Antiquities Permit No. 4347 
from the early $1950^{\prime} \mathrm{s}$ as well as the lack of linkage of $41 \mathrm{WM} 157$ to individuals important to the historic development of the region, Hicks and company has recommended that the portion of 4IWM1157 located within the US 79 right-of-way is not eligible for listing in the NRHP. A copy of their interim report is attached for your review.

Based upon their findings, TxDOT agrees with the Hicks and Company recommendations and therefore seeks THC concurrence that the portion of 41WM1157 located within the US 79 right-ofway does not contribute to the site's eligibility for listing in the National Register of Historic Places and does not warrant designation as a State Archeological Landmark. Please signify your concurrence by signing on the signature line provided below. TxDOT will continue Texas Antiquities Code consultation with your office regarding the final testing report for 41WM1157 when it becomes available. If you have any questions, please contact me at 416-2640. Thank you for your consideration in this matter. Concurrence by; $\quad$ Joh Budd, TxDOT Staff Archeologist

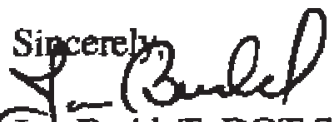
Concurrence by; $\quad$ Joh Budd, TxDOT Staff Archeologist For F. Lawerence Oaks, Stafe Ffstoric Preservation Officer and Executive Director

Attachments cc w/attachments: Austin District Office, ATTN: M. Walker, ENV-JAR, JHB; Reading File 
Dr. James Bruseth

Archeology Division Director

Texas Historical Commission

P.O. Box 12276

Austin, TX 78711-2276

Re: National Register Eligibility Testing of a Historic Well on US 79 CSJ\# 0204-01-049

\section{Attn: Mark Denton}

Dear Dr. Bruseth:

Hicks \& Company recently conducted emergency excavations of a historic well located along US79 in Palm Valley, Williamson County, Texas. The testing was conducted in advance of road widening under Section 106 of National Historic Preservation Act and the Texas Antiquities Code, Permit 4347. An interim coordination report was submitted on December 21, 2006, recommending that the well and its contents were not eligible for the National Register of Historic Places, since most of the material we recovered from the well was of 1940s vintage. Your office concurred with those recommendations on January 18, 2007. Hicks \& Company is currently in the process of conducting analysis of the artifacts and producing the final report. At present, we have several hundred pounds of artifacts salvaged from the well: Most of that material consists of metal scrap, bottle glass, non-diagnostic, or repetitive items. During conversations with TxDOT reviewers in December, we discussed the possibility of eventually

discarding most of this non-diagnostic material. This letter is intended to request on behalf of TxDOT a selective discard strategy that would allow us to reduce the total number of artifacts that ultimately are sent to TARL for curation. Types of artifacts that we would like to discard include:

- Non diagnostic ceramic fragments

- Window glass and unmarked bottle glass fragments

- Nails and screws

- Bricks or architectural material

- Metal scrap, pipes, and unmarked tin can fragments

- non-diagnostic machinery parts

- Plastic fragments

- Duplicate examples of saved items such as labeled cans, bottles, tools, plates, and personal items.

Saved artifacts would include examples of each diagnostic artifact type such as labeled tin cans (there are many Gulf Motor Oil cans, for instance), bottles, ceramic types, toys, types of personal items, bone, or anything of curiosity not commonly recorded. We anticipate that only about $10 \%$ of the total recovered assemblage will eventually be curated at TARL.

As part of the analysis we will catalog all of the artifacts we recovered. Therefore, we intend to produce a complete inventory of all material from the project. As there is great quantity of unidentifiable broken and brittle scrap metal, we will quantify this material by weight within each provenience, rather than count. The complete artifact inventory will accompany the curated items 


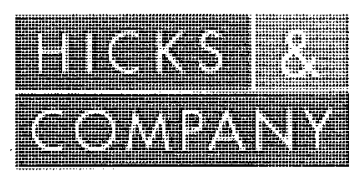

and will contain all recorded information about the artifacts that were discarded, as well as more specific information about the saved items. Our final report will state that diagnostic artifacts and records only will be curated. Please confirm that this is acceptable under the terms of our permit. Do not hesitate to call us at 512-478-0858 if there are any questions.

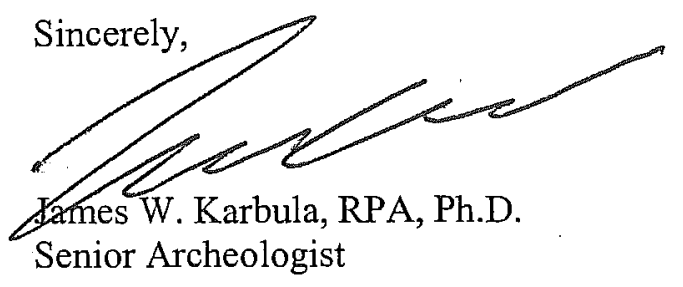

JK:rf

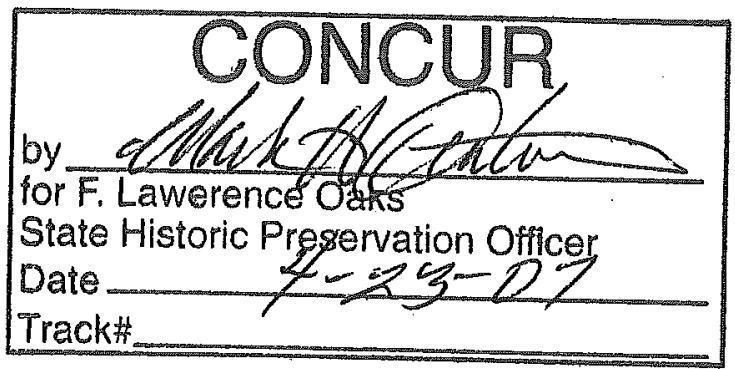



